\title{
A Method for Predicting Cracking in Waste Glass Canisters
}

D. W. Faletti

L. J. Ethridge

August 1986

Prepared for the U.S. Department of Energy under Contract DE-AC06-76RLO 1830

Pacific Northwest Laboratory Operated for the U.S. Department of Energy by Battelle Memorial Institute 


\title{
DISCLAIMER
}

This report was prepared as an account of work sponsored by an agency of the United States Government. Neither the United States Government nor any agency thereof, nor any of their employees, makes any warranty, express or implied, or assumes any legal liability or responsibility for the accuracy, completeness, or usefulness of any information, apparatus, product, or process disclosed, or represents that its use would not infringe privately owned rights. Reference herein to any specific commercial product, process, or service by trade name, trademark, manufacturer, or otherwise, does not necessarily constitute or imply its endorsement, recommendation, or favoring by the United States Government or any agency thereof. The views and opinions of authors expressed herein do nat necessarily state or reflect those of the United States Government or any agency thereof.

\author{
PACIFIC NORTHWEST LABORATORY \\ operated by \\ BATTELLE \\ for the \\ UNITED STATES DEPARTMENT OF ENERGY \\ under Contract DE-AC06-76RLO 1830
}

\begin{tabular}{|c|c|}
\hline \multirow{2}{*}{\multicolumn{2}{|c|}{ Printed in the United States of America }} \\
\hline & \\
\hline \multicolumn{2}{|c|}{$\begin{array}{l}\text { Available from } \\
\text { National Technical Information Service }\end{array}$} \\
\hline \multicolumn{2}{|c|}{$\begin{array}{l}\text { National Technical Information Service } \\
\text { United States Department of Commerce }\end{array}$} \\
\hline \multicolumn{2}{|c|}{5285 Port Royal Road } \\
\hline \multicolumn{2}{|c|}{ Springfield, Virginia 22161} \\
\hline \multirow{2}{*}{\multicolumn{2}{|c|}{$\begin{array}{l}\text { NTIS Price Codes } \\
\text { Microfiche } A 01\end{array}$}} \\
\hline & \\
\hline \multicolumn{2}{|c|}{ Printed Copy } \\
\hline & Price \\
\hline Pages & Codes \\
\hline $001-025$ & $\mathrm{~A} 02$ \\
\hline $026-050$ & $\mathrm{~A} 03$ \\
\hline $051-075$ & $\mathrm{~A} 04$ \\
\hline $076-100$ & A05 \\
\hline $101-125$ & A06 \\
\hline $126-150$ & $\mathrm{~A} 07$ \\
\hline $151-175$ & $\mathrm{~A} 08$ \\
\hline $176-200$ & A09 \\
\hline $201-225$ & $\wedge 010$ \\
\hline $226-250$ & A011 \\
\hline $251-275$ & A012 \\
\hline $276-300$ & A013 \\
\hline
\end{tabular}


A METHOD FOR PREDICTING CRACKING IN WASTE GLASS CANISTERS
D. H. Faletti
L. J. Ethridge

August 1986

Prepared for

the U.S. Department of Energy under Contract DE-ACO6-76RLO 1830

Pacific Northwest Laboratory

Richland, Washington 99352 


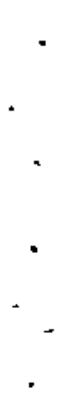


SUMMARY

The method being implemented in the IJnited States and abroad for long-term disposal of high-level radioactive waste is to incorporate the waste into glass. A liquid-fed ceramic melter is used to produce this waste glass and to pour it into metal canisters. However, the thermal gradients that occur during the canister filling and cooling process give rise to significant thermal and residual stresses in the glass. These stresses generaliy result in significant cracking of the glass in the canister. Considerable attention has been given to the reduction of cracking because cracks expose more surface area to leaching and can create fine particles that could pose an inhalation risk if the canister were breached in an accident. The purpose of this report is to summarize what is known about cracking in canisters, to provide information on a recent study of canister cracking completed at Pacific Northwest Laboratory (PNL), to present a correlation that predicts crack surface area to within the accuracy of the available data, and to give some perspective on the role of cracking in radionuclide release.

The amount of quantitative cracking information for particle size data from which cracking area can be inferred) from canisters with known thermal histories was found to be very limited. Sixteen such canisters have been examined in this and four previous studies. The canisters ranged in diameter from 15 to $60 \mathrm{~cm}$ and in length from 80 to $290 \mathrm{~cm}$. Cooling conditions ranged from very slow (phased cooling using an annealing oven) to very rapid (the canister was immersed in water during and after filling). The canisters were made of either carbon steel or stainless steel. Three of the canisters with known cracked areas (two from this study) were lined with fiberfrax ceramic paper. Reported values of the relative surface areas (the ratio of the total surface area of the glass to the surface area of a glass monolith) ranged from 1 to 48 .

Fiberfrax, a ceramic paper, has been proposed as a canister lining in order to alleviate thermal stresses in the glass during filling, cooldown, and

(a) Fiberfrax - Carborundum Co., Niagara Falls, New York. 
decontamination of the canisters, as well as to reduce glass-canister interactions. In this study, eight lined canisters were filled. All eight were then sectioned radially and longitudinally to obtain qualitative information cn the cracking within. Two were dismantled following estimation of the crack area by use of a crack-intersect fiduciary line technique. The reiative area ratios for these canisters were smal1, 3.5 and 7 . Of particular significance was that no fines were observed and that there was no visible change in the Fiberfrax. Thermocouples that were placed within the glass did not increase localized cracking.

A simple linear relationship, hetween the relative surface area (defined as the ratio of the total glass surface area to that of a crack-free glass monolith) and the radial temperature difference within the glass when its surface temperature was $500^{\circ} \mathrm{C}$, was found to correlate the available data to within experimental uncertainties. This correlation was extrapolated to heatproducing radioactive canisters by using the difference between the radial temperature difference when the centerline of the canister was at $500^{\circ} \mathrm{C}$ and the steady-state radial temperature difference. The resulting correlation, applicable to both radioactive and nonradioactive canisters, was

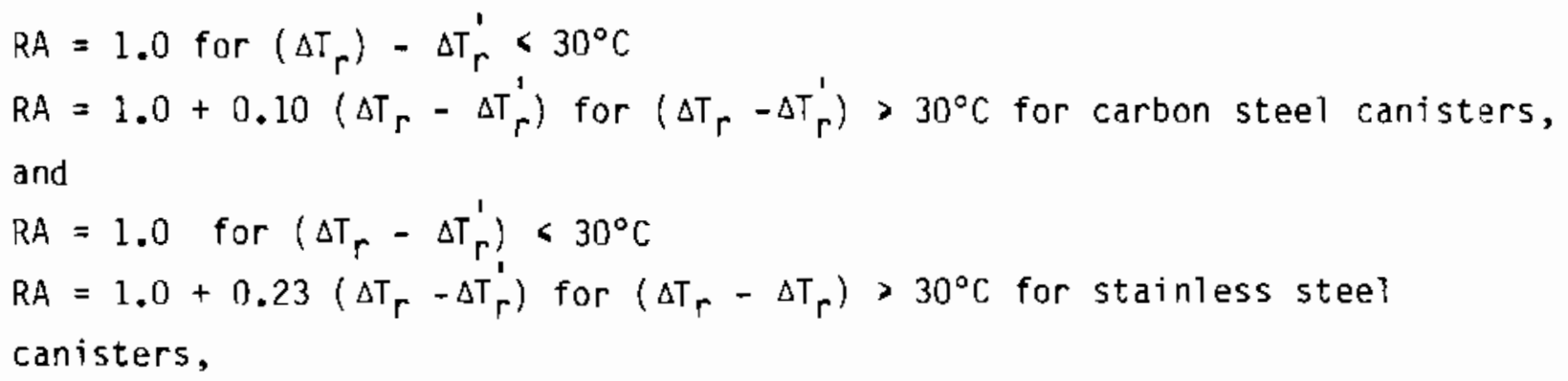

where: RA is the relative surface area, dimensionless

$\Delta T_{r}$ is the radial temperature difference when the canister centerline is at $500^{\circ} \mathrm{C}$

$\Delta T_{r}^{\prime}$ is the steady-state radial temperature difference.

The basis for this correlation was that according to the "quick-freeze" model, residual stresses occur in the glass if the radial temperature difference changes from that which existed when the glass passed through the transition temperature. Any subsequent change in temperature distribution following cooldown below the transition temperature (generally between $500^{\circ} \mathrm{C}$ 
and $550^{\circ} \mathrm{C}$ for waste glasses) will result in stresses that can cause cracking. Therefore, the radial temperature difference when the centerline temperature reached $500^{\circ} \mathrm{C}$ was chosen as a measure of the magnitude of these locked-in stresses for nonradioactive canisters. For cases where the radial temperature difference is nonzero because of internal heat decay, it is appropriate to use the difference between $\Delta T_{r}$ and the steady-state radial temperature difference.

Although the correlation is useful for scoping purposes, there is a need to validate it against additional canister cracking data, particularly in the case of stainless steel canisters. Recommendations for such studies are made in Section 6.0 of this report.

The use of Fiberfrax iiners deserves serious consideration for stainless steel waste glass canisters. The amount of cracking appears to he reduced because the liner eliminates the metal-glass interactions that produce significant stresses in the glass. Another advantage of using Fiberfrax, less obvious but very important, is that thermal shocking (and thereby additional cracking) during decontamination and post-fill operations would be reduced hecause of the liner's insulating capacity. More extensive studies to verify these results are also recommended in Section 6.0 . 


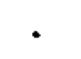

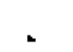

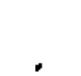

, 


\section{ACXNOWLEDGMENTS}

The authors would like to acknowledge Charlie A. Church for his valuable assistance in cutting and dismantling the canisters and providing many of the photographs published in this report. The authors are also indebted to Naomi Sherer and Suzanne Liebetrau for their help in the preparation of the manuscript. 
.

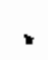

, 


\section{CONTENTS}

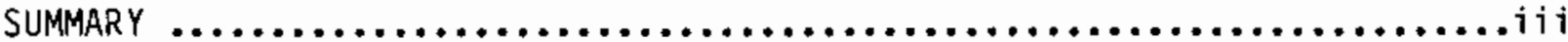

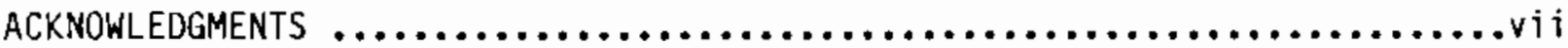

1.0 INTRODUCTION $\ldots \ldots \ldots \ldots \ldots \ldots \ldots \ldots \ldots \ldots \ldots \ldots \ldots \ldots \ldots \ldots \ldots \ldots \ldots \ldots \ldots \ldots$

2.0 BACKGROUND AND PREVIOUS STUdIES $\ldots \ldots \ldots \ldots \ldots \ldots \ldots \ldots \ldots \ldots \ldots \ldots \ldots \ldots$

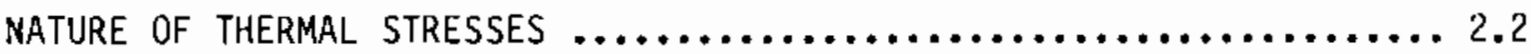

REVIEW OF CURRENT KNOWLEDGE $\ldots \ldots \ldots \ldots \ldots \ldots \ldots \ldots \ldots \ldots \ldots \ldots \ldots \ldots \ldots \ldots \ldots$

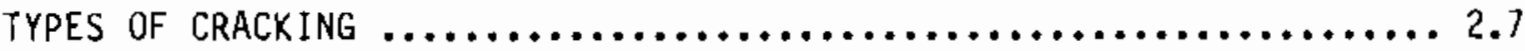

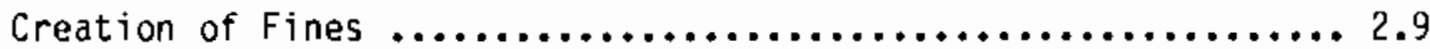

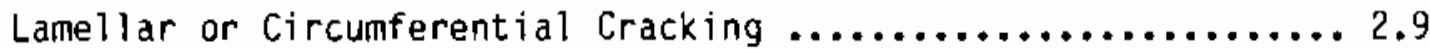

Bulk Cracking .................................... 2.10

GENERAL INFORMATION ON CRACKING AND PARTICLE SIZE............. 2.10

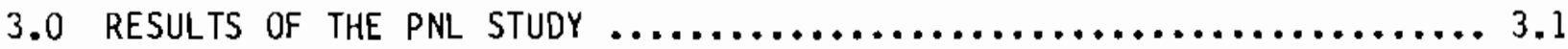

ESTIMATES BY FIDUCIARY LINE METHOD $\ldots \ldots \ldots \ldots \ldots \ldots \ldots \ldots \ldots \ldots \ldots \ldots . \ldots \ldots$

ESTIMATES BY PARTICLE EXAMINATION $\ldots \ldots \ldots \ldots \ldots \ldots \ldots \ldots \ldots \ldots \ldots \ldots . . \ldots \ldots$

COMPARISON OF METHODS FOR ESTIMATING SURFACE AREAS $\ldots \ldots \ldots \ldots \ldots \ldots . \ldots . \ldots$

4.0 METhOD FOR ESTIMATING EXTENT OF CRACXING $\ldots \ldots \ldots \ldots \ldots \ldots \ldots \ldots \ldots \ldots \ldots . \ldots$

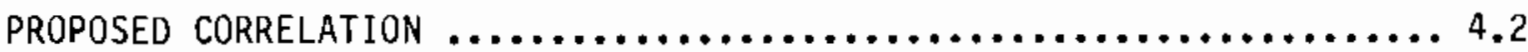

Relative Surface Area $\ldots \ldots \ldots \ldots \ldots \ldots \ldots \ldots \ldots \ldots \ldots \ldots \ldots \ldots . \ldots . \ldots . \ldots \ldots$

Surface Area from Particle Size Distribution .............. 4.6

Reference Temperature............................ 4.7

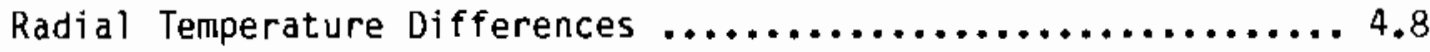

AGREEMENT BETWEEN CORRELATION AND DATA $\ldots \ldots \ldots \ldots \ldots \ldots \ldots \ldots \ldots \ldots \ldots . \ldots$

Unlined Canisters Exposed to Unchanging Cooling Conditions ..... 4.10

Fiberfrax-Lined Canisters ......................... 4.13 
Application of Correlation to Changing Cooling Conditions ..... 4.15

5.0 DISCUSSION $\ldots \ldots \ldots \ldots \ldots \ldots \ldots \ldots \ldots \ldots \ldots \ldots \ldots \ldots \ldots \ldots \ldots \ldots \ldots \ldots \ldots \ldots \ldots$

APPLICATION OF CORRELATION TO HIGH-DECAY HEAT GLASSES $\ldots \ldots \ldots \ldots \ldots \ldots . . . .2$

FUTURE CRACKING STUDIES $\ldots \ldots \ldots \ldots \ldots \ldots \ldots \ldots \ldots \ldots \ldots \ldots \ldots \ldots \ldots \ldots \ldots$

EFFECTS OF CRACKING ON RADIONUCLIDE RELEASE $\ldots \ldots \ldots \ldots \ldots \ldots \ldots \ldots \ldots . \ldots \ldots$

6.0 CONCLUSIONS AND RECOMMENDATIONS $\ldots \ldots \ldots \ldots \ldots \ldots \ldots \ldots \ldots \ldots \ldots \ldots \ldots \ldots \ldots \ldots$

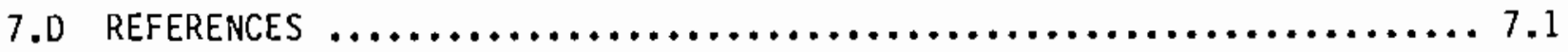

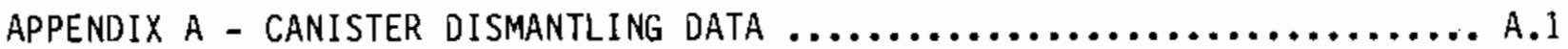

APPENDIX B - PHOTOGRAPHS OF CANISTERS $\ldots \ldots \ldots \ldots \ldots \ldots \ldots \ldots \ldots \ldots \ldots \ldots \ldots \ldots$ 


\section{FIGURES}

2.1 Radial Temperature Profiles During Cooldown .................. 2.4

2.2 Cross Section of Canister PS $-60-3,100 \mathrm{~cm}$ from Bottom ........... 2.8

2.3 Circumferential and Axial Relative Areas in Three Canisters

Subjected to Different Cooling Regimens as a Function of

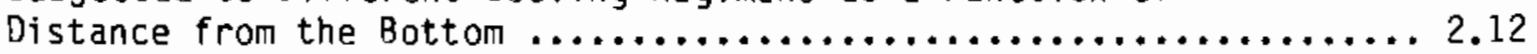

2.4 Particle Size Distribution $\ldots \ldots \ldots \ldots \ldots \ldots \ldots \ldots \ldots \ldots \ldots \ldots \ldots \ldots \ldots \ldots \ldots$

2.5 Effect of Cooling Time on Relative Surface Area of Thermal Cracks in Canisters $17 \mathrm{~cm}$ and $60 \mathrm{~cm}$ in Diameter $\ldots \ldots \ldots \ldots \ldots \ldots \ldots \ldots . . . \ldots \ldots$

3.1 Cross Section of $30.5-\mathrm{cm}$ Diameter Canisters $\ldots \ldots \ldots \ldots \ldots \ldots \ldots \ldots . . \ldots$

3.2 Circumferential Cracking Assumptions $\ldots \ldots \ldots \ldots \ldots \ldots \ldots \ldots \ldots \ldots$

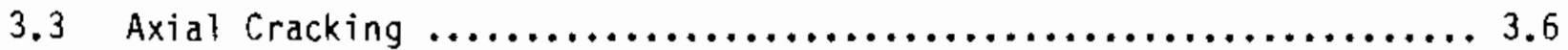

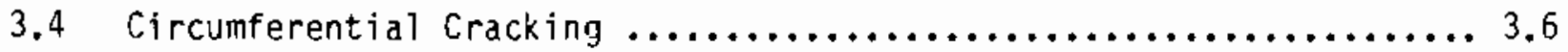

3.5 Canister \#2 Spherical Burst, Indicated by Arrows $\ldots \ldots \ldots \ldots \ldots \ldots .7$

3.6 Canister \#2 Spherical Burst, Indicated by Arrows .............. 3.8

3.7 Cumulative Axial Crack Area as a Function of Canister Radius ....... 3.9

3.8 Cumulative Circumferential Crack Area as a Function of Distance from Canister Centerline ............................. 3.10

3.9 Glass Pieces from the Top and Bottom of Canister $\# 2 \ldots \ldots \ldots \ldots \ldots . . \ldots 31$

3.10 Glass Pieces from the Top and Bottom of Canister $\# 7 \ldots \ldots \ldots \ldots \ldots . . . .12$

4.1 Correlation Between Relative Surface Area and Radial

Temperature Difference at $500^{\circ} \mathrm{C}$ Centerline Temperature .......... 4.3

4.2 Radial Cross Section of Canister \#3 of Peters and Slate $1981 \ldots \ldots .4 .6$

4.3 Comparison of Fibrafrax-Lined Canister with Correlation .........4.9

4.4 Results Obtained from Changing Cooling Conditions ............. 4.14

4.5 Centerline and Wall Temperatures During Muitistaged Cooldown ...... 4.18 
4.6 Comparison of Centerline Wall Temperature Differences

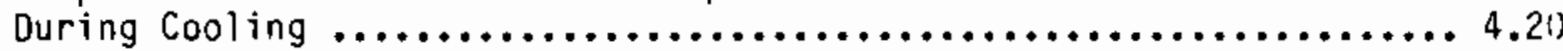

4.7 Computed Radial Temperature Distribution of Canister

FCS-15-2 at Commencement of Water Quenching $\ldots \ldots \ldots \ldots \ldots \ldots \ldots \ldots \ldots .2$.

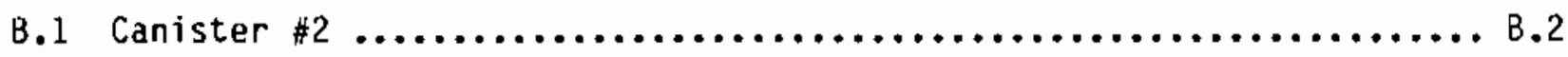

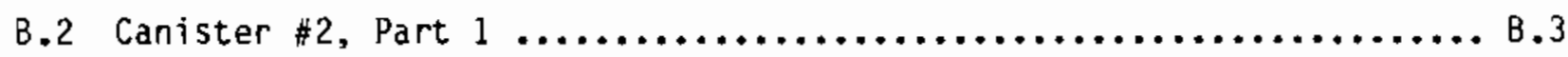

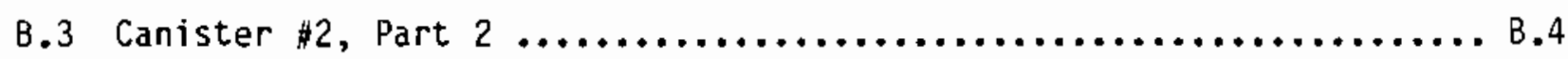

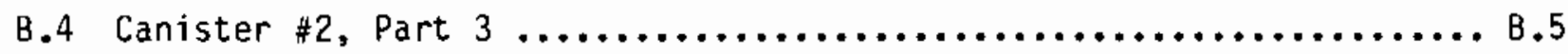

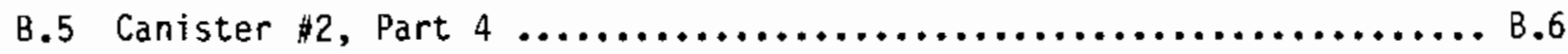

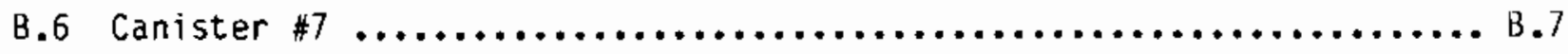

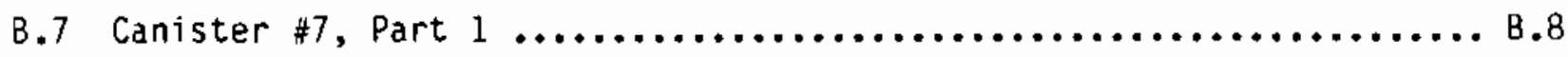

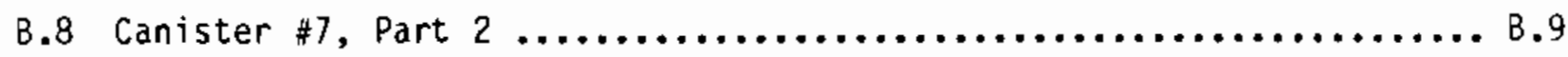

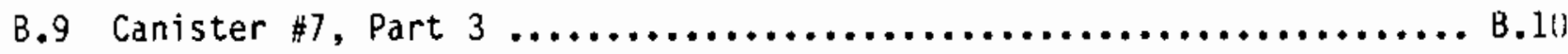

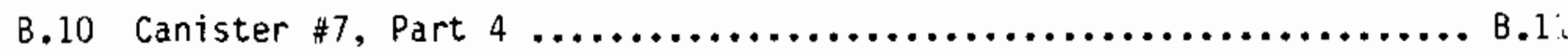

B.11 Canister $\# 1$.............................................. B.

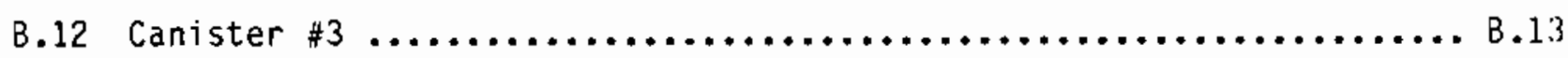

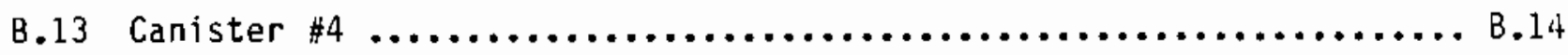

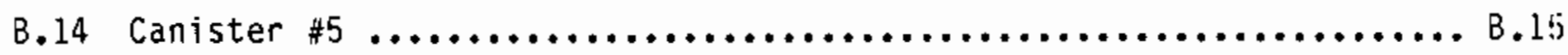

B.15 Canister $\# 6$............................................ B.16

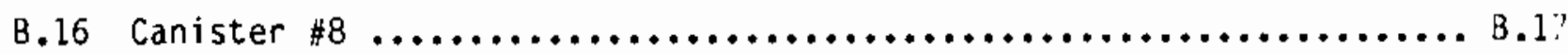

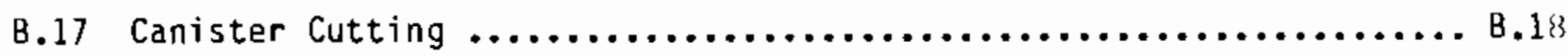

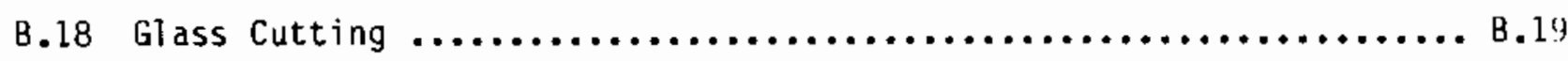




\section{TABLES}

2.1 Summary of Known Canister Cracking Data $\ldots \ldots \ldots \ldots \ldots \ldots \ldots \ldots \ldots \ldots$

3.1 Surface Area Estimates from Fiduciary Line Measurements ......... 3.5

3.2 Surface Area Estimates from Glass Particle Sizes ...................

3.3 Summary of the Surface Area Techniques $\ldots \ldots \ldots \ldots \ldots \ldots \ldots \ldots \ldots . \ldots \ldots$

4.1 Surmary of All Available Data ........................ 4.4

4.2 Estimates of Relative Surface Areas from Particle Size of

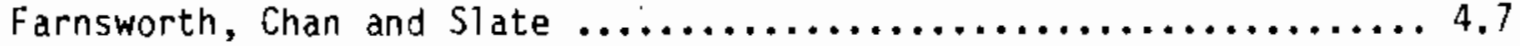

4.3 Comparison of the Surface Area Techniques $\ldots . \ldots \ldots \ldots \ldots \ldots \ldots \ldots . \ldots . \ldots 11$

A.1 Canister 2, Top Quarter Glass Particle Distribution ...............2

A.2 Canister 2, Bottom Quarter Glass Particle Distribution .............3

A.3 Canister 7 , Top Quarter Glass Particle Distribution ..............4

A.4 Canister 7, Bottom Quarter Glass Particle Distribution ............5

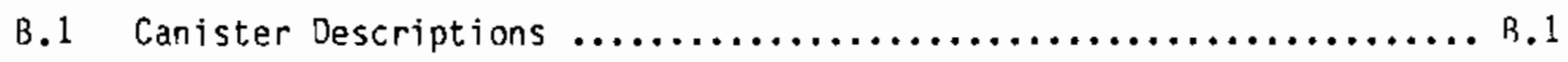




\subsection{INTRONUCTION}

The liquid-fed ceramic melter (LFCM) is being implemented in the United States and abroad for the production of waste forms in metal canisters for long-term disposal of high-level radioactive wastes. In this process the radioactive liquid waste is mixed with glass formers and fed to a melter where it is heated to form a chemically stable glass. This glass is poured into canisters, which can range from 30 to $60 \mathrm{~cm}$ in diameter and from 1 to $3 \mathrm{~m}$ in height. The thermal gradients that occur during the canister filling and cooling process give rise to significant thermal and residual stresses in the glass as it solidifies and cools. Considerable attention has been given to the reduction of cracking, because cracks expose more surface area to leaching and can create fine particles. Although Perez and Westsik (1981) found leaching from pressurized cracks to be only a fraction of that from external surfaces, some uncertainties still remain in expected releases from real canisters. Excessive glass fines (defined as particles smaller than $1 \mathrm{~mm}$ in diameter) are a concern in both transportation and repository operations because of the potential hazards of dispersion and inhalation if the canister is breached. Finally, there is the possibility that cracking could impede heat transfer within the glass, causing increased steady-state centerline temperatures with high-heat-loading waste forms.

This report summarizes what is known about cracking in canisters, provides information from a recent study of canister cracking completed at Pacific Northwest Laboratory ( $P N L$ ), presents a method for estimating crack surface area as a function of thermal history, and gives some perspective on the consideration of cracking in determining an effective waste form size.

Section 2.0 provides a background for understanding the causes of cracking and provides a review of the literature. The available data on cracking and on particle size distributions in glass from canisters produced in the LFCM are also presented. 
Section 3.0 presents the results of a study conducted at PNL in which Fiberfrax ${ }^{\oplus}$ ceramic paper was used as a liner between the glass and the canister.

Section 4.0 presents a correlation for predicting the amount of cracking. This correlation is based on the radial temperature difference occurring when the glass is near the transition temperature.

Section 5.0 contains a discussion of the findings of this study and attempts to place cracking into perspective.

Section 6.0 presents conclusions and recommendations for further studies.

Trademark of Carborundum Co., Niagara Falls, New York. 


\subsection{BACKGROUND AND PREVIOUS STUOIES}

The changing temperature fields in waste glass canisters during cooling result in stress buildups that generally cause the glass to crack. Studies have been conducted that have provided much useful information on the extent and causes of this cracking. Although attempts were made to obtain as much quantitative information as possible, much of what is known must be viewed as qualitative in nature. This is because the problem of cracking is both experimentally and theoretically complex.

The problem is experimentally complex for a variety of reasons. First, experiments that isolate the effects of variables on cracking are difficult to conduct. For example, the extent of glass cracking is dependent upon the timetemperature history that the canister experiences. In order to compare the effects of canister material, two canisters would have to be poured under identical conditions, which is very difficult under existing melter procedures.

Another problem is related to dismantling a canister in order to examine the glass within. The procedure is expensive. Furthermore, an unknown amount of cracking takes place during the dismantling process. In addition to the increased cracking that may occur when stresses are applied to pry glass pieces apart, additional cracking could occur as the canister is cut apart (canisters normally exert a compressive load on the glass within) and/or the glass is disassembled, because of the change in the stress distribution within the canister.

The theory of thermal stresses is well developed for cases where the stresses remain low enough that the strength of the glass is not exceeded (a)though the limitations of thermal computation methods restrict the use of even this theory). However, for those cases where the fracture strength of the glass is exceeded, no accurate mathematical technique exists for predicting the location and extent of cracking. First, the time-temperature field must be predicted accurately and in almost microscopic detail before and following the onset of cracking. However, cracking may affect heat transfer and hence the temperature field within the glass. Second, crack initiation and propagation must be predicted in the same detail. Crack initiation and propagation in glass is a stochastic process; thus, mechanistic models are not practical. 
NATURE OF THERMAL STRESSES

Before discussing the relevant studies, a brief background on the nature of thermal stresses is presented. First consider thermal stresses in glass that is well below its transition temperature, where it behaves as a solid. If we consider a stress-free cylinder, initially at $T_{0}$, to which heat is applied, the temperature of the cylinder will increase. A temperature gradient will occur, with the higher temperatures near the outer surfaces and cooler temperatures near the center. Greater expansion will occur in the hotter material near the surface than in the cooler material near the center. However, the resulting differential expansion (for example, in the axial direction) will be restrained to meet the condition of no exterior forces on the canister. As a result, the outer regions of the cylinder will be under axial compressive stress, whereas the inner surfaces will be under axial tensile stress. If the strains are too small to create permanent deformation, the stresses will disappear as soon as the cylinder becomes isothermal again. Cooling an initially stress-free, isothermal cylinder will result in stresses of the opposite sign, $i . e$. , tensile stresses near the surface and compressive stresses near the center. For a thorough review of such stresses, including derivations of equations for thermal stresses, refer to Timoshenko (1962). The equations for an infinitely long cylinder showing the effects of coefficient of expansion, temperature distribution and other variables are given below:

$$
\begin{gathered}
\sigma_{r}=\frac{a \mathbb{E}}{1-v}\left(\frac{1}{b^{2}} \int_{0}^{b} \operatorname{Tr} d r-\frac{1}{r^{2}} \int_{0}^{r} \operatorname{Tr} d r\right) \\
\sigma_{\theta}=\frac{a E}{1-v}\left(\frac{1}{b^{2}} \int_{0}^{b} \operatorname{Tr} d r+\frac{1}{r^{2}} \int_{0}^{r} \operatorname{Tr} d r-T\right) \\
\sigma_{x}=\frac{a f}{1-v}\left(\frac{2}{b^{2}} \int_{0}^{b} \operatorname{Tr} d r-T\right)
\end{gathered}
$$




$$
\text { where } \begin{aligned}
\sigma_{r} & =\text { radial stress }-\mathrm{N} / \mathrm{m}^{2} \\
\sigma_{\theta} & =\text { tangential stress }-\mathrm{N} / \mathrm{m}^{2} \\
\sigma_{\mathrm{x}} & =\text { axial stress }-\mathrm{N} / \mathrm{m}^{2} \\
a & =\text { coefficient of thermal expansion }-\mathrm{m} / \mathrm{m}-{ }^{\circ} \mathrm{C} \\
\mathrm{b} & =\text { radius of cylinder }-\mathrm{m} \\
\mathrm{E} & =\text { modulus of elasticity }-\mathrm{N} / \mathrm{m}^{2} \\
\nu & =\text { Poissons ratio - dimensionless } \\
\Gamma & =\text { distance from centerline }-\mathrm{m} \\
T & =\text { temperature }-{ }^{\circ} \mathrm{C} .
\end{aligned}
$$

Stresses are also set up by the changes in volume that take place during and after the glass solidification. Since glass is an amorphous material, a true phase change does not take place; i.e., there is no definite temperature at which the solid changes to liquid. The volume change for glass upon "solidification" is dependent to some extent upon the rate of temperature drop at the solidification region. Thus the problem is made even more complicated. Other effects include the formation of voids in regions undergoing tensile stress. Martin (1985) has attempted a solution that takes all these effects into account.

One method of dealing with stresses arising from the solidification of glass is to use the "quick-freeze" model. In this model the glass is assumed to be liquid until it reaches the transition temperature, whereupon it takes on the properties of a solid. A number of versions exist (see Martin 1985 for a discussion); the argument presented below (Tooley 1974) uses the quick freeze model from and suffices for the purpose of this study.

The quick-freeze model is illustrated with the aid of Figure 2.1, which shows radial temperature profiles that are qualitatively similar to what would exist inside a canister during the cooldown process. The typical waste glasses produced by LFCMS have transition temperatures of about $510^{\circ} \mathrm{C}$. Above the transition temperature the glass does not have the ability to retain stresses. Thus, although a temperature gradient exists for temperature profile \#l, no stresses exist. The same is true for profile \#2, although the outer portions of the glass are below $510^{\circ} \mathrm{C}$, if one assumes that no stress buildup occurs in 


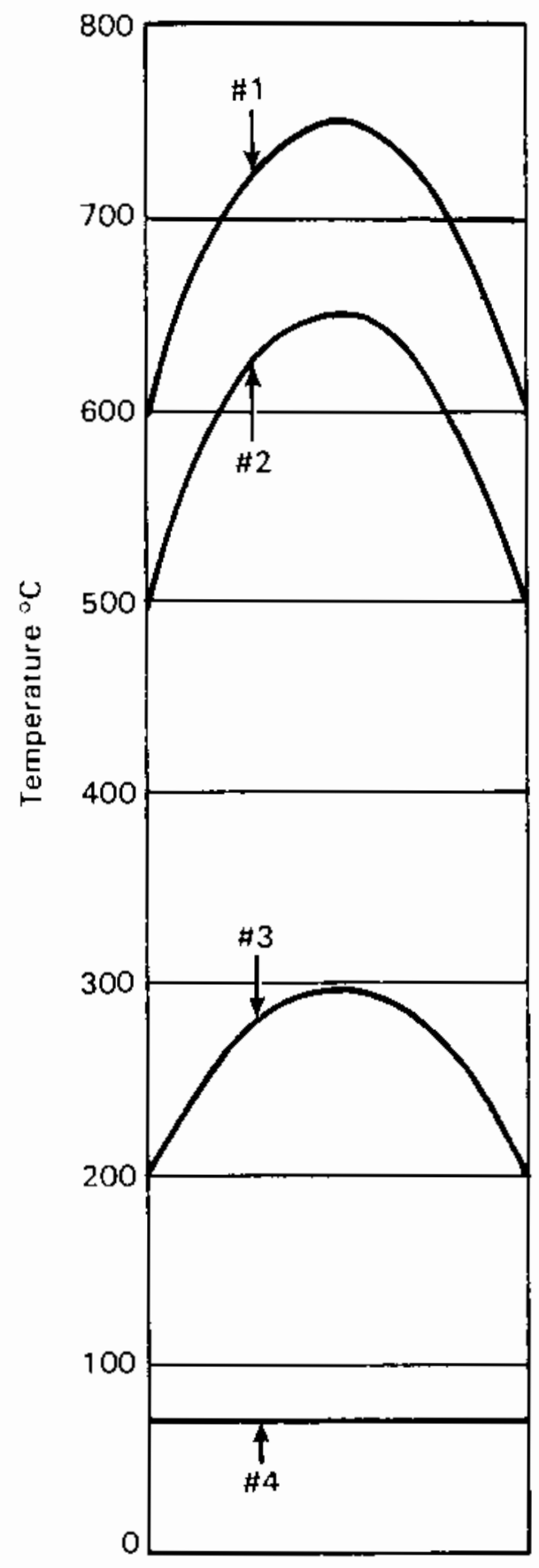

FIGURE 2.1. Radial Temperature Profiles During Cooldown 
the glass as the temperature of the glass passes through the transition temperature. The implication is that liquid glass is available to flow into the freeze front to make up for volume reductions upon freezing, or that the volume reduction is negligible. Although this assumption is true only for extremely slow cooling, the approximation gives acceptable results for the glass industry (Tooley 1974), as will be shown in this report, and is applicable to cracking in waste glass canisters.

Even if the glass is stress free at the transition temperature, "permanent" stresses will build up if the temperature gradient changes after the glass has cooled below the transition temperature. The stresses occur because the regions that experienced a larger change in temperature relative to neighboring regions will have shrunk more than regions with smaller temperature changes, thereby setting up strains and corresponding stresses in the glass. For example, consider the case where the glass eventually cools to room temperature (profile \#4). If profile \#2 is used as the zero stress reference profile, the glass on the centerline of the canister will have cooled $580^{\circ} \mathrm{C}$ (i.e., from $650^{\circ} \mathrm{C}$ to $70^{\circ} \mathrm{C}$ ). However, the material at the edge will have cooled only $430^{\circ} \mathrm{C}$ (i.e., from $500^{\circ} \mathrm{C}$ to $70^{\circ} \mathrm{C}$ ). No region in the glass is free to change dimensions independently of any other region. Thus the $150^{\circ} \mathrm{C}$ difference in temperature drop that the glass experiences $\left(580^{\circ} \mathrm{C}\right.$ versus $\left.430^{\circ} \mathrm{C}\right)$ will cause the glass in the middle to be stretched, and thereby to be under tensile stress, while the glass at the outside surface will be under compression in order to maintain an internal force balance. Cracking occurs if these stresses exceed the strength of the glass.

The permanent stresses are expected to be less for a radioactive glass where volumetric heating occurs. For a given temperature profile at the transition temperature, a radioactive glass will experience a smaller change in radial temperature difference than a nonradioactive glass cooled in the same manner. This can best be seen by comparing profile \#2 and profile \#3 of Figure 2.1, where profile $\# 3$ is taken to be the steady-state temperature profile of the radioactive canister. Here, for illustrative purposes, we assume that radioactive heat production and the heat transfer from the canister is such that at steady state, the canister centerline temperature is $300^{\circ} \mathrm{C}$ and the 
canister wall temperature is $200^{\circ} \mathrm{C}$. The lower radial temperature difference of profile \#3, compared to profile $\$ 2$, results from lower heat transfer to ambient because of decreased temperature driving force when the canister is at steady state. The change in radial temperature difference between profiles \#2 and \#3 is significantly less than that between profile \#2 and profile \#4, because of the radioactive heat release that results in a $100^{\circ} \mathrm{C}$ radial temperature difference at steady state. Thus, instead of the $150^{\circ} \mathrm{C}$ temperature difference in centerline to glass surface temperature between profile $\$ 2$ and profile \#4, only a $50^{\circ} \mathrm{C}$ change in centerline to surface temperature difference occurs. Thus the radioactive glass would initially experience lower permanent stresses for a given temperature profile at the transition temperature. Oniy as the radioactive materials have decayed over time will the permanent stresses approach that of the nonradioactive canister. This process will take a hundred years, during which time significant stress relief from creep may have taken place.

There are other effects of the cooling schedule. If the rate of cooling is increased after all the glass has passed through the transition temperature, then the temperature profile will become steeper than profile \#2 of Figure 2.1 . The glass will develop "thermal" stresses of the type described earlier for an initially isothemal canister. However, in this case, the thermal stresses will depend upon the change in the temperature profile from that existing when the glass passed through the transition temperature (profile \#2), not the temperature profile alone as described by the equations given earlier. In this way the quick-freeze model ties together the transition temperature effects with the effects of changes in temperature distribution after temperatures have fallen below the transition temperature. Applications of this model to canisters for cases of steady and nonsteady cooling conditions are presented in Section 4.0 .

Although the simplified picture given above ignores effects of stress relaxation after freezing, void formation, and other events (which can be included, see Martin 1985), it should provide sufficient background for the purposes of understanding the following review of current knowiedge. 


\section{REVIEW OF CURRENT KNOWLEDGE}

Only a limited number of publications exist that give substantial information on cracking in full-size canisters. These include: Slate et al. (1978); Peters and Slate (1981); Smith and Wiley (1980); Smith and Baxter (1981); Farnsworth, Chan and Slate (1984); Kahl (1985); and Martin (1985).

Papers by Laude, Vernaz and Saint'Gaudens (1982) supply some information on cracking in full-size canisters but do not provide enough background material to allow analysis of the results.

Kamizono and Senoo (1983) and Kamizono and Niwa (1984) studied the fracture behavior as a function of initial glass temperature by dropping glass cylinders ( $25 \mathrm{~cm}$ diameter by $25 \mathrm{~cm}$ long) into water. These experiments subjected the glass to thermal stresses but did not simulate stresses imposed during the glass solidification process. Furthermore, the sample dimensions are far from those of full-size canisters.

Simonen and Slate (1979) present the results of computer stress computations for canisters and the stresses within them.

The extent and characteristics of cracking observed in canisters have been found to be dependent upon the following variables:

- rate of cooldown or method of cooling (air cooled, insulated, water quenched or annealed)

- canister material (coefficient of thermal expansion, degree of canister/glass adhesion)

- use of coatings or liners on the interior surface of the canister (prevents bonding and/or eliminates stresses from the canister).

The extent and characteristics of cracking have not been studied in relation to the composition of the glass or the number of bubbles and of crack nuclei in the glass.

\section{TYPES OF CRACKING}

Figure 2.2 shows a cross section of a $60-\mathrm{cm}$ casting that was cooled by forced air cooling. The forced-air cooling was not initiated until the 


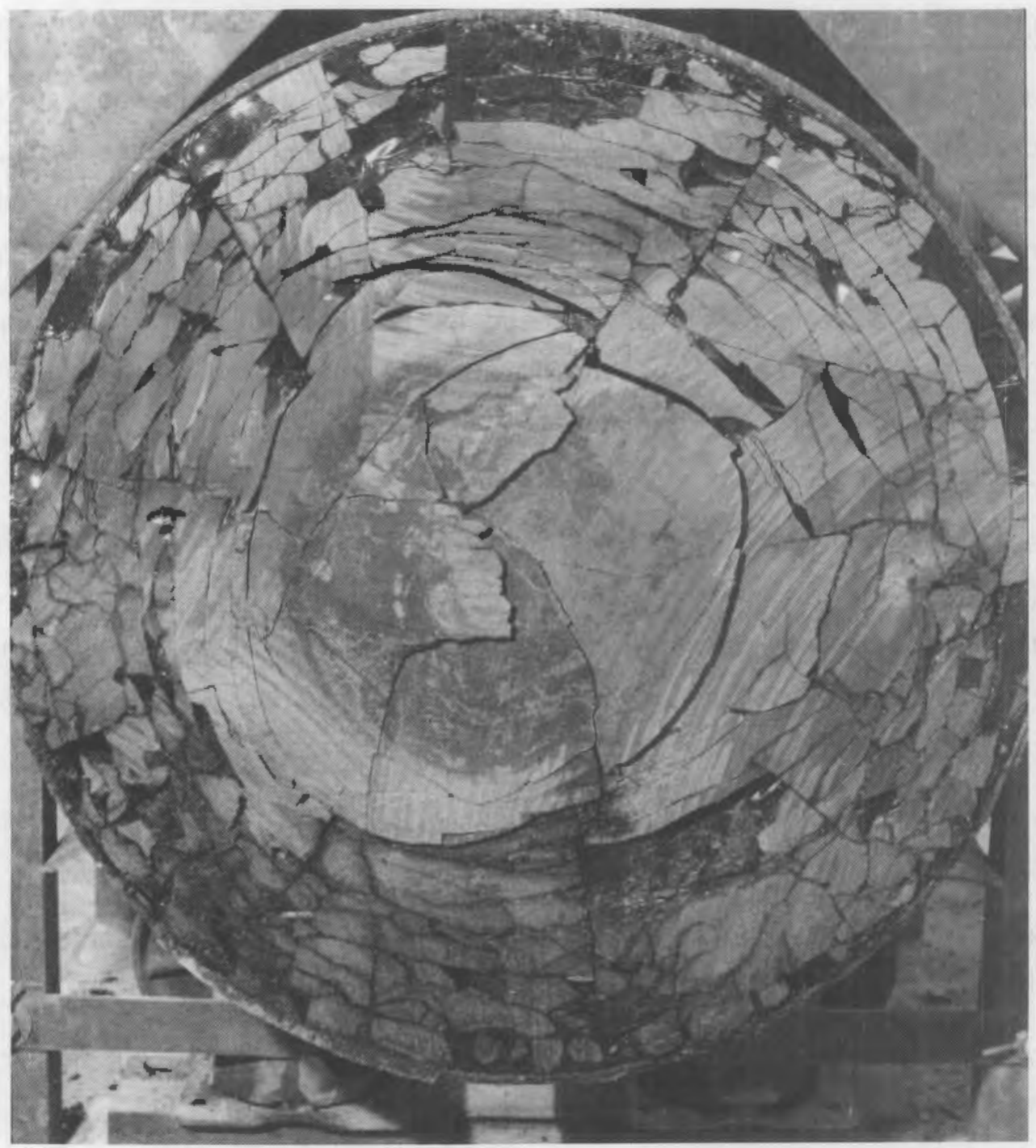

FIGURE 2.2. Cross Section (60-cm diameter) of Canister PS-60-3, $100 \mathrm{~cm}$ from Bottom

centerline temperature had fallen to $450^{\circ} \mathrm{C}$. The nature of the cracking shown is typical of that observed to a greater or lesser extent in any air-cooled uninsulated canister. (a) Cracking can be divided into three types: creation of fine particles (fines), lamellar cracking and bulk cracking.

(a) One of the few known cases of a crack-free canister, a 15-cm canister cooled over a period of several days, has been noted by slate et al. (1978). 


\section{Creation of Fines}

Fines are usually created at any glass-metal interface. They are believed to be caused by stresses imposed on the glass during cooling that are due to significant canister-glass interactions. These particles are extremely small, less than a millimeter in size. They are usually produced within about a centimeter of the glass/canister interface. There is evidence that they are the result of glass-canister interactions; for example:

- The amount of fines produced is greatest for canister materials that have a higher coefficient of thermal expansion than glass and least for materials that have a lower coefficient of thermal expansion than glass.

- The amount of fines produced increases if there is bonding between the canister and the glass. The use of bond-release agents such as graphite (which reduces shear stresses between the glass and the canister) greatly reduces fines production.

- Visual examinations indicate that fines are essentially eliminated by use of Fiberfrax liner on the inside of the canister, which acts to eliminate all canister-induced stresses.

Simonen conducted computer stress computations that show crack evolution from glass-canister interactions and glass-fin interactions that predict failure of the glass in shear (Simonen and Slate 1979; Slate et al. 1978). Although these computations do not take into account crack propagation theory or failures from compressive or tensile stresses, they do give qualitatively similar crack predictions. Lamellar or Circumferential Cracking

Lamellar cracking is caused by a combination of compressive stress placed upon the glass by the canister and by thermal stresses in the glass resulting from nonisothermal conditions during solidification and cooldown. The stresses imposed by the canister do not dominate lamellar cracking, as they do in fines production. 
The impression of crack area given by looking at a radial cross section is misleading because the cracks generally do not proceed into the glass in a straight line. Even pieces that are sheets or blocks will have one or more knife edges. Thus, a significant component of the surface area produced by lamellar cracking is in the plane perpendicular to the long axis of the cylinder. In some cases the cracks seem to lie more or less symmetrically around a central point, forming a spherical burst. An example of such a burst is shown later in Figure 3.5. A radial section taken within certain regions of this burst would give the incorrect impression that circumferential cracks have little or no radial or axial components. It should also be noted that the apparent spherical symmetry of the cracks surrounding the center of a spherica burst is misleading; the cracks often have significant radial and axial components.

Bulk Cracking

The term "bulk cracking" is applied to cracking that forms irregular, but large, pieces of glass that have roughly equal sizes in all dimensions. This cracking generally occurs most often in the inner half of the canister. It is thought to be the result of cracking resulting from thermal stresses where the temperature differences have been relatively small.

GENERAL INFORMATION ON CRACKING AND PARTICLE SIZE

The three classes of cracking described above are simplified but useful in describing the findings of the contributors mentioned here. Section 3.0 describes a case where canisters lined with ceramic insulation were cooled relatively slowly. During the dismantling of these canisters, it was not uncommon to find that a lamellar-type crack near the canister centerline would bend outward and extend all the way to the canister surface. If the cut portion was near a knife edge of the piece of glass it bounded, the visible portion of this crack might be only a fraction of a centimeter away from adjacent cracks, even though the piece of glass that the crack bounded might have dimensions on the order of $15 \mathrm{~cm}$ or larger.

The crack pattern existing upon completion of cooling may differ markedly from that observed after the canister has been cut to study the cracking. This 
change in crack pattern can cause an overestimation of the amount of cracking and a misinterpretation of the types of cracking that existed after cooldown. Residual stresses will certainly exist in the canister; these stresses are three dimensional in nature. Even radial cutting, which probably does the least to create additional cracking, eliminates any longitudinal stresses on the cutting plane. The resulting redistribution of stresses would be expected to produce further cracking. Longitudinal cutting, which eliminates radial and hoop stresses on the cutting plane, would be expected to promote even greater post-cool cracking. It is conceivable that spherical bursts such those shown later in Figure 3.5 could be the result of the axial cutting of the canister. Studies are badly needed in which canisters are subjected to nondestructive examinations for cracking, then dismantled to determine how much cracking is caused by the dismantling process. Gamma ray tomography is a promising technique for doing this (Reimers and Goebbels 1982; Reimers, Gilboy and Goebbeis 1984).

The sawing process also causes additional cracking; the sawblade places forces upon the glass. Shock or vibration of the canisters before and after cutting causes additional cracking and opening of crack interfaces. The "snaps and pops" heard when canisters are handled attest to their sensitivity to shock and vibration. Additional breakage will occur during handling to separate the convoluted pieces of glass, and further breakage will occur if the pieces are sifted and sieved.

The surface area measurements, based upon only radial measurements, may underestimate the amount of cracking significantly. For instance, Martin's (1985) results show an axial area component (the component of crack area perpendicular to the canister axis) that is equal in size to that of the radial component (the component of crack area perpendicular to the radial axis) for lamellar cracking (Figure 2.3). Thus, if the surface area is obtained by assuming that the lines of a radial cross section remain parallel to the long axis throughout the length of the cylinder, a significant underestimation in crack area could result. However, the cracking that occurs during disassembly will give the examiner an erroneously high estimation of the amount of cracking. 

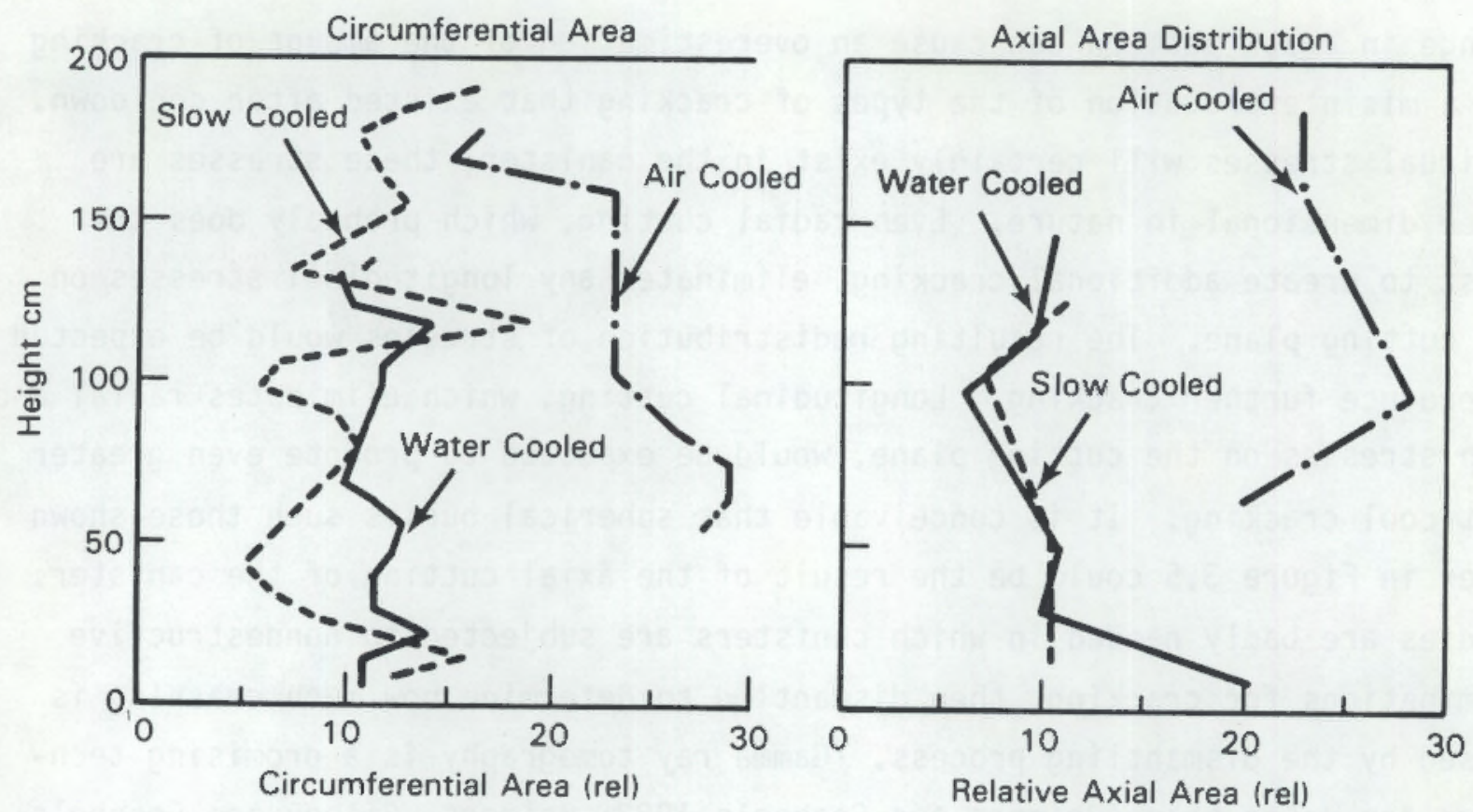

FIGURE 2.3. Circumferential and Axial Relative Areas (from Martin 1985 in Three Canisters Subjected to Different Cooling Regimens as a Function of Distance from the Bottom

Table 2.1 presents information on crack surface area and on glass particle sizes for all canisters that have known thermal histories. In addition to four studies found in the literature, information is given on the canisters described in Section 3.0 for comparison. Canister diameter varies from $17 \mathrm{~cm}$ to $60 \mathrm{~cm}$. Carbon steel, stainless steel and Fiberfrax-lined stainless steel canisters are included. Cooling schemes range from relatively slow (heavily insulated in still air) to fast (the glass being poured while the canister is immersed in water). Relative surface area, RA, defined as the sum of the surface area of the cracks, Ac, plus the surface area of a glass monolith, Am, divided by the surface area of the glass monolith ranges from unity to 48 :

$$
R A=\frac{A c+A m}{A m}
$$




\section{TABLE 2.1. Summary of Known Canister Cracking Data}

\begin{tabular}{|c|c|c|c|c|c|c|c|c|c|}
\hline Study & $\begin{array}{l}\text { Canister : } \\
\text { Original } \\
\text { Source }\end{array}$ & $\begin{array}{c}\frac{\text { Designation }}{\text { this }} \\
\text { Study } \\
\end{array}$ & $\begin{array}{c}\text { Diameter } \\
\mathrm{cm}\end{array}$ & $\begin{array}{l}\text { Length } \\
\mathrm{Cm} \\
\end{array}$ & $\begin{array}{l}\text { Canister } \\
\text { Material }\end{array}$ & Cooling History & $\begin{array}{c}\text { Relative } \\
\text { Surface Area } \\
\text { Source } \\
\end{array}$ & $\begin{array}{l}\text { Method } \\
\text { Used For } \\
\text { Relative } \\
\text { Surface Area } \\
\end{array}$ & $\begin{array}{l}\text { Particle } \\
\text { Size } \\
\text { Data } \\
\end{array}$ \\
\hline \multirow[t]{7}{*}{$\begin{array}{l}\text { Peters and } \\
\text { Slate } 1981\end{array}$} & 144 & PS-60-1 & 60 & 290 & $\begin{array}{l}\text { carbon } \\
\text { steel }\end{array}$ & $\begin{array}{l}\text { slow cooled in double } \\
\text { enclosure }\end{array}$ & 7 & radial section & none \\
\hline & 151 & PS-60-2 & 60 & 290 & $\begin{array}{l}\text { carbon } \\
\text { steel }\end{array}$ & $\begin{array}{l}\text { cooled in single } \\
\text { enclosure }\end{array}$ & 18 & radial section & none \\
\hline & 209 & PS-60-3 & 60 & 290 & $\begin{array}{l}\text { carbon } \\
\text { steel }\end{array}$ & $\begin{array}{l}\text { forced air in single } \\
\text { enclosure after some } \\
\text { cooling (at } 15 \mathrm{H} \text { ) }\end{array}$ & 17 & radial section & none \\
\hline & 1 & PS-17-1 & 17 & 80 & $\begin{array}{l}\text { carbon } \\
\text { steel }\end{array}$ & $5 \mathrm{~cm}$ insulation & 1 & radial section & none \\
\hline & 2 & PS-17-2 & 17 & 80 & $\begin{array}{l}\text { carbon } \\
\text { steel }\end{array}$ & $2.5 \mathrm{~cm}$ insulation & 3 & radial section & none \\
\hline & 3 & PS-17-3 & 17 & 80 & $\begin{array}{l}\text { carbon } \\
\text { steel }\end{array}$ & no insulation & 12 & radial section & none \\
\hline & 4 & PS $-17-4$ & 17 & 80 & $\begin{array}{l}\text { carbon } \\
\text { steel }\end{array}$ & nultistage cooling & 4 & radial section & none \\
\hline \multirow{2}{*}{$\begin{array}{l}\text { Farnsworth, } \\
\text { Chan and } \\
\text { slate 1984 }\end{array}$} & 1 & FCS-15-1 & 15 & 100 & $\begin{array}{l}\text { carbon } \\
\text { steel }\end{array}$ & ambient air & no & none & yes \\
\hline & 3 & FC:5-15-2 & 15 & 100 & $\begin{array}{l}\text { carbon } \\
\text { steel }\end{array}$ & $\begin{array}{l}\text { water quenched } \\
\text { when surface } \\
\text { temperature } \\
\text { reached } 350^{\circ} \mathrm{C}\end{array}$ & no & none & yes \\
\hline $\begin{array}{l}\text { Farnswarth, } \\
\text { Chan and } \\
\text { Slate } 1984\end{array}$ & $4 A$ & FCS-15-3 & 15 & 100 & $\begin{array}{l}\text { stainless } \\
\text { steel }\end{array}$ & $\begin{array}{l}\text { water quenched } \\
\text { when surface } \\
\text { temperature } \\
\text { reached } 350^{\circ} \mathrm{C}\end{array}$ & no & none & yes \\
\hline \multirow[t]{3}{*}{$\begin{array}{l}\text { Martin } \\
19 \times 5\end{array}$} & $A C$ & $M-30-1$ & 30 & 213 & $\begin{array}{l}\text { stainless } \\
\text { steei }\end{array}$ & dir cooled & 48 & $\begin{array}{l}\text { lungitudinal } \\
\text { section }\end{array}$ & no \\
\hline & WQ & $M-30-2$ & 30 & 213 & $\begin{array}{l}\text { stainiess } \\
\text { steel }\end{array}$ & water yuenches & 25 & $\begin{array}{l}\text { lonyitudinal } \\
\text { section }\end{array}$ & no \\
\hline & Ins & $M-30-3$ & 30 & 213 & $\begin{array}{l}\text { stainless } \\
\text { steel }\end{array}$ & insulated & 22 & $\begin{array}{l}\text { lonyitudinal } \\
\text { section }\end{array}$ & no \\
\hline $\begin{array}{l}\text { Kanl } \\
1985\end{array}$ & PIV/22 & $k-1$ & 30 & 80 & $\begin{array}{l}\text { stainless } \\
\text { steel \& } \\
\text { fiberfrax }\end{array}$ & $\begin{array}{l}3 \mathrm{hr} \text { cool down followed } \\
\text { by } 24 \mathrm{hr} \text { soak at } 550^{\circ} \mathrm{C} \\
\text { followed by } 6 \text { day } \mathrm{cool} \\
\text { down to ambient }\end{array}$ & 1.1 & & no \\
\hline $\begin{array}{l}\text { Thts } \\
\text { Study }\end{array}$ & $\begin{array}{l}\text { canister } \\
2 \\
\text { PSCH-20 }\end{array}$ & $F F-1$ & 30 & 98 & $\begin{array}{l}\text { stainless } \\
\text { steel \& } \\
\text { Fiberfrax }\end{array}$ & 1/4. in. insulation & 7 & $\begin{array}{l}\text { longitudinal } \\
\text { section }\end{array}$ & yes \\
\hline $\begin{array}{l}\text { This } \\
\text { Study }\end{array}$ & $\begin{array}{l}\text { Canister } \\
7 \\
\text { PSCM-20 }\end{array}$ & $F F-2$ & 30 & 98 & $\begin{array}{l}\text { stainless } \\
\text { steel } \\
\text { Fiberf rax }\end{array}$ & 3. in. insulation & 3.5 & $\begin{array}{l}\text { lonyitudinal } \\
\text { section }\end{array}$ & yes \\
\hline
\end{tabular}

Surface areas were determined by a number of methods. These include:

- adding up the length of lines on a radial section and multiplying by the length of the glass $\mathrm{log}$, assuming that the crack pattern is unchanged for the length of the canister (Peters and Slate 1981). 
- counting the number of crack crossings on fiduciary lines on the surface of a cut made lengthwise down the center of the canister (Martin 1985, see also Section 3.0).

- wrapping the glass pieces with aluminum foil and obtaining the surface area from the weight of aluminum foil required (Kahl 1985).

Farnsworth, Chan and Slate (1984) did not measure surface area but provided information on particle size distribution; this information is shown on Figure 2.4. Estimates of surface area were made from this particle size information and will be discussed in Section 5.0.

Peters and S1ate (1981) correlated relative surface area to cooling time as shown on Figure 2.5. This correlation is limited in that the effect of intermediate diameters can only be estimated; the correlation presented in Section 4.0 eliminates that limitation.

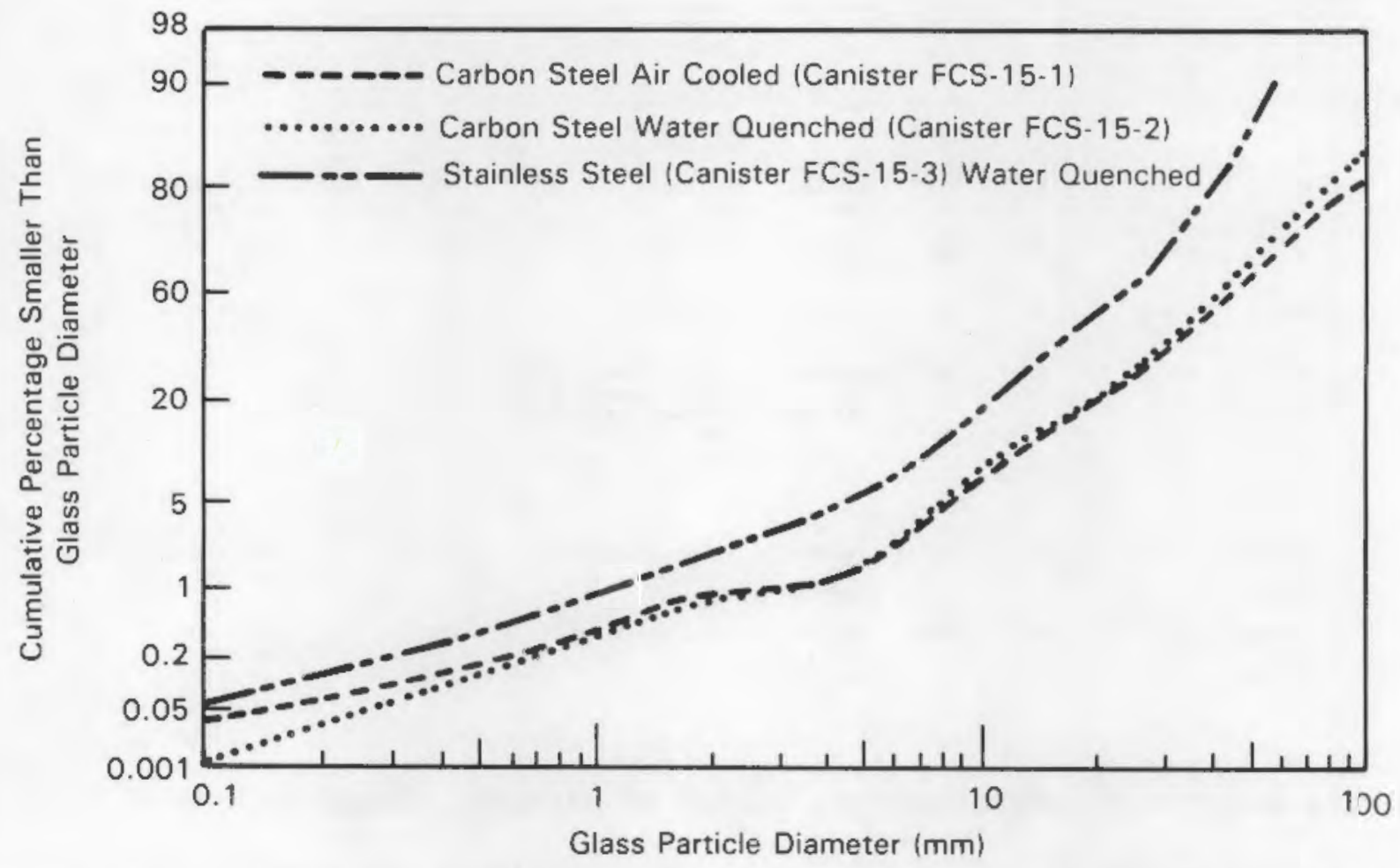

FIGURE 2.4. Particle Size Distribution (from Farnsworth, Chan and Slate 1984) 


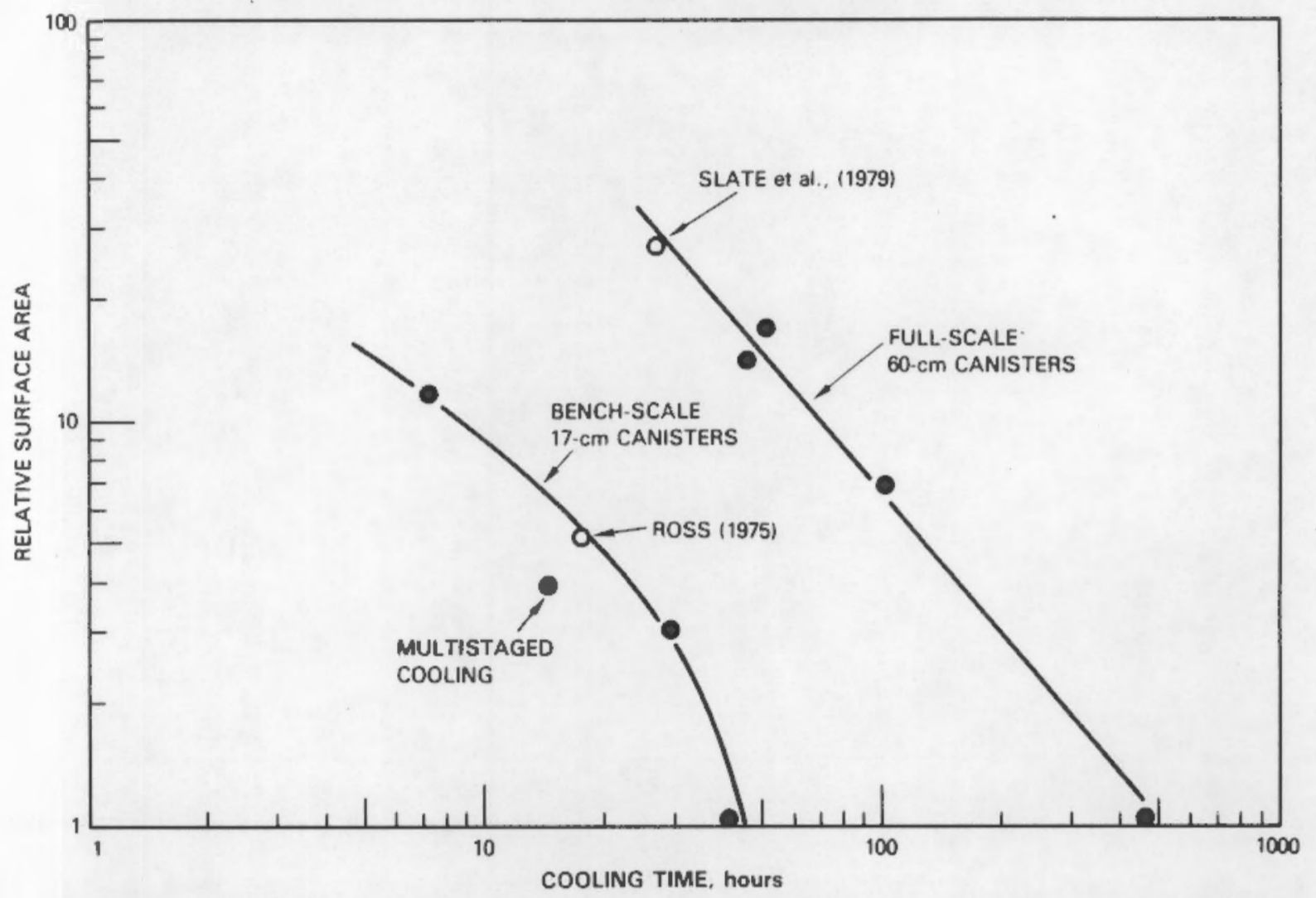

FIGURE 2.5. Effect of Cooling Time on Relative Surface Area of Thermal Cracks in Canisters $17 \mathrm{~cm}$ and $60 \mathrm{~cm}$ in Diameter (Peters and Slate 1981) 



\subsection{RESULTS OF THE PNL STUDY}

The Pilot Scale Ceramic Melter experiment 20 (PSCM-20) was undertaken for several purposes. These include the processability of a high-cesium glass composition, the deformation of the stainless steel canisters, and the cracking of the glass poured into the canisters. This section discusses the examination of two of the canisters filled during PSCM-20.

The eight canisters filled during this experiment were stainless steel with a $0.78-\mathrm{cm}$ wall and bottom thickness. Figure 3.1 is a schematic of the canister used during PSCM-20. All the canisters were internally lined with 0.31-cm Fiberfrax insulating paper. These canisters were then filled during the PSCM-20 experiment, under different filling schedules. The canisters that are discussed in detail are referred to as canister \#2 and canister \#7. (a) The top quarters of canister \#2 are referred to as $2 / 1$ and $2 / 2$ with the bottom quarters referred to as $2 / 3$ and $2 / 4$; the different quarters for canister \#7 were numbered similarly. All the canisters filled during PSCM-20 are described in detail in "PSCM-20 Canister Summary" (PNL, in preparation).

Canister 2 was filled using three batch pours. It was instrumented with 22 internal thermocouples and 8 external thermocouples to determine the thermal history of the glass during pouring and subsequent cooling. The thermal history of the glass is one of the major factors in determining the cracking. Canister \#7 was filled using six batch pours. It was instrumented with 23 internal thermocouples and 7 external thermocouples. The thermocouple locations were selected to determine temperature profiles at the following points of interest:

- near the bottom of the canister where significant temperature gradients are expected

- near the pour interfaces where cooling and reheating occur, and

- at the vertical midpoint of the pours.

(a) Canisters 2 and 7 are referred to as canisters FF-1 and FF-2, respectively, on Tables 2.1 and 4.1 . 


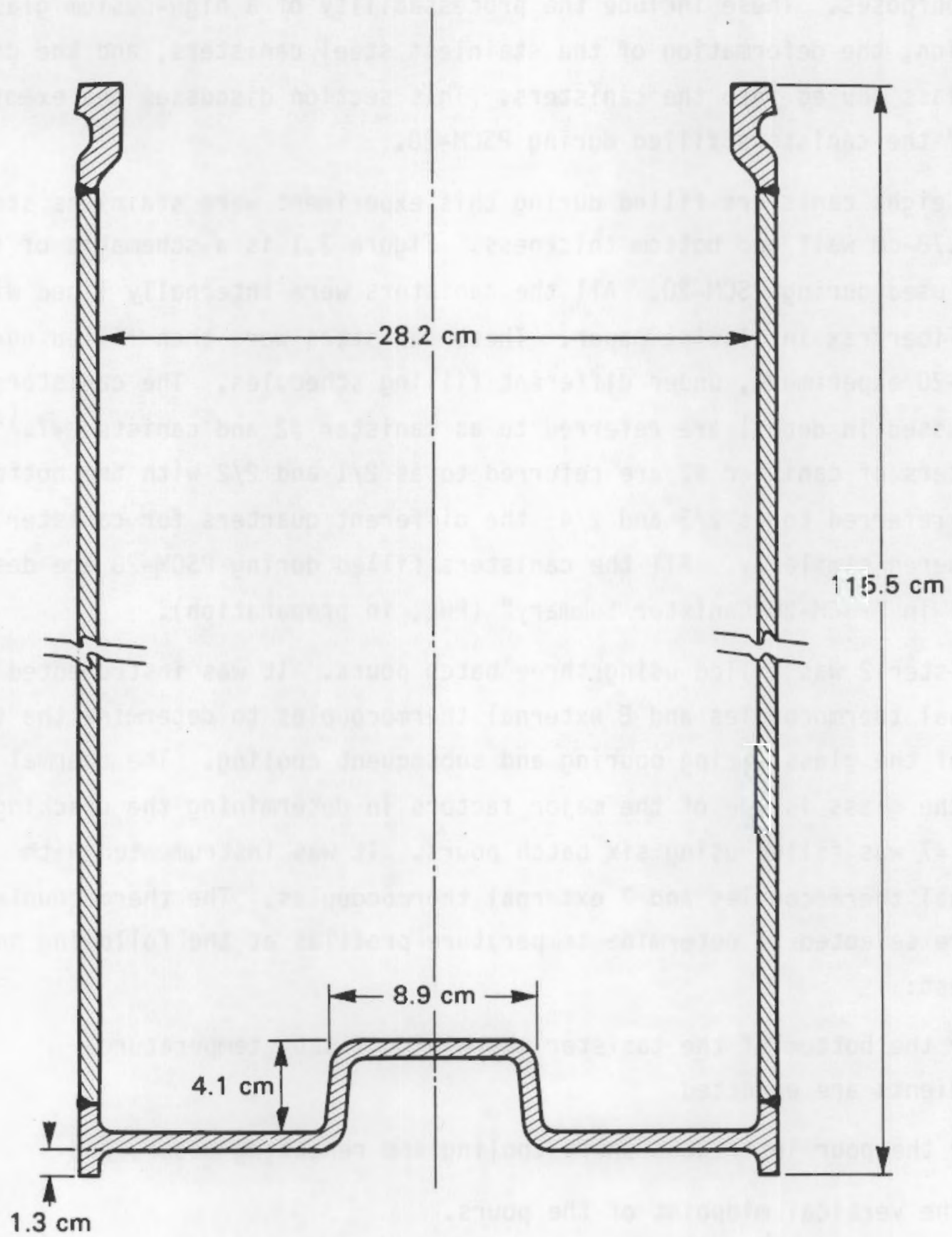

FIGURE 3.1. Cross Section of $30.5-\mathrm{cm}$ Diameter Canisters 
All the canisters poured during the PSCM-20 experiment were cut in half axially, and each half was then cut longitudinally. The stainless steel of the canister was first cut with an abrasive wheel. The bulk glass was then cut with a diamond band saw. Photographs of the canister cutting and of all eight canisters after cutting can be found in Appendix B.

\section{ESTIMATES BY FIDIJCIARY LINE METHOD}

Estimates of the surface areas of these canisters were made using several techniques. The first estimate was determined by observing the cracking on the cut surface of the canister, a technique used by Martin (1985). The cracks intersecting the surface created by the longitudinal cut were used to calculate the fracture area. The surface area of the circumferential cracks, (i.e., the crack area perpendicular to the radial axis) was estimated by assuming that each circumferential crack intersecting the sawed surface extended halfway around the canister. Figure 3.2 shows the assumed crack behavior for the circumferential cracking. The cracks on the cut surface were counted by placing fiduciary (reference) lines across the radius of the canister. The number of cracks intersecting the line at each $2.5-\mathrm{cm}$ interval of the fiduciary line was recorded. These radially oriented fiduciary lines were located every $5 \mathrm{~cm}$ along the longitudinal axis of the canister. The intersection of a crack with a radial fiduciary line was assumed to represent a $5-\mathrm{cm}$ high cylindrical surface extending halfway around the canister at the radius of the measurement.

The axially oriented crack area (i.e., the crack area perpendicular to the axis) was estimated by counting the number of crack intersections per unit length along axially oriented fiduciary lines $2.5 \mathrm{~cm}$ apart. Each crack that intersected the line was assumed to represent a $2.5-\mathrm{cm}$ wide axially oriented crack extending halfway around the canister. It appears that few cracks continue completely around the canister. Therefore, this estimating procedure should overestimate the actual surface area.

The volume associated with the crack surface areas determined with the fiduciary lines are as follows: 

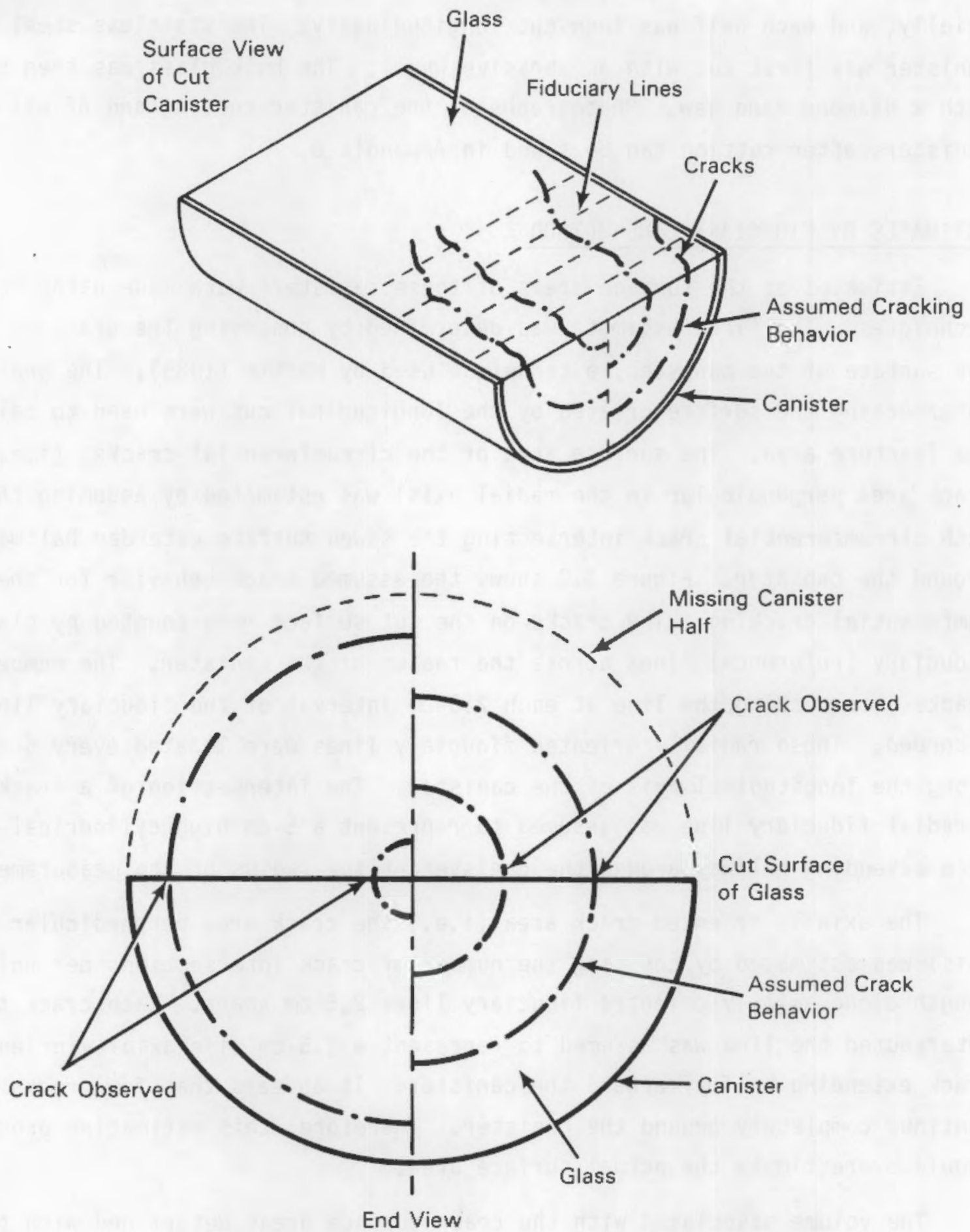

FIGURE 3.2. Circumferential Cracking Assumptions 
- At each radius where measurements were taken, the sum of the crack areas was assumed to fall within the volume of a hollow cylinder with the given mean radius and wall thickness equal to the distance between the fiduciary lines.

- At each height, the sum of the crack areas was assumed to fall within a disk with a radius equal to the canister radius and a thickness equal to the distance between the fiduciary lines.

Table 3.1 summarizes the crack surface areas estimated using fiduciary lines.

Figure 3.3 shows the variation in the axial fracture surface area to volume ratio along the length of the canister. Canisters \#2 and \#7 show similar variation with canister \#7 showing a lower average than canister \#2. There is no evidence that the axial cracking is affected by the height within the canister. Also, there was no indication of increased cracking at the pour interfaces from the batch pouring of the canister. .

Figure 3.4 shows the variation in the circumferential fracture surface area to volume ratio along the length of the canister. The most outstanding feature in this figure is the peak seen from approximately 63 to $76 \mathrm{~cm}(25$ to $30 \mathrm{in.)}$ from the bottom of the canister. This corresponds to the spherical burst in the top half of canister \#2 seen in Figures 3.5 and 3.6 . This spherical burst may account for 45 to $55 \%$ of the circumferential crack surface area estimated for the top half of canister \#2. Without the spherical burst, the estimated circumferential surface area would be decreased by at least $7,742 \mathrm{~cm}^{2}$ $\left(1200\right.$ in. $\left.{ }^{2}\right)$. TABLE 3.1. $\begin{aligned} & \text { Surface Area Estimates from Fiduciary Line Measurements } \\ & \text { (square inches) }\end{aligned}$

\begin{tabular}{|c|c|c|c|}
\hline Canister & Circumferential & Axial & Total \\
\hline $\begin{array}{l}2(\text { Top, 2/2) } \\
2(\text { Bottom, 2/4) }\end{array}$ & $\begin{array}{l}3405 \\
1970 \\
\end{array}$ & $\begin{array}{l}1560 \\
1929 \\
\end{array}$ & $\begin{array}{l}4965 \\
3899 \\
\end{array}$ \\
\hline 2 (Total) & 5375 & 3489 & 8864 \\
\hline $\begin{array}{l}7 \text { (Top, 7/1) } \\
7 \text { (Bottom, 7/3) }\end{array}$ & $\begin{array}{r}1117 \\
821 \\
\end{array}$ & $\begin{array}{l}986 \\
807 \\
\end{array}$ & $\begin{array}{l}2104 \\
1627 \\
\end{array}$ \\
\hline 7 (Total) & 1938 & 1793 & 3731 \\
\hline
\end{tabular}




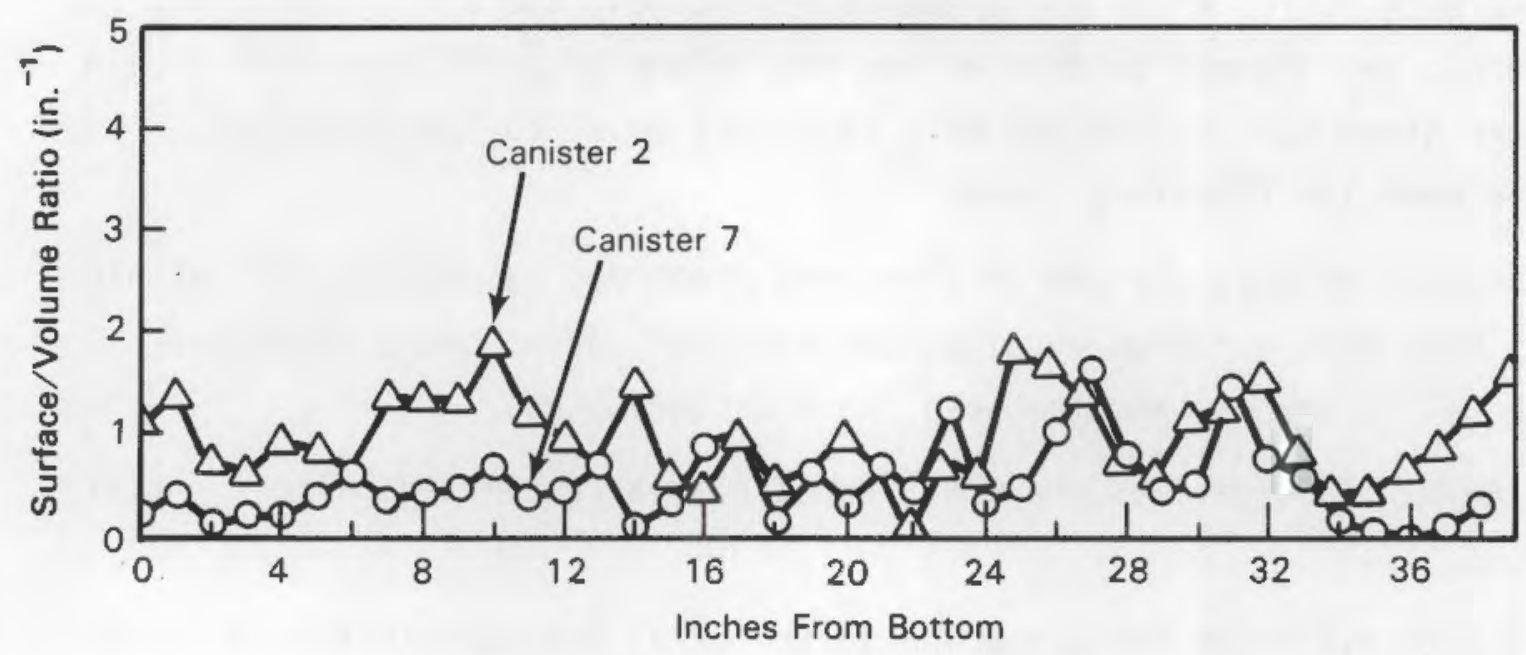

FIGURE 3.3. Axial Cracking

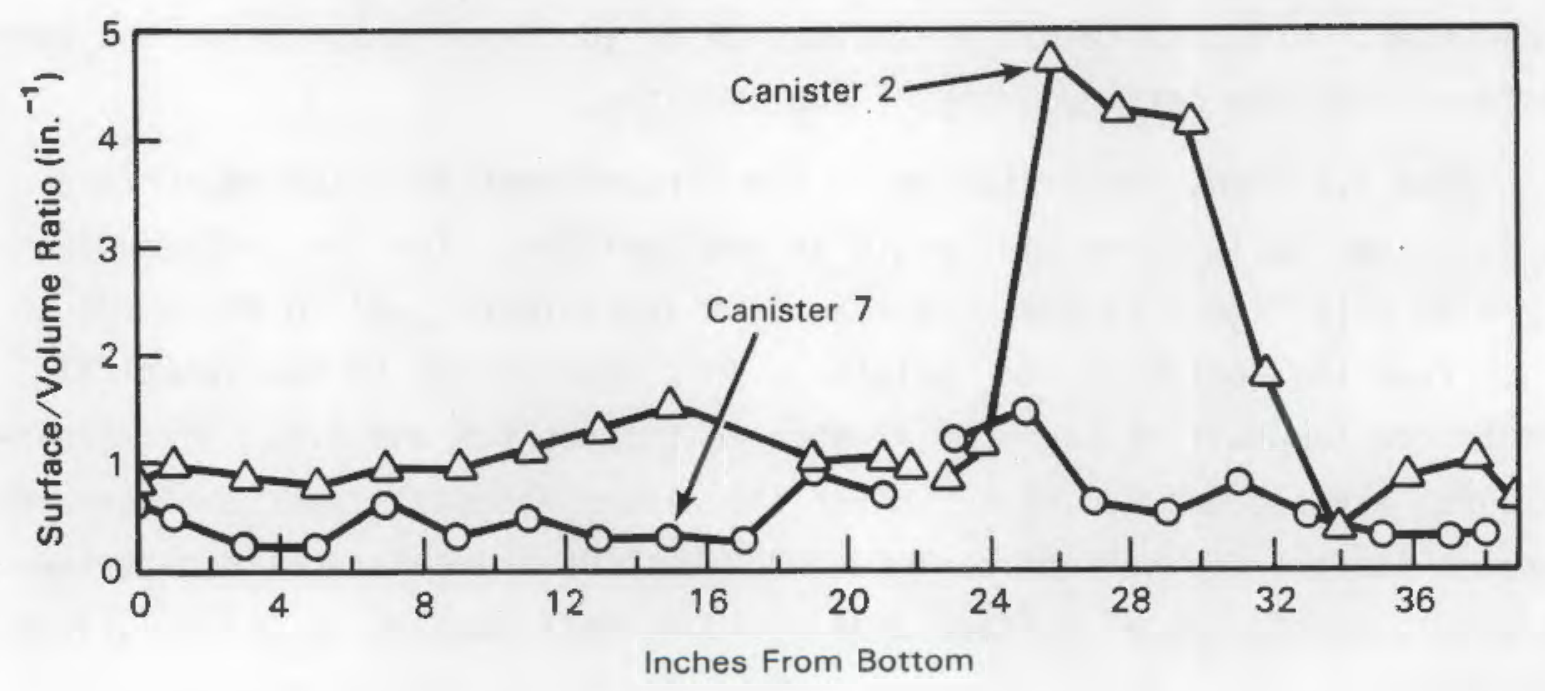

FIGURE 3.4. Circumferential Cracking

Again, the average surface/volume ratio was slightly lower for canister \#7, which was insulated with $7.5 \mathrm{~cm}$ of external insulation, than for canister \#2. As seen with the axial cracking, there is no evidence of cracking dependence on height within the canister or pour interfaces in the glass.

Figure 3.7 shows the cumulative total axial crack surface area as a function of distance from the canister centerline. There is an increase in the surface area as the outer surface of the canister is approached. This is 


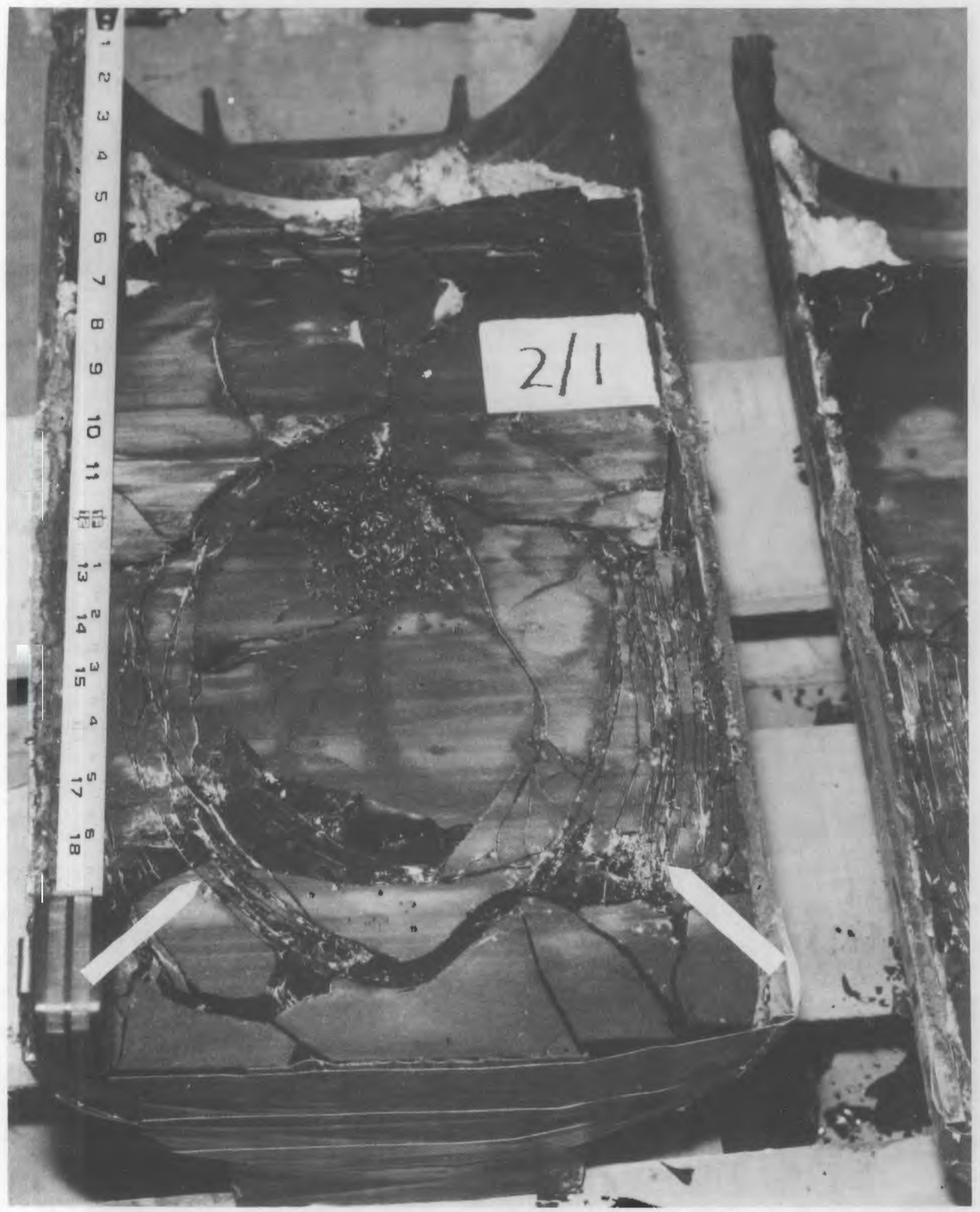

FIGURE 3.5. Canister \#2 (top quarter 2/1) Spherical Burst, Indicated by Arrows 


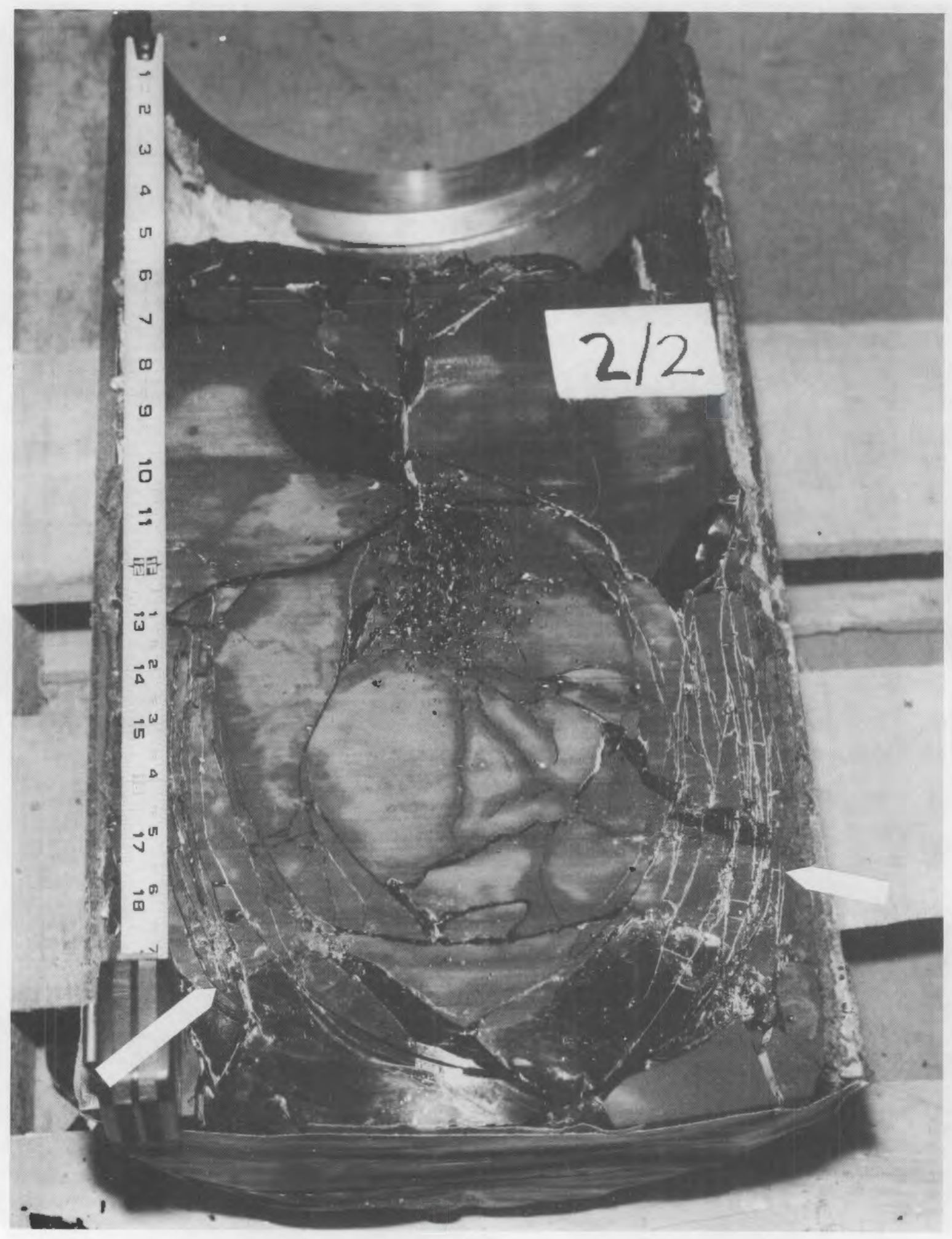

FIGURE 3.6. Canister \#2 (top quarter 2/2) Spherical Burst, Indicated by Arrows 


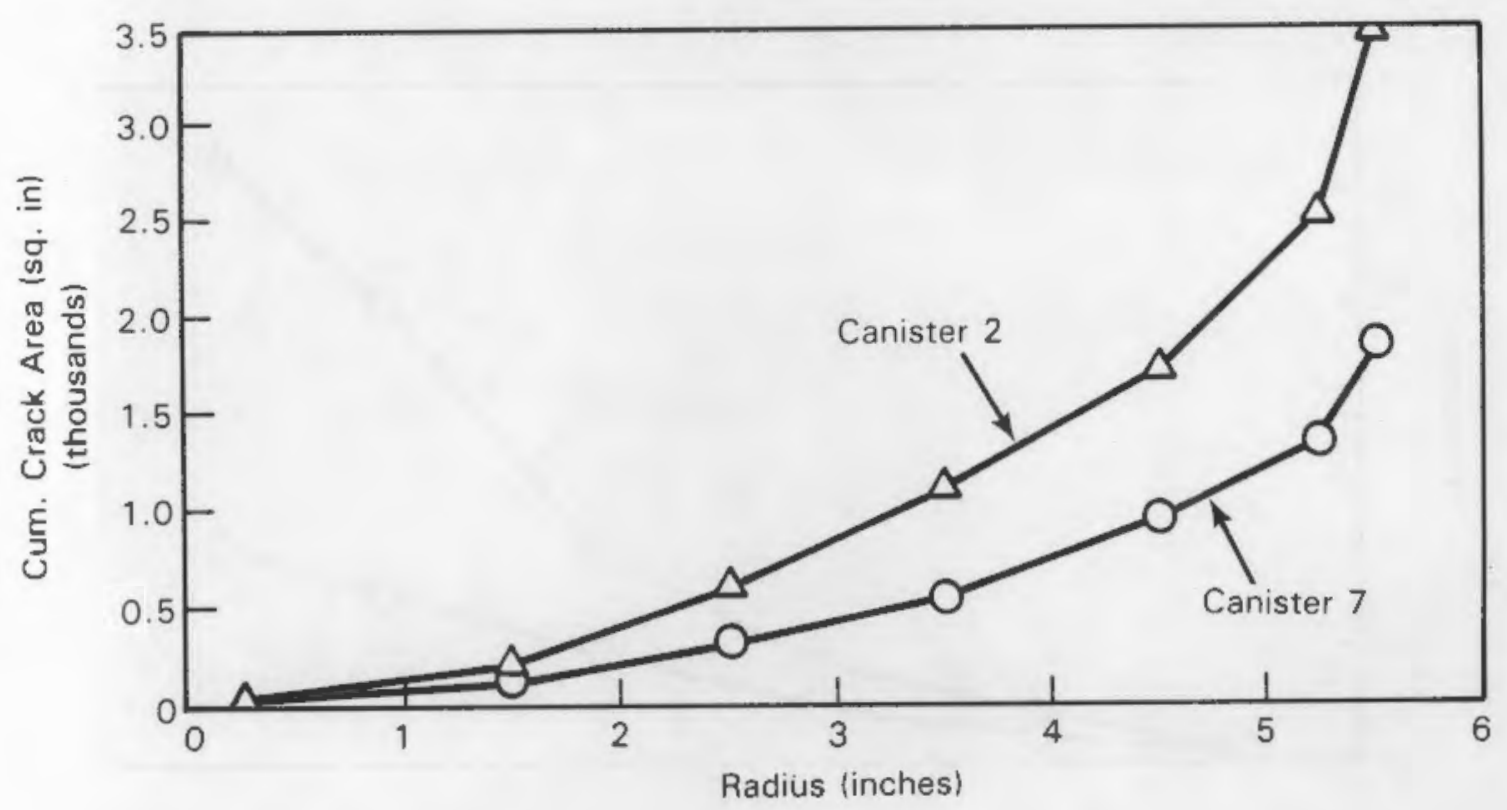

FIGURE 3.7. Cumulative Axial Crack Area as a Function of Canister Radius

expected for several reasons, including the larger temperature gradients experienced at the canister surface. Both curves showed similar behavior, with a gradual slope near the centerline of the canister and a much steeper slope toward the surface of the canister. The total surface area for canister \#7 was significantly smaller.

Figure 3.8 shows the cumulative total circumferential crack surface area as a function of distance from the canister centerline. The very steep slope of the curve for canister \#2, between 8.8 and $11.3 \mathrm{~cm}$, is due to the lamellar cracking observed on the outer edge of the spherical burst (see Figures 3.5 and 3.6). The slope of the graph for canister $\# 7$ did not change with radius, which may indicate that there is no increased cracking in canister \#7 as the canister surface is approached. The additional external insulation decreased the cracking along the surface of the canister.

\section{ESTIMATES BY PARTICLE EXAMINATION}

The second method used to estimate the surface area of the cracked glass was to examine the glass particles within the canister. Two quarters from each canisters were dismantled by hand to observe the complex cracking within the 


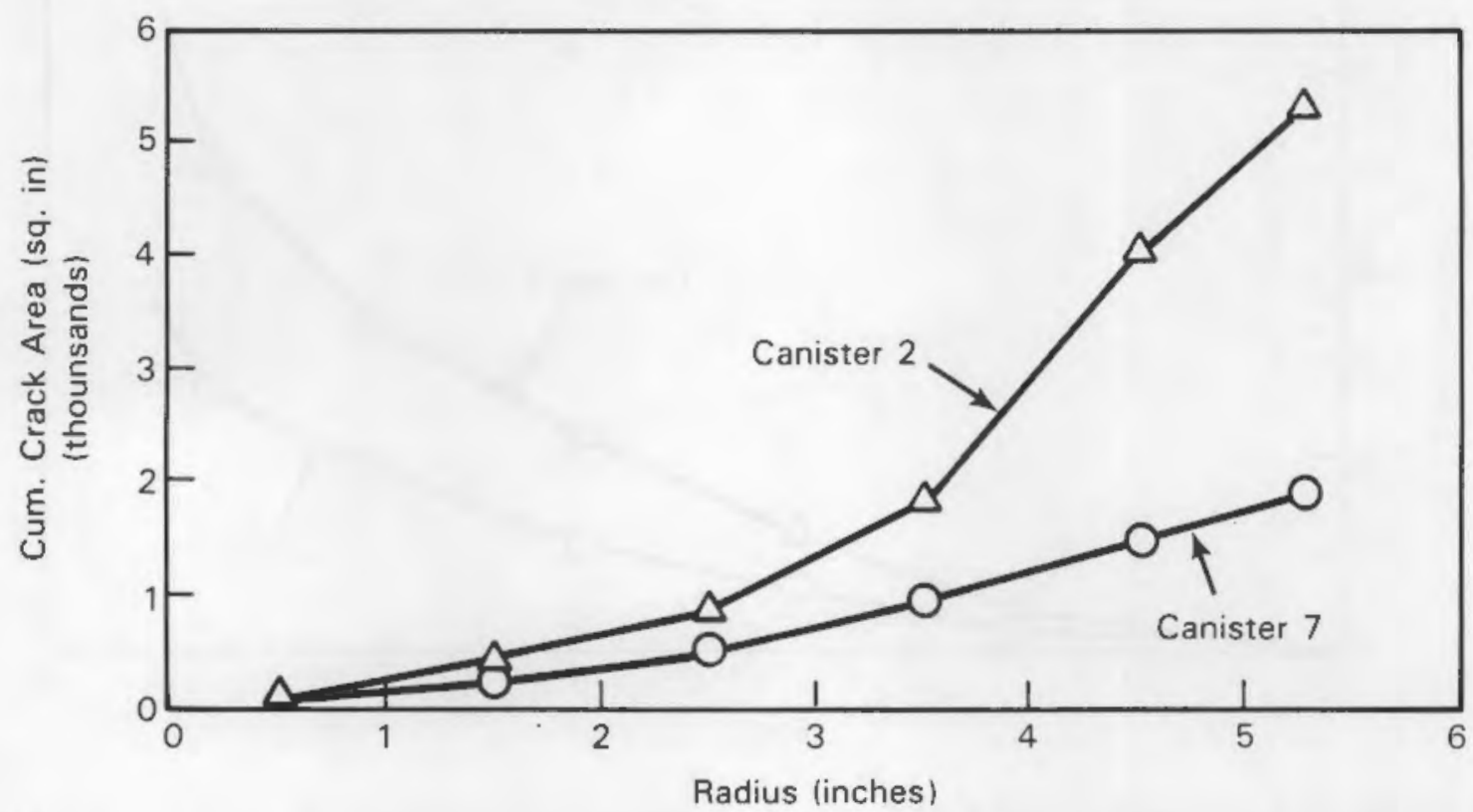

FIGURE 3.8. Cumulative Circumferential Crack Area as a Function of Distance from Canister Centerline

canister and to get a general weight/size distribution of the glass particles removed from the canister. The detailed description of the glass particles pulled from the canisters can be found on Tables A.1 through A.4 in Appendix A. The glass particles were weighed, and the surface area was estimated as if each particle was in the shape of a sphere. The glass pieces were then examined and a factor was applied to more realistically estimate the surface area. Rather than spherical, the pieces were varied in shape, including pyramid shaped, knife-like, and rectangular. Examples of some shapes of the glass pieces can be seen in Figures 3.9 and 3.10. Table 3.2 summarizes the estimates made from the glass particle size distribution.

Several important observations were made during the dismantling of the canisters:

- The thermocouples penetrating the glass did not cause localized increased cracking. In many cases, the thermocouple could be removed from the glass without breaking, indicating that there was little bonding between the glass and the thermocouple material. 

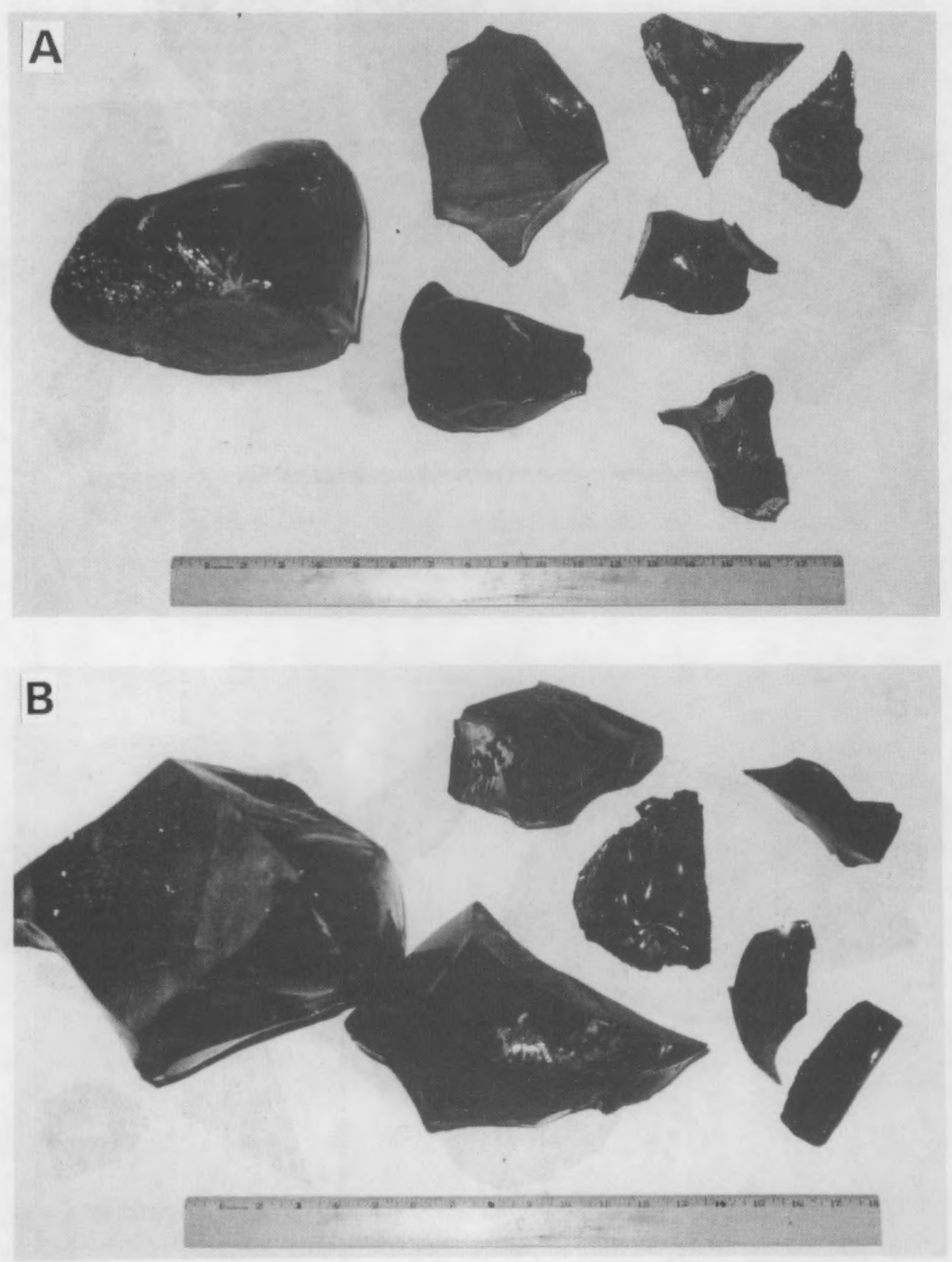

FIGURE 3.9. Glass Pieces from the Top (a) and Bottom (b) of Canister \#2 

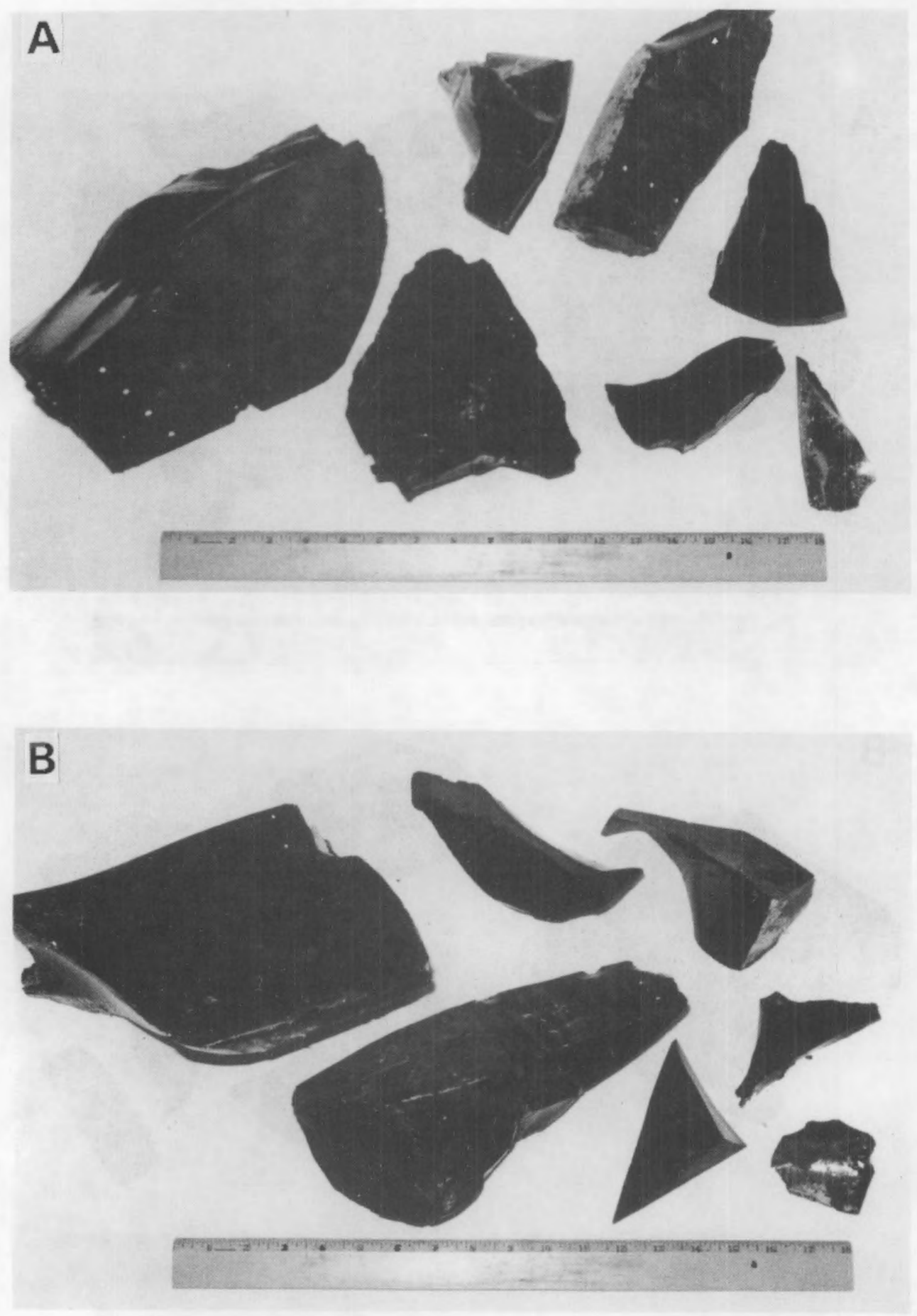

FIGURE 3.10. Glass Pieces from the Top (a) and Bottom (b) of Canister \#7 
TABLE 3.2. Surface Area Estimates from Glass Particle Sizes (square inches)

\begin{tabular}{|c|c|c|}
\hline $\begin{array}{l}\text { Canister } \\
\text { Section }\end{array}$ & $\begin{array}{l}\text { Spherical } \\
\text { Surface }\end{array}$ & $\begin{array}{c}\text { Adjusted } \\
\text { Area } \\
\end{array}$ \\
\hline $\begin{array}{l}2(\operatorname{Top} 2 / 1) \\
2(\text { Bottom 2/4) }\end{array}$ & $\begin{array}{l}1672 \\
1953\end{array}$ & $\begin{array}{l}8608 \\
4251\end{array}$ \\
\hline 2 (Total) & 3625 & 12,859 \\
\hline $\begin{array}{l}7(\text { Top } 7 / 1) \\
7(\text { Bot tom } 7 / 3)\end{array}$ & $\begin{array}{l}1183 \\
1297\end{array}$ & $\begin{array}{l}2435 \\
2088\end{array}$ \\
\hline 7 (Total) & 2480 & 4523 \\
\hline
\end{tabular}

- There was no interaction between the glass and the Fiberfrax liner. The Fiberfrax was easily swept from the surface of the glass. The glass that was in contact with the insulation had its surface molded to the shape of the surface of the Fiberfrax.

- There was no evidence of glass fines within the canister.

\section{COMPARISON OF METHODS FOR ESTIMATING SURFACE AREAS}

Table 3.3 summarizes the results of the different methods for determining the surface areas of the cracks in the glass. With both methods, the cracking in canister \#7 was approximately half that found in canister \#2.

TABLE 3.3. Summary of the Surface Area Techniques

Description
$\begin{aligned} & \text { Relative Area (b) (assuming } \\ & \text { spherical shapes) }\end{aligned}$
$\begin{aligned} & \text { Relative Area (using } \\ & \text { adjusted surface area) }\end{aligned}$
$\begin{aligned} & \text { Relative Area using } \\ & \text { fiduciary lines }\end{aligned}$
$\begin{aligned} & \text { (a) } \\ & \text { Quarter } 2 / 1 \text { was dismantled to get the particle } \\ & \text { Surface areas; quarter } 2 / 2 \text { was measured using the } \\ & \text { fiduciary lines. }\end{aligned}$
(b) Relative area = surface area of the glass monolith
plus the surface area of the cracks divided by the
surface area of the glass monolith.





\subsection{METHOO FOR ESTIMATING EXTENT OF CRACKING}

This section describes the need for a method for estimating the extent of cracking in waste glass canisters, briefly reviews the limitations of current models, and presents a proposed method for estimating cracking. The agreement between the predictions of this proposed method and the experimental data is examined along with a description of how to apply this method to conditions of nonsteady cooling.

Because destructive examination of radioactive canisters to determine the extent of cracking is extremely expensive, if not impossible, a method for estimating cracking is important. This estimation method could be used to accomplish several things. First, this method could be used, in both new and existing facilities, to determine process conditions that would result in canisters with acceptable ranges of cracking. Second, given the process proposed, computations of radionuclide release rates could be adjusted according to the computed crack areas, if the dependence is significant.

Peters and Slate (1981) plotted crack areas in terms of the relative area as a function of cooling time (See Figure 2.5). Separate curves, of different shapes, were required for the two diameters studied. A preferable method for predicting crack surface area would eliminate the dependency on diameter and on as many process variables as possible.

Martin (1985) developed a computer model that made use of a computation of the thermal history to compute the accompanying stress history within a canister. He stated that the model was simplistic in that crack initiation and propagation were not taken into account. Cracking was assumed to be by concentric failure giving circumferential cracking only. The correlation had the advantage of requiring only a knowledge of the Biot number (a measure of external versus internal heat transfer resistance, defined as the overall outside heat transfer coefficient divided by the product of the thermal conductivity of the glass and the radius of the canister). Although significant scatter was observed, this correlation had the advantage of accounting for diameter. 
Several approaches to simple correlations were attempted in this study. The most successful one was found to be a simple plot of the relative surface area against the radial temperature difference of the glass determined when the centerline temperature was $500^{\circ} \mathrm{C}$. Figure 4.1 presents a plot of the adjusted relative surface area versus radial temperature difference for all canisters that were cooled under constant cooling conditions. Table 4.1 presents much of the same information as Table 2.1, but also includes information pertinent to the discussion that follows. Before examining the accuracy of the correlation, the methods used to obtain the adjusted surface areas and the radial temperature differences are discussed.

Relative Surface Area

The "relative surface area" is defined as the ratio of the total surface area of the glass to the surface area of the glass within the canister if it were crack free. Thus the glass in a canister with a relative surface area of 10 has a total surface area 10 times that of the glass in a crack-free canister of the same size. This provides a convenient measure of the maximum effect of cracking upon the surface that could be exposed to water in a repository (some of the cracks that are completely internal to the canister would not be exposed to groundwater at all). An alternative method of plotting surface area would be in terms of surface area per unit volume. This is a simple computation to make; it too could be correlated by plotting surface area per unit volume against radial temperature difference, analogous to Figure 4.1 .

The term "adjusted surface area" is used to differentiate between the surface area of the canisters computed by the sources listed in Table 4.1 and the corrections applied here. The surface areas presented in Table 4.1 were determined by a number of methods. These included:

- adding the length of lines on a radial section and multiplying by the length of the glass; this assumes that the lines run straight along the length of the canister (Peters and Slate 1981) 


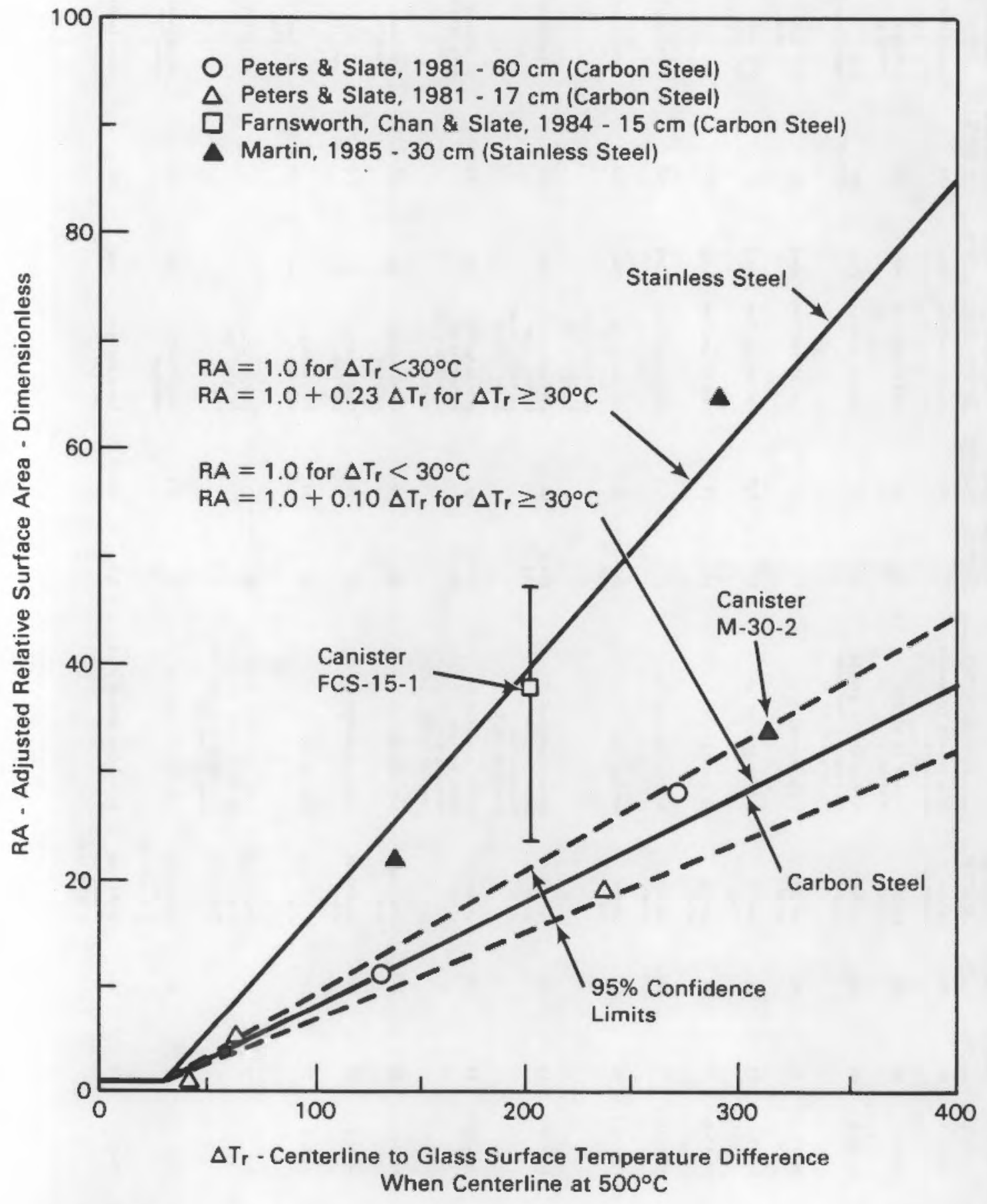

FIGURE 4.1. Correlation Between Relative Surface Area and Radial Temperature Difference at $500^{\circ} \mathrm{C}$ Centerline Temperature 
TABLE 4.1. Summing of All Available Data

\begin{tabular}{|c|c|c|c|c|c|c|c|c|c|c|c|c|}
\hline Study & \multicolumn{2}{|c|}{$\frac{\text { Canister Desl gnation }}{\text { Original Phis }}$} & $\begin{array}{c}\text { Dlamoter } \\
\mathrm{Cm}\end{array}$ & $\begin{array}{c}\text { Length } \\
\mathrm{Cm}\end{array}$ & $\begin{array}{l}\text { Canlster } \\
\text { Materlal }\end{array}$ & Cooling History & $\begin{array}{r}\begin{array}{r}\text { Rolat1 } \\
\text { Surface } \\
\text { Source }\end{array} \\
\end{array}$ & $\begin{array}{l}\text { Ive } \\
\text { Araa } \\
\text { Adjusted }\end{array}$ & $\begin{array}{c}\text { Mothod } \\
\text { Used For } \\
\text { Rolative } \\
\text { Surtace Area } \\
\end{array}$ & $\begin{array}{c}\text { Particlo } \\
\text { Size } \\
\text { Oata } \\
\end{array}$ & $\begin{array}{l}\text { Radial } \\
\text { Temporature } \\
\text { oiff terance } \\
\text { of } 500^{\circ} \mathrm{C} \\
\end{array}$ & $\begin{array}{l}\text { Mothod Used } \\
\text { To Doternin } \\
\text { Radlus } \\
\text { Temperature } \\
\text { Olfterence }\end{array}$ \\
\hline \multirow[t]{7}{*}{$\begin{array}{l}\text { Peters and } \\
\text { Siato } 1981\end{array}$} & 144 & PS-60-1 & $\infty$ & 290 & $\begin{array}{l}\text { carbon } \\
\text { stoel }\end{array}$ & $\begin{array}{l}\text { slow cooled In double } \\
\text { enclosure }\end{array}$ & 7 & 11 & radial section & none & 130 & exper Imental - 1 \\
\hline & 151 & PS-60-2 & 60 & 290 & $\begin{array}{l}\text { corbon } \\
\text { steel }\end{array}$ & $\begin{array}{l}\text { cooled In single } \\
\text { enclosure }\end{array}$ & 18 & 28 & radial section & none & 270 & $\begin{array}{l}2 \text { D heat } \\
\text { transter }\end{array}$ \\
\hline & 200 & PS-60-3 & 60 & 290 & $\begin{array}{l}\text { carbon } \\
\text { steel }\end{array}$ & $\begin{array}{l}\text { forced oir In single } \\
\text { enclosure ofter somo } \\
\text { cooll lng (at is H) }\end{array}$ & 17 & 27 & radial section & none & $\begin{array}{l}280 \\
(300-375)\end{array}$ & $\begin{array}{l}20 \\
\text { exporimental }\end{array}$ \\
\hline & 1 & PS-17-1 & 17 & 80 & $\begin{array}{l}\text { carbon } \\
\text { steet }\end{array}$ & $5 \mathrm{~cm}$ insulation & 1 & 1 & radial sectlon & none & 43 & $\begin{array}{l}2 \text { D neat } \\
\text { transter }\end{array}$ \\
\hline & 2 & PS-17-2 & 17 & 80 & $\begin{array}{l}\text { carbon } \\
\text { steel }\end{array}$ & $2.5 \mathrm{~cm}$ Insulation & 3 & 4.7 & radial section & none & 63 & $\begin{array}{l}20 \text { neat } \\
\text { tronster }\end{array}$ \\
\hline & 3 & PS-17-3 & 17 & 80 & $\begin{array}{l}\text { carbon } \\
\text { steol }\end{array}$ & no Insulatlon & 12 & 19 & radlal sectlon & none & 235 & $\begin{array}{l}20 \text { neat } \\
\text { tronsfer }\end{array}$ \\
\hline & 4 & PS-17-4 & 17 & 80 & $\begin{array}{l}\text { corbon } \\
\text { steol }\end{array}$ & multistage cooling & 4 & 6.3 & radial section & none & $\approx 10$ & experimental \\
\hline \multirow[t]{2}{*}{$\begin{array}{l}\text { Fornsworth, } \\
\text { Chan and } \\
\text { Slate } 1984\end{array}$} & 1 & FCS-15-1 & 15 & 100 & $\begin{array}{l}\text { carbon } \\
\text { steel }\end{array}$ & amblent alr & $\begin{array}{l}25-47 \\
A v a 38\end{array}$ & NA & $\begin{array}{l}\text { estimated by } \\
\text { author from } \\
\text { particle size } \\
\text { distribution }\end{array}$ & Yos & 200 & experimental \\
\hline & 3 & FCS-15-2 & 15 & 100 & $\begin{array}{l}\text { carbon } \\
\text { steal }\end{array}$ & $\begin{array}{l}\text { water quenched } \\
\text { when surf ace } \\
\text { temperature: } \\
\text { reached } 350^{\circ} \mathrm{C}\end{array}$ & $\begin{array}{l}22-50 \\
\text { Avg } 37\end{array}$ & $\mathrm{NA}$ & $\begin{array}{l}\text { estimated by } \\
\text { author from } \\
\text { particle size } \\
\text { distribution }\end{array}$ & Yes & 450 & exper 1 mental \\
\hline $\begin{array}{l}\text { Farnsworth, } \\
\text { Cnan and } \\
\text { Slate } 1984\end{array}$ & $4 \mathrm{~A}$ & FCS-15-3 & 15 & 100 & $\begin{array}{l}\text { staln1 ess } \\
\text { stoel }\end{array}$ & $\begin{array}{l}\text { water quenched } \\
\text { when surf ace } \\
\text { temperature. } \\
\text { reached } 350^{\circ} \mathrm{C}\end{array}$ & $\begin{array}{l}42-97 \\
\text { Avo } 75\end{array}$ & NA & $\begin{array}{l}\text { estlmated by } \\
\text { author from } \\
\text { particle sIze } \\
\text { distribution }\end{array}$ & Yes & $\sim 50$ & $\begin{array}{l}\text { by analogy } \\
\text { yith FCS-15-2 }\end{array}$ \\
\hline \multirow[t]{3}{*}{$\begin{array}{l}\text { martIn } \\
1985\end{array}$} & Ac & $M-30-1$ & 30 & 213 & $\begin{array}{l}\text { stalnless } \\
\text { stoel }\end{array}$ & alr cooled & 48 & 65 & $\begin{array}{l}\text { longl tudinal } \\
\text { sectlon }\end{array}$ & no & $285 \pm 10$ & $\begin{array}{l}20 \text { heat } \\
\text { tronsfor }\end{array}$ \\
\hline & 0 & $m-30-2$ & 30 & 213 & $\begin{array}{l}\text { stainless } \\
\text { steel }\end{array}$ & water quenched & 25 & 34 & $\begin{array}{l}\text { longltudinal } \\
\text { section }\end{array}$ & no & $310 \pm 25$ & $\begin{array}{l}20 \text { neat } \\
\text { transfer }\end{array}$ \\
\hline & Ins & $M-30-3$ & 30 & 213 & $\begin{array}{l}\text { stainloss } \\
\text { steol }\end{array}$ & Insulated & 22 & 30 & $\begin{array}{l}\text { longltudinal } \\
\text { sectlon }\end{array}$ & no & $135 \pm 5$ & $\begin{array}{l}2 \text { D neat } \\
\text { transter }\end{array}$ \\
\hline Kan I & PIV/22 & $k-1$ & 30 & 80 & $\begin{array}{l}\text { stalnless } \\
\text { stael } \\
\text { tibertrax }\end{array}$ & $\begin{array}{l}3 \mathrm{hr} \text { cool down foll lowod } \\
\text { by } 24 \mathrm{hr} \text { sook ot } 550^{\circ} \mathrm{C} \\
\text { toll lowed by } 6 \text { day cool } \\
\text { down to amblent }\end{array}$ & 1.1 & & $\begin{array}{l}\text { pleces wrapped } \\
\text { in alumi num } \\
\text { foll }\end{array}$ & no & 10 & estimated \\
\hline $\begin{array}{l}\text { This } \\
\text { Study }\end{array}$ & $\begin{array}{l}\text { conlster } \\
2 \\
\text { PSCH-20 }\end{array}$ & $F F-1$ & 30 & 98 & $\begin{array}{l}\text { stoinless } \\
\text { stool } \\
\text { \& finertrax }\end{array}$ & 1/4 In. Insulation & 7 & 9.5 & $\begin{array}{l}\text { longitudinal } \\
\text { section }\end{array}$ & yes & 100 & $\begin{array}{l}\text { experimental } \\
\text { dato }\end{array}$ \\
\hline $\begin{array}{l}\text { Thls(a) } \\
\text { Study }\end{array}$ & $\begin{array}{l}\text { Canlster } \\
7 \\
\text { PSCH-20 }\end{array}$ & Ff -2 & 30 & 98 & $\begin{array}{l}\text { stolnless } \\
\text { stoel } \\
8 \text { fiberfrax }\end{array}$ & 3 In. Insulation & 3.5 & 4.8 & $\begin{array}{l}\text { longitudinal } \\
\text { sectlon }\end{array}$ & yes & 35 & $\begin{array}{l}\text { exporimental } \\
\text { data }\end{array}$ \\
\hline
\end{tabular}

(a) See Appendices Table 4.1 
- counting the number of crack crossings on fiduciary lines on the surface of a cut made lengthwise down the center of the canister (Martin 1985, see also Section 3.0)

- wrapping the glass pieces with aluminum foil and obtaining the surface area from the weight of aluminum foil required (Kahl 1985).

The last method is probably the most accurate for particles sufficiently large to handle, however it is extremely time consuming. Kahl's values were used as given. The first two methods do not measure the three components of glass surface area caused by cracking. These components are

- axial: the component of the surface area that is perpendicular to the longitudinal axis

- circumferential: the component of surface area that is perpendicular to the radii

- radial: the component of surface area that is perpendicular to the circumference.

The use of radial sections gives estimates of cracking that include circumferential components and radial components but not the axial component. Conversely, the use of longitudinal sections down the centerline of the cylinder gives estimates of cracking that include the axial and the circumferential components but not the radial components. Martin's study (see Figure 2.3) and this study (See Table 3.1) indicate that the circumferential and the axial components are roughly the same size. Applying the fiduciary line approach to the radial sections shown in Figures 2.2 and 4.2 results in values of the ratio of radial to circumferential crack area ( 1 ine lengths) of 0.79 and 0.66 , respectively. The average of these, 0.72 , was used to put the radial and longitudinal methods on the same basis. This was done as follows. Because the radial section method neglects the axial component, the adjusted area was obtained by multiplying the relative surface area obtained from the radial section by the quantity (axial area + radial area + circumferential area)/(circumferential area + radial area). Assuming that the ratio between the axial, circumferential and radial areas is $1: 1: 0.72$, we obtain a correction factor of $(1+1+$ $0.72) /(1+0.72)$ or 1.58 . Using similar logic, the correction factor for 


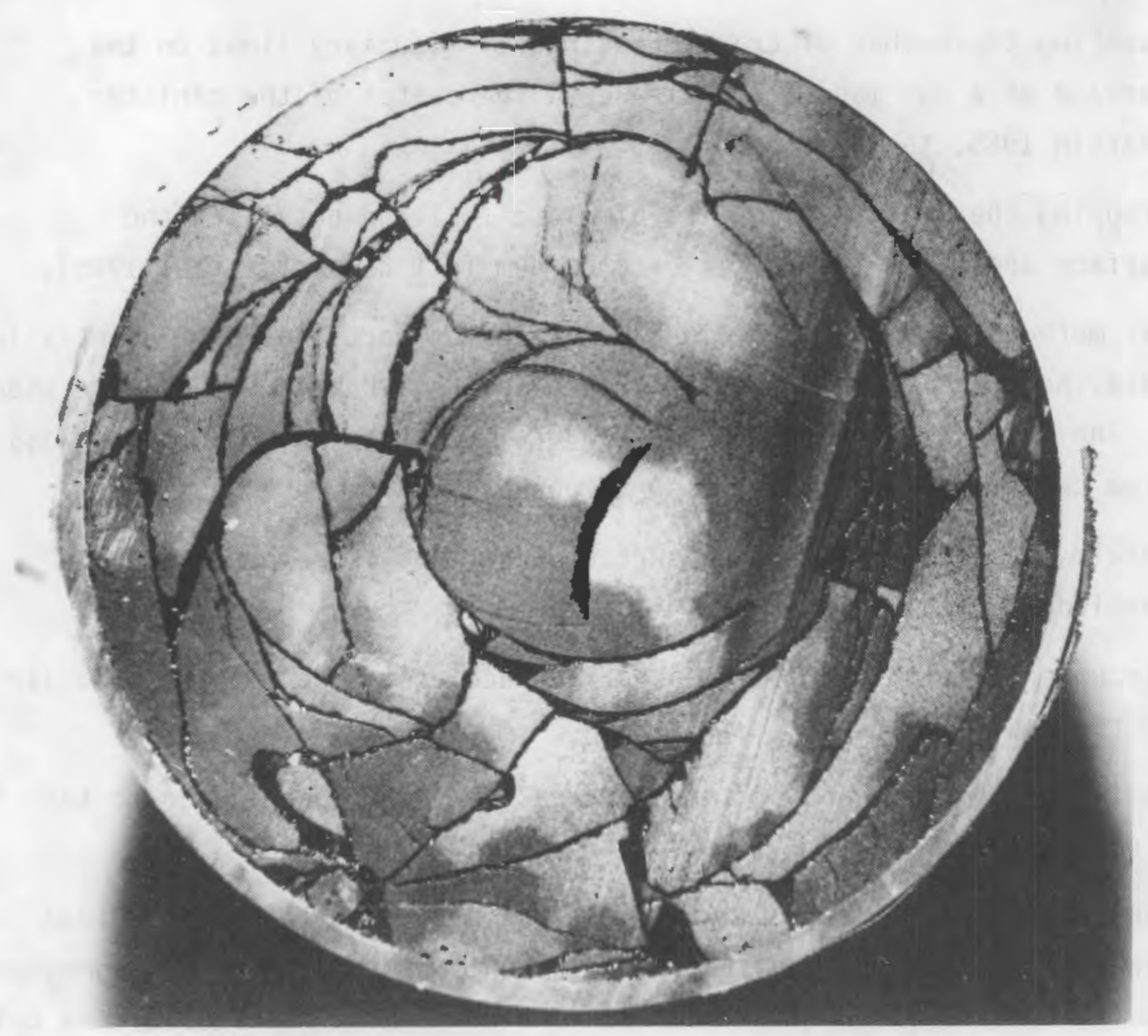

FIGURE 4.2. Radial Cross Section of Canister \#3 of Peters and Slate 1981 (canister PS-17-3 of Table 4.1)

surface areas obtained from longitudinal sectioning was computed to be $(1+1+$ $0.72) /(1+1)$ or 1.36 . These factors were used to compute the adjusted surface areas found in Table 4.1 for the studies that used radial or longitudinal sections.

Surface Area from Particle Size Distribution

Farnsworth, Chan and Slate (1984) did not measure surface area, but provided information on particle size distribution; this information is shown on Figure 2.4.

Estimates of surface area were made from this particle size information and are presented in Tables 4.1 and 4.2. As described in Section 3.0, most 
glass fragments are not spherically shaped. In order to obtain an estimate for realistically shaped particles, four PNL investigators with some experience in dismantling canisters were asked for independent estimates of correction factors to apply to the spherically based surface areas as a function of particle size. The results are presented in Table 4.2. A two-to-one range in estimated surface area was obtained; the average of these estimates was about three times the surface areas computed assuming spherical particles.

Reference Temperature

Before discussing how the radial temperature differences were computed, the definition of the radial temperature, $\Delta T_{r}$, will be given along with a brief discussion of the selection of $500^{\circ} \mathrm{C}$ for the reference temperature. By radial temperature difference, we mean the difference between the temperature of the glass at the glass centerline and at the glass surface when the centerline (reference) temperature is $500^{\circ} \mathrm{C}$. The $500^{\circ} \mathrm{C}$ reference temperature was chosen because it is slightly below the transition temperature of glasses used in

TABLE 4.2. Estimates of Relative Surface Areas from Particle Size of Farnsworth, Chan and Slate (1984)

\begin{tabular}{|c|c|c|c|}
\hline $\begin{array}{l}\text { Canister } \\
\text { Assumption }\end{array}$ & FCS $-15-1$ & FCS $-15-2$ & FCS $-15-3$ \\
\hline $\begin{array}{l}\text { Spherical } \\
\text { Particles }\end{array}$ & 12.9 & 12.2 & 23.8 \\
\hline $\begin{array}{c}\text { Nonspherical } \\
\text { (Faletti) }\end{array}$ & 47.1 & 49.5 & 97 \\
\hline $\begin{array}{l}\text { Nonspherical } \\
\text { (Slate) }\end{array}$ & 23.3 & 21.9 & 41.8 \\
\hline $\begin{array}{c}\text { Nonspherical } \\
\text { (Reimus) }\end{array}$ & 37.6 & 35.9 & 73.6 \\
\hline $\begin{array}{l}\text { Nonspherical } \\
\text { (Farnsworth) }\end{array}$ & 42.9 & 41.5 & 86.1 \\
\hline $\begin{array}{l}\text { Average of } \\
\text { nonspherical } \\
\text { estimates }\end{array}$ & 37.7 & 37.2 & 74.6 \\
\hline
\end{tabular}


waste canisters (generally $500^{\circ} \mathrm{C}$ to $600^{\circ} \mathrm{C}$ ). Thus, at $500^{\circ} \mathrm{C}$, the process of creating residual stresses would have been completed. The choice of $500^{\circ} \mathrm{C}$ for the reference centerline temperature is somewhat arbitrary. The choice of another temperature would have the effect of changing the slope of the lines on Figures 4.1 and 4.3; a higher reference temperature results in a high radial temperature difference and, therefore, a lower slope. $500^{\circ} \mathrm{C}$ seemed to be a good compromise between ensuring that the process of creating residual stresses was completed and yet being near or above the likely temperatures where changes in cooling conditions would likely be made in actual canister production. Such changes are most likely to be made after the canister has been allowed to soak at or near $500^{\circ} \mathrm{C}$ to allow for annealing. Examples of how the correlation can be used for such cases is given later in the subsection "Nonsteady Cooling."

\section{Radial Temperature Differences}

The radial temperature differences were obtained either from experimental data or by computation using the simplification of two-dimensional heat transfer. By radial temperature difference, we mean the difference between the temperature of the glass at the glass centerline and at the glass surface when the centerline temperature is $500^{\circ} \mathrm{C}$. Canister FCS-15-3 was assumed to have the same cooling rate as canister FCS-15-? because the same cooling scheme was reported to be used.

The two-dimensional heat transfer computation made use of standard solutions for two-dimensional heat transfer (Figures 4.11 and 4.12 in Principles of Heat Transfer, Kreith 1973). The experimentally determined centerline temperature as a function of time was used in conjunction with the figures from Kreith to compute the radial temperature difference when the centerline temperature was $500^{\circ} \mathrm{C}$.

\section{AGREEMENT BETWEEN CORRELATION AND DATA}

The agreement between the correlation and the model is discussed for the following cases: 


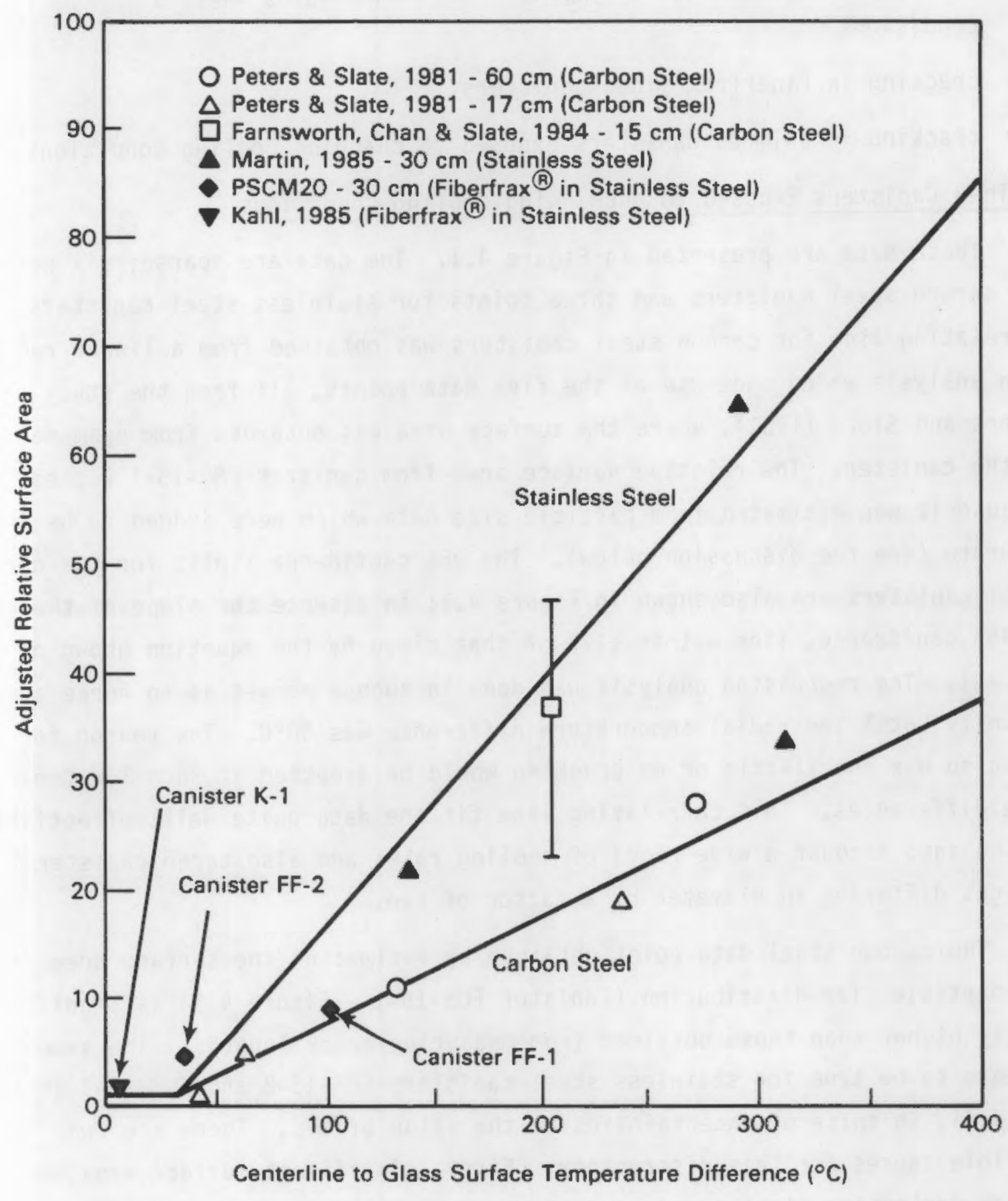

FIGURE 4.3. Comparison of Fiberfrax-Lined Canister with Correlation 
- cracking in unlined canisters exposed to unchanging cooling conditions

- cracking in Fiberfrax lined canisters

- cracking in unlined canisters exposed to changing cooling conditions. Unlined Canisters Exposed to Unchanging Cooling Conditions

These data are presented in Figure 4.1. The data are sparse; six points for carbon steel canisters and three points for stainless steel canisters. The correlating line for carbon steel canisters was obtained from a 1 inear regression analysis which made use of the five data points, all from the study of Peters and Slate (1981), where the surface area was obtained from examination of the canister. The relative surface area from canister FSC-15-1 was not used because it was estimated from particle size data which were judged to be less accurate (see the discussion below). The 95\% confidence limits for the carbon steel canisters are also shown in Figure 4.1; in essence the slope of the line at $95 \%$ confidence, lies within $\pm 17 \%$ of that given by the equation shown on Figure 4.1. The regression analysis was done in such a manner as to force a value of unity until the radial temperature difference was $30^{\circ} \mathrm{C}$. The reason for doing so was that little or no cracking would be expected at such low temperature differences. This correlating line fit the data quite well, effectively taking into account a wide range of cooling rates and also three canister designs differing in diameter by a factor of two.

The carbon steel data point obtained by estimating the surface area from the particle size distribution (Canister FCS-15-1 - Figure 4.1) is significantly higher than those obtained from measuring crack lengths. The same appears to be true for stainless steel canisters FCS-15-2 and FCS-15-3 (Figure 4.4), in spite of uncertainties in the value of $\Delta T_{r}$. There are two possible causes for this discrepancy. First, significant surface area was formed during the sieving and separating process. Second, the estimates made by the four investigators and presented in Table 4.2 were made without an opportunity to examine the glass. Not only was a two-to-one range of estimated 
surface area obtained, but it is possible that all four investigators made high estimates. Significantly, the lowest estimates came from Slate, who has the most experience.

In an attempt to get a comparison between the predictions of the two methods, both the fiduciary line-intersection and the particle size techniques were used to obtain relative area estimates for the canisters examined in Section 3.0. As Table 4.3 shows, the nonadjusted relative area obtained using fiduciary lines lies between the surface areas estimated from assuming spherical particles and that estimated by applying correction factors for nonspherical particles. However, when the relative area is corrected for the missing

TABLE 4.3. Comparison of the Surface Area Techniques

\begin{tabular}{|c|c|c|}
\hline Description & Canister $\# 2^{(a)}$ & Canister \#7 \\
\hline $\begin{array}{l}\text { Relative Area (b) } \\
\text { (assuming spherical } \\
\text { shapes) }\end{array}$ & 3.4 & 2.65 \\
\hline $\begin{array}{l}\text { Relative Area } \\
\text { (using adjusted } \\
\text { surface area from } \\
\text { particle size data and } \\
\text { particle shape estimates) }\end{array}$ & 9.4 & 4.0 \\
\hline $\begin{array}{l}\text { Relative Area } \\
\text { using fiduciary } \\
\text { lines }\end{array}$ & 6.8 & 3.5 \\
\hline $\begin{array}{l}\text { Relative Area } \\
\text { using fiduciary } \\
\text { lines and correcting } \\
\text { for missing radial } \\
\text { component }\end{array}$ & 9.3 & 4.8 \\
\hline
\end{tabular}

(a) For canister \#2, quarter $2 / 1$ was dismantled to get the particle surface areas and quarter $2 / 2$ was measured using the fiduciary lines.

(b) Relative area = surface area of the glass monolith plus the surface area of the cracks divided by the surface area of the glass monolith. 
radial component of surface area by multiplying by 1.36 (discussed earlier in this section) the two methods agree to within $20 \%$ or better. Although this agreement may be fortuitous because only one person estimated the nonspherical correction factors, it indicates that, at least for Fiberfrax-lined canisters, good agreement was obtained between the two methods. However, the authors had an opportunity to observe the shapes of the particles from FF-1 and FF-? and to then estimate appropriate nonspherical correction factors as a function of particle size. Examination of the particles from canisters FCS-15-1, FCS-15-2 and FCS-15-3 was obviously impossible because the glass had been disposed of, and examination of the small particles found in those canisters would have been much more difficult.

It is likely that the discrepancy between relative-area estimates obtained from examination of sections cut through the glass and estimates from particle size data is caused both by differences in the amount of additional cracking during dismantling and sieving and by uncertainties in the shapes of the particles. The relative importance of these two factors cannot be determined without more data.

The stainless steel data were correlated, by analogy with the the data for the carbon steel canisters, with a straight line. Only two data points were used to draw this line; the data point for canister M-30-2 (Figure 4.1) was ignored in drawing the line for stainless steel canisters. This action was justified because the canister was filled while immersed in water; the resulting glass behavior, as will be discussed below, caused cracking more analogous to that of a carbon steel canister than a stainless steel canister. clearly, more data are needed to determine whether the straight line correlation is also valid for stainless steel canisters. However, the greater slope is consistent with an the effect that has been observed by a number of investigators: that unlined stainless steel canisters exhibit more glass cracking than do carbon steel canisters. This is because of the bonding of glass to stainless steel and because stainless steel's coefficient of thermal expansion differs more from that of glass than does carbon steel's coefficient of thermal expansion. The bonding leads to creation of a great deal of fine particles at the surface; the difference in the thermal coefficient of expansion leads to crack-producing compressive and shear stresses in the glass. 
Canister M-30-2, as stated above, was filled while immersed in water. The glass was rapidly cooled; as a result, the glass did not reach the canister wall in some places, in other places only weak contact was made (Martin 1985). Thus this canister exhibited cracking similar to that of an unlined carbon steel canister because (a) the glass surface was too cold to bond to the stainless steel and (b) the poor physical contact eliminated much of the effect of the difference between glass and stainless steel's coefficient of expansion. Canister M-30-2 illustrates an important point: the need for accurate thermal information and for a knowledge of the physics of glass flow. The lack of good physical contact between the glass and the wall of canister M-30-2 introduced a significant thermal resistance between the glass and the canister wall (Martin 1985). This thermal resistance reduced the radial temperature difference (compared to that of an air-cooled canister) from $400^{\circ} \mathrm{C}$ to $300^{\circ} \mathrm{C}$. A heat transfer analysis that assumed good thermal contact (a reasonable assumption to someone not familiar with glass flow in canisters) would have overpredicted the radial temperature difference. Physical interation between canister and glass was only slight, so the cracking action of the stainless steel canister was similar to that of a carbon steel canister. This hehavior, combined (to a lesser extent) with a smaller difference in radial temperatures, reduced the cracking by a factor of two.

Fiberfrax-Lined Canisters

The data points for the three Fiberfrax-lined canisters are plotted on Figure 4.3 for comparison with the data from the unlined canisters exposed to constant cooling conditions, presented in Figure 4.1. Two of the three canisters were cooled under constant cooling conditions; these canisters (FF-1 and $\mathrm{FF}-2$ are referred to as canisters \#2 and \#7, respectively, in Section 3.0). The remaining canister $(K-1)$ was allowed to cool for 3 hours, then it was placed in a furnace held at $550^{\circ} \mathrm{C}$ for 24 hours, followed by an extremely slow ( 6 days) cooldown to room temperature. An estimate of $10^{\circ} \mathrm{C}$ was made for the radial temperature difference in canister $\mathrm{K}-1$ at $500^{\circ} \mathrm{C}$.

As plotted on Figure 4.3, the canister $k-1$, because of its extremely low $\Delta T_{r}^{\prime}$, lies near both the carbon steel and the stainless steel correlating lines. Canister FF-2 lies above both the carbon steel and the stainless steel 


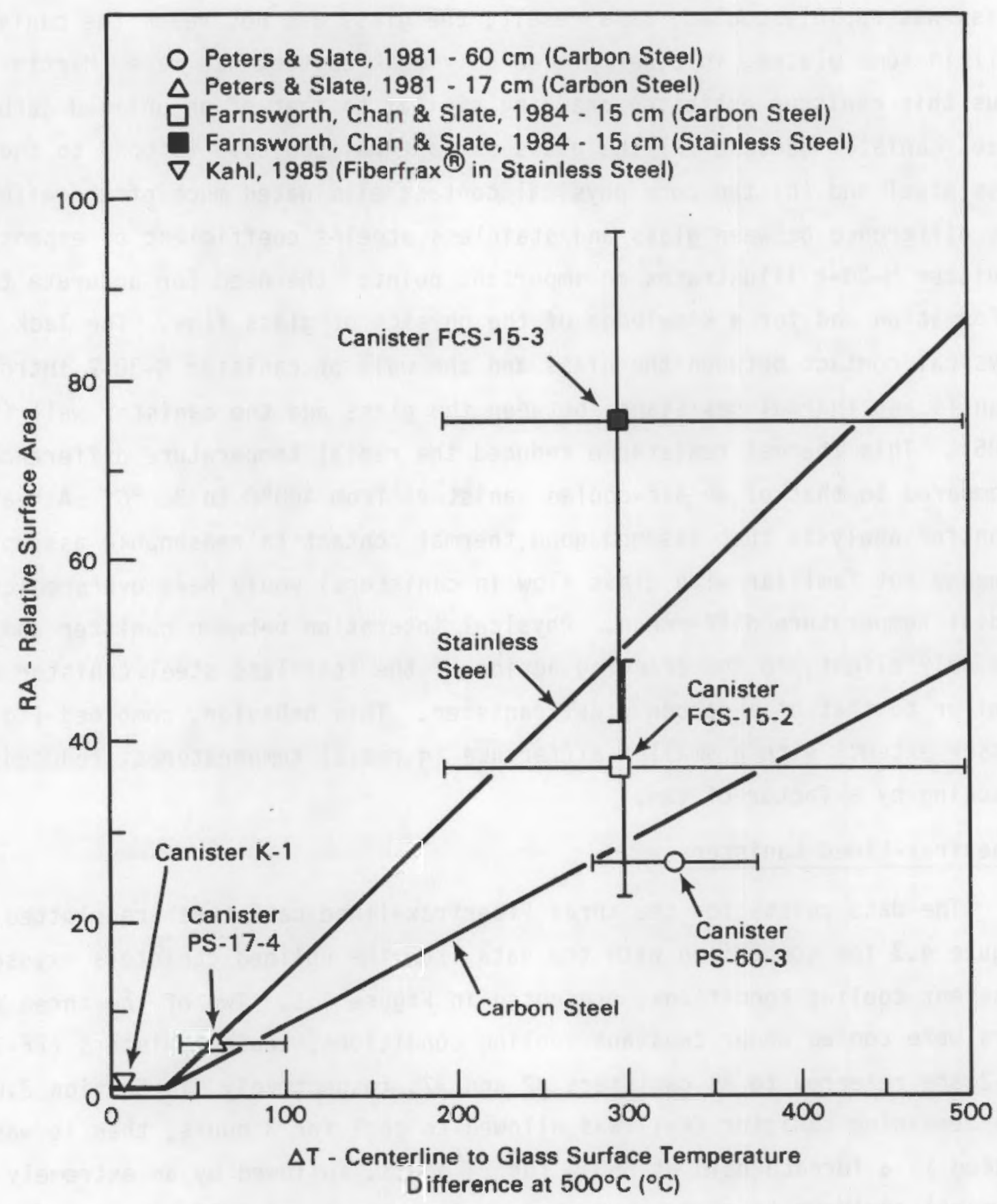

FIGURE 4.4. Results Obtained from Changing Cooling Conditions 
lines but within the scatter of the carbon steel data. Canister FF-1, the only canister with a $\Delta T_{r}$ sufficiently large that the two correlating lines differ significantly, lies on the carbon steel correlating line and nearly a factor of two in relative area below the stainless steel correlating line. Thus, for the case of canister FF-1, it appears that the use of Fiberfrax probably reduced the amount of cracking below that which would have occurred in an unlined stainless steel canister.

That the relative areas of FF-1 and FF-2 are not even smaller is surprising because, as discussed in Section 3.0, few fines or even small particles were found in PNL's Fiberfrax-lined canisters. Considerable generation of fines would be expected in an unlined carbon steel canister at the temperature differences experienced by the Fiberfrax-lined canisters. Thus it was expected, on the basis of qualitative visual observations hy personnel experienced in the cracking behavior of carbon steel and stainless steel canisters, that the data points for FF-1 and FF-? would lie below the carbon steel correlating line. It is possible that the qualitative inferences were wrong; however, several possibilities exist that would explain why the relative areas of the Fiberfrax-lined canisters were not lower. The canisters were filled by batch rather than by the continuous filling used for all other canisters. Furthermore, the Fiberfrax-lined canister areas were estimated from longitudinal sections, whereas the carbon steel correlating line was based on data obtained from examination of radial sections. When a canister having significant internal stresses is cut--and all nonannealed galss canisters have such stress--the formation of new cracks is inevitable as a result of strain relief and stress redistribution. Longitudinal sectioning may create more "new" crack areas than does radial sectioning. If this is the case, then a nonsectioned, Fiberfrax-lined canister could indeed have much less cracking than is indicated on Figure 4.3 .

Note, however, that Martin (1985) also used longitudinal sectioning. If longitudinal sectioning does indeed increase the surface area estimate, then the correlation for stainless steel comes into question because, except for the data shown on Figure 4.4, it is entirely dependent upon Martin's data. On the 
other hand, the percentage of additional cracking caused by the strain relief following sectioning would be expected to increase as the value of relative area decreased. The reason is that smaller relative areas are associated with larger pieces of glass. For a given amount of strain energy per unit volume, the effects of a saw cut are larger with larger particles because a larger fraction of the particles are cut during sectioning. Therefore, the additional cracking caused by strain relief would be expected to be smaller for Martin's canister than for the Fiberfrax-lined canisters. Clearly, additional data, where canisters with the same cooling history are sampled by both radial and longitudinal sectioning, are needed to resolve this issue. Application of Correlation to Changing Cooling Conditions

The correlation can be applied to changing cooling conditions. Canister $\mathrm{K}-1$, described above, was subjected to a change in cooling conditions to reduce the amount of cracking. Applying the correlation to canister $k-1$ was relatively straightforward because the temperature differences in the canister were allowed to fall to very low values at or near the transition temperature, and cooling continued at a very slow rate thereafter. Thus the choice of a radial temperature difference $\left(10^{\circ} \mathrm{C}\right)$ was a simple matter (Figure 4.4 ).

When the change in radial temperature difference is large, a more complex approach must be used. Methods of using this approach will depend upon the temperature history of the canister; examples are given below. Before proceeding, it will be worthwhile to give the basis for the approach taken, which was to obtain maximum, minimum, and best estimates of the radial temperature difference for use with the correlation, and thus to estimate the probable range of cracking. The canisters discussed below were all subjected to increased cooling rates following an initial slower cooling rate.

First, an estimate is made of the effective radial temperature difference to use for residual stresses. If the canister has been allowed to cool at a steady cooling condition until its centerline reaches $500^{\circ} \mathrm{C}$, the procedure is identical to that of steady cooling conditions. If the cooling rate is increased when some of the glass is above $500^{\circ} \mathrm{C}$, an estimate is made of the radial temperature difference "at $500^{\circ} \mathrm{C}$ equivalent" that would represent the 
amount of residual stress. This value is used to provide the lower bound of the estimated radial temperature for use with the cracking correlation.

The upper bound of the estimated radial temperature for use with the cracking correlation is obtained by finding the maximum radial temperature difference that occurs after the centerline of the glass has dropped to $500^{\circ} \mathrm{C}$. This temperature difference is a measure of the maximum thermal stresses that can be set up as a result of the increased rate of cooling. The limitation of $500^{\circ} \mathrm{C}$ is used because the glass, according to the quick-freeze model, is incapable of maintaining thermal stresses above that temperature. This approximation was found to be acceptable for the cases given below, although thermal stressing could cause cracking in the regions where the glass is below the $500^{\circ} \mathrm{C}$, even if the center region is above $500^{\circ} \mathrm{C}$.

The "best estimate" for radial temperature difference is obtained by taking the algebraic difference between the upper and lower bounds of temperature difference obtained ahove. The reason is that, according to the quick-freeze model, the glass is unstressed as long as the temperature profile remains the same as that which existed when the residual stresses were created. Stresses will occur only when this profile is changed. Thus, if the radial temperature difference representing the residual stresses was $100^{\circ} \mathrm{C}$, for example, and the radial temperature difference was increased to $300^{\circ} \mathrm{C}$, the best-estimate temperature difference would be $300^{\circ} \mathrm{C}-100^{\circ} \mathrm{C}=200^{\circ} \mathrm{C}$. An assumption implicit to this approach is that cracking from residual and thermal stresses is equally proportional to radial temperature difference. The actual situation is more complex, since cracking may have occurred prior to the change in cooling conditions and since the temperature profile will not have the same shape as it would have during constant cooling. Nevertheless, this approach produced reasonable results, as is shown below.

Canister PS-17-4 was exposed to a nonsteady cooling regime in an attempt to minimize cracking by reducing the thermal gradients near the glass transition temperature. Peters and Slate (1981) covered canister PS-17-4 with relatively light insulation $(0.64-\mathrm{cm}$ ceramic board around the cooling pod) during the first hour. After the canister was filled, heavy insulation ( $8 \mathrm{~cm}$ thick around the pod) was applied, thereby reducing the gradients in the 
canister from $200^{\circ} \mathrm{C}$ to $40^{\circ} \mathrm{C}$ (Figure 4.5 ). After 3 hours, the heavy insulation was removed, and fast cooling was resumed with light insulation, as during the filling. As Figure 4.5 shows, the radial temperature difference increases to a maximum of $100^{\circ} \mathrm{C}$ when the centerline temperature has fallen to $500^{\circ} \mathrm{C}$. However, use of $100^{\circ} \mathrm{C}$ as an indication of the magnitude of residual stresses is inappropriate because most of the glass has undergone stress relief before the heavy

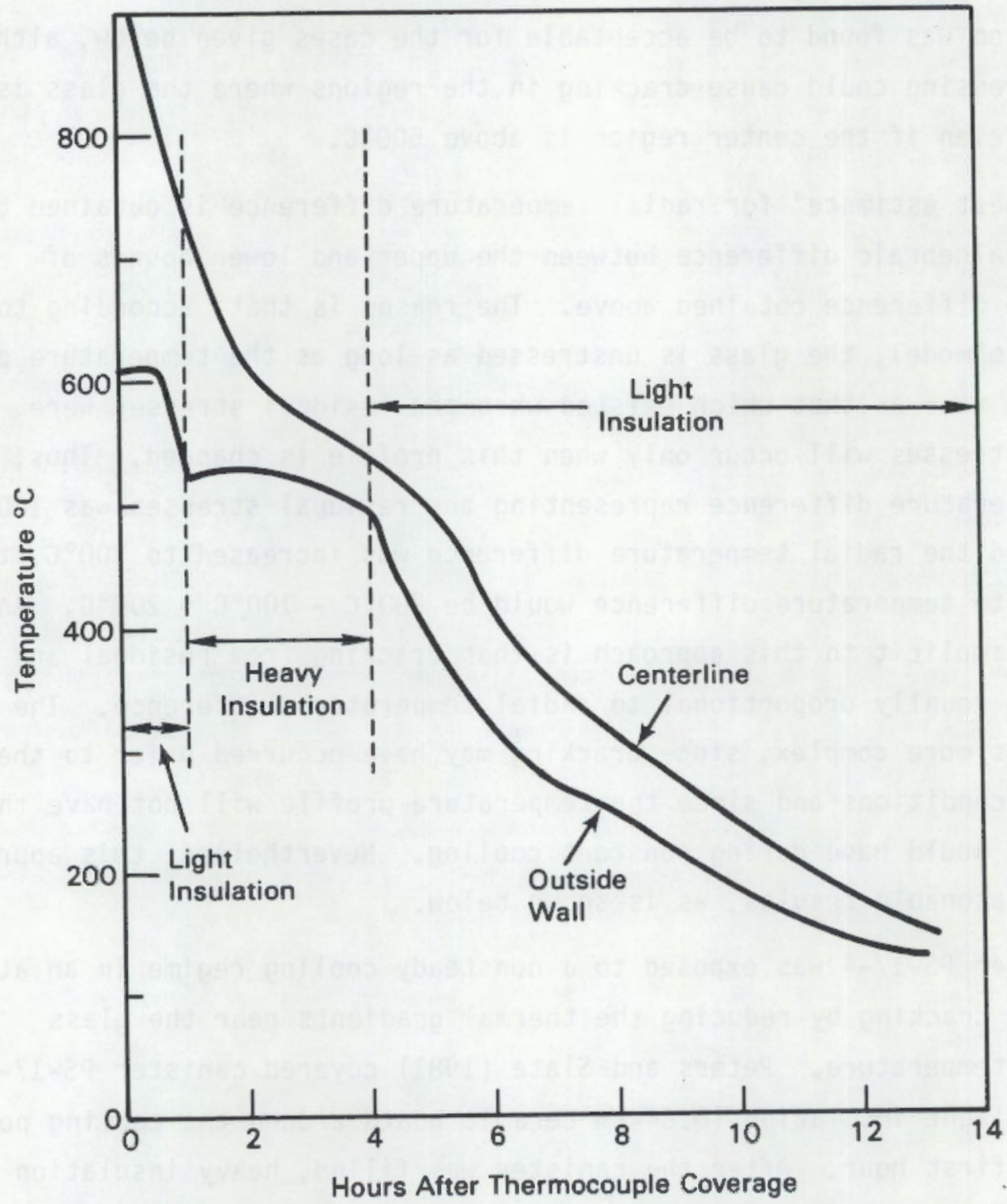

FIGURE 4.5. Centerline and Wall Temperatures During Multistaged Cooldown (Peters and Slate 1981) 
insulation was removed. Therefore, a radial temperature difference of about $40^{\circ} \mathrm{C}$, the value when the heavy insulation was removed, was judged to be appropriate for residual stresses. Thus, $40^{\circ} \mathrm{C}$ is taken as the lower limit for radial temperature difference (Figure 4.4 ).

The maximum value of radial temperature difference was obtained by determining the peak temperature difference that occurred during the rapid cooldown when the centerline temperature was at or below $500^{\circ} \mathrm{C}$. Figure 4.5 shows this peak to be $100^{\circ} \mathrm{C}$ when the centerline temperature was $500^{\circ} \mathrm{C}$. It was used as the upper limit of radial temperature difference. The best estimate is the difference between the upper and lower bounds, $100^{\circ} \mathrm{C}-40^{\circ} \mathrm{C}=60^{\circ} \mathrm{C}$. As Figure 4.4 shows, good agreement is obtained.

Canisters FCS-15-2 and FCS-15-3 were both water quenched when the surface temperature dropped to $350^{\circ} \mathrm{C}$. The temperature difference as a function of centerline temperature is given in Figure 4.6 . The radial temperature difference at a centerline temperature of $500^{\circ} \mathrm{C}$ is $450^{\circ} \mathrm{C}$. However, note that the radial temperature difference was only $230^{\circ} \mathrm{C}$ when the centerline temperature was $550^{\circ} \mathrm{C}$ prior to placing the canister in the water. Figure 4.7 gives the computed radial temperature distribution of the canister when the centerline temperature was $580^{\circ} \mathrm{C}$. To be conservative, rather than using $550^{\circ} \mathrm{C}$ as the centerline temperature per Figure 4.6 , a centerline temperature of $580^{\circ} \mathrm{C}$ was used. The $580^{\circ} \mathrm{C}$ value was obtained by adding the $230^{\circ} \mathrm{C}$ radial temperature difference to the $350^{\circ} \mathrm{C}$ surface temperature at which water quenching commenced. The transition temperature of the glass is about $510^{\circ} \mathrm{C}$. The outer half of the radius, comprising $75 \%$ of the glass, is below $510^{\circ} \mathrm{C}$, and has its residual stresses fixed because that part of the glass is effectively solid. Therefore, rapid cooling from the water quenching of this glass would not cause additional residual stresses. The remaining $25 \%$ of the glass experiences a relatively small temperature difference $\left(580^{\circ} \mathrm{C}-510^{\circ} \mathrm{C}\right)$. This $70^{\circ} \mathrm{C}$ difference will cause minimal residual stresses. In addition, initially little of the increased radial temperature difference from the water quenching is expressed in the center of the canister. Therefore, much of the inner $25 \%$ of the glass will have passed through the transition temperature before large, stress-causing temperature differences have reached that portion of the canister. Further 


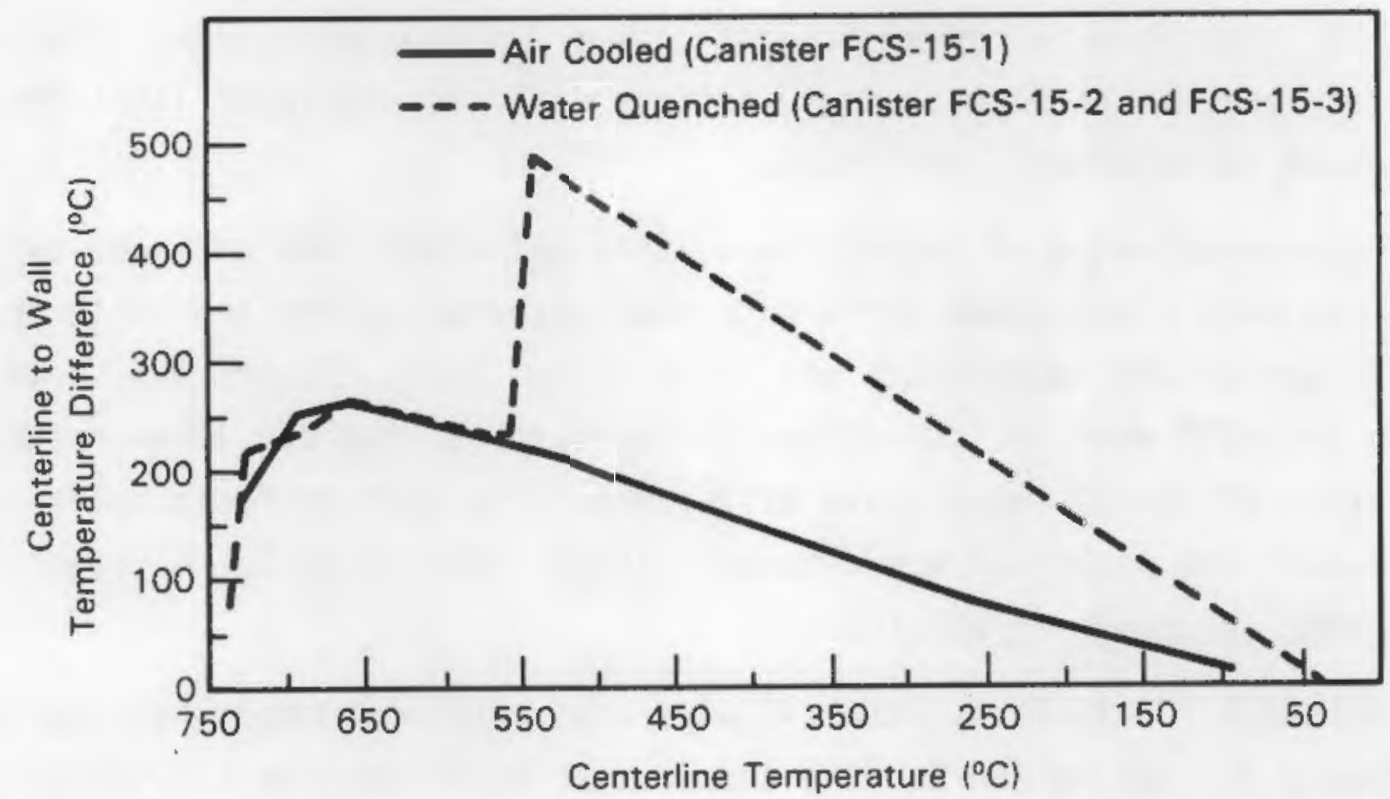

FIGURE 4.6. Comparison of Centerline Wall Temperature Differences During Cooling

analysis would be required to estimate this fraction accurately; a reasonable guess is that at most $10 \%$ of the glass would experience more strains and, hence, cracking than if the cooldown had been allowed to proceed without water quenching. The air-cooled curve on Figure 4.6 indicates a radial temperature difference of $200^{\circ} \mathrm{C}$ when the centerline temperature was $500^{\circ} \mathrm{C}$; therefore, a reasonable value to use for the radial temperature difference giving rise to residual stresses is slightly higher, about $220^{\circ} \mathrm{C}$. A conservative value of $200^{\circ} \mathrm{C}$ was used as a lower bound in Figure 4.4 for canisters FCS-15-2 and FCS-15-3.

The upper bound for the radial temperature difference is $500^{\circ} \mathrm{C}$ as that is the maximum radial temperature difference that occurred during the quenching process--this value is used in Figure 4.4 for those canisters. The "best value" is that obtained from taking the difference between $500^{\circ} \mathrm{C}$ and $200^{\circ} \mathrm{C}$; or $300^{\circ} \mathrm{C}$.

The points for FCS-15-2 and FCS-15-3 are plotted, in Figure 4.4, along with their uncertainties in relative area (from Table 4.2) and in temperature difference (as computed above). At first glance, the agreement seems marginal 


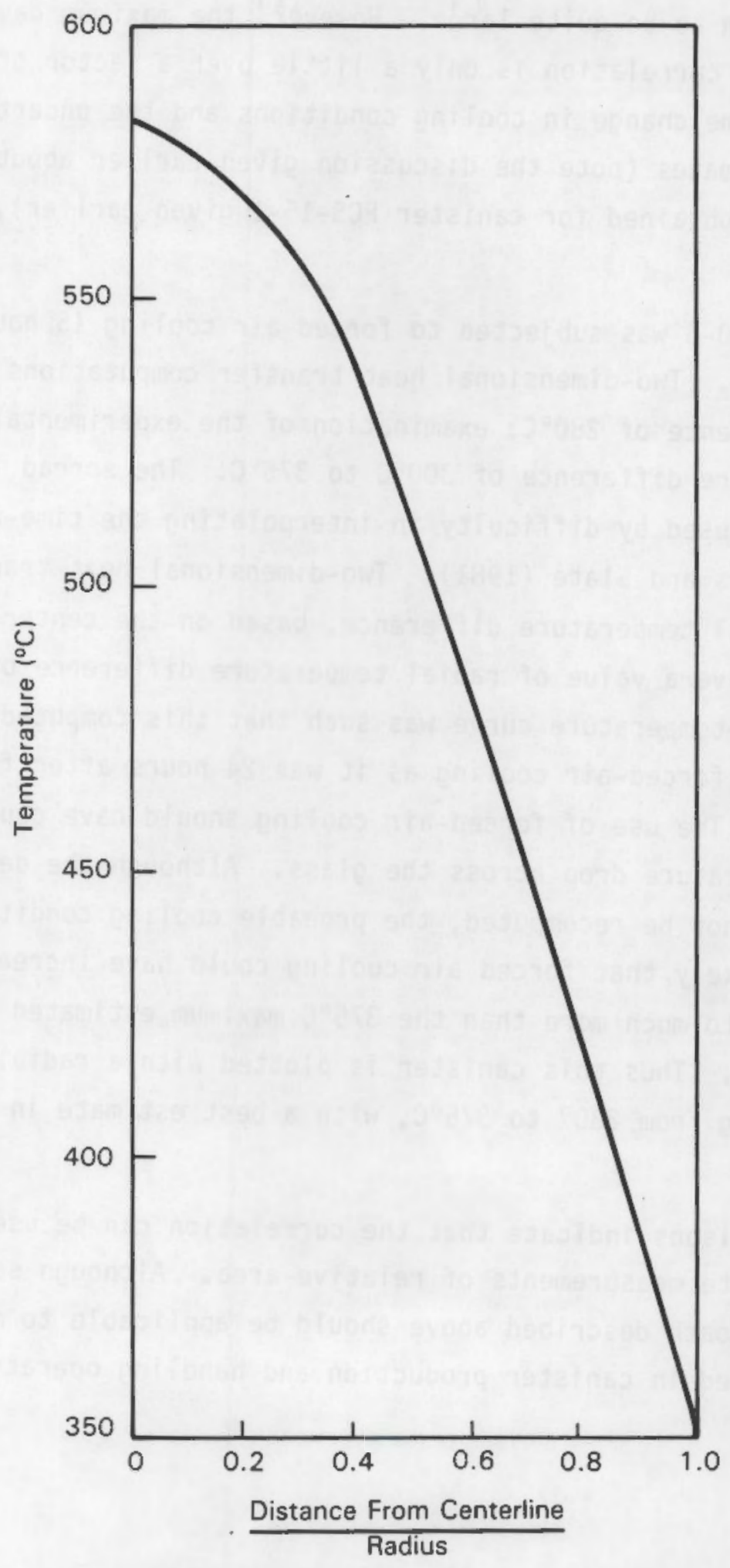

FIGURE 4.7. Computed Radial Temperature Distribution of Canister FCS-15-2 at Commencement of Water Quenching

$$
4.21
$$


and the bounds seem to be quite large. However, the maximum deviation in relative area from the correlation is only a little over a factor of two. Considering the extreme change in cooling conditions and the uncertainty in the relative-area estimates (note the discussion given earlier about the factor of two higher values obtained for canister FCS-15-1 given earlier), the agreement is very good.

Canister PS-60-3 was subjected to forced-air cooling 15 hours after filling was completed. Two-dimensional heat transfer computations gave a radial temperature difference of $280^{\circ} \mathrm{C}$; examination of the experimental data indicated a radial temperature difference of $300^{\circ} \mathrm{C}$ to $375^{\circ} \mathrm{C}$. The spread in the experimental data was caused by difficulty in interpolating the time-temperature data presented in Peters and Slate (1981). Two-dimensional heat transfer computations of the radial temperature difference, based on the centerline temperature-time data, gave a value of radial temperature difference of $280^{\circ} \mathrm{C}$. The shape of the time-temperature curve was such that this computed difference was the same prior to forced-air cooling as it was 24 hours after forced-air cooling started. The use of forced-air cooling should have caused some increase in temperature drop across the glass. Although the details of the heat transfer cannot be recomputed, the probable cooling conditions were such that it is not likely that forced air cooling could have increased the temperature drop to much more than the $375^{\circ} \mathrm{C}$ maximum estimated from the experimental data. Thus this canister is plotted with a radial temperature difference ranging from $280^{\circ}$ to $375^{\circ} \mathrm{C}$, with a best estimate in the middle of this range.

These comparisons indicate that the correlation can be used to obtain reasonably accurate measurements of relative area. Although some judgment must be used, the approach described above should be applicable to most of the transients expected in canister production and handling operations. 


\subsection{DISCUSSION}

The correlation presented in Section 4.0 represents a significant advance in the ability to predict the amount of surface area created by cracking. This correlation allows the prediction of cracking to within the limits of the accuracy of the experimental data over a four-fold range of canister sizes and over a wide range of casting and cooling conditions. The correlation is easy to apply since the radial temperature difference can be either measured experimentally or, in many situations, computed in a straightforward manner. Development of this correlation represents a significant advance in that much better estimates can be made of the amount of glass surface area within a canister than before. Although the correlation is useful for scoping purposes, there is a need to validate the correlation against additional canister cracking data, particularly in the case of stainless steel canisters. It is possible that such data are available but have not been published. If they exist and can be reliably retrieved, they should be used to help validate the correlation. Aside from the paucity of data, the accuracy of the surface area estimates is the limiting item for predicting cracking, so future studies of cracking should aim at improving these estimates.

As stated above, the correlation should be easy to use for most cooling conditions. All that is needed is an estimate of the radial temperature difference at $500^{\circ} \mathrm{C}$. The radial temperature differences used for developing the correlation were obtained from experimental data and from two-dimensional heat transfer analyses using centerline temperature-time data. In addition, the predictions of the two-dimensional computations were compared to experimental data wherever possible. Good agreement was obtained between these experimental and computed temperature differences. Thus a two-dimensional computation will, in most cases, suffice to predict cracking area, providing that the heat transfer resistances are properly computed. The computation must include taking into account the nonlinear heat transfer resistances for thermal radiation resulting from the fourth power of temperature dependence. A value of the radiation effects computed for the condition when the centerline temperature is 
at $500^{\circ} \mathrm{C}$ should suffice because that assumption is consistent with the abovementioned two-dimensional computations, which were used to obtain the correlation.

Therefore, as long as the pouring times and the length-to-diameter ratio of the glass in the canister are within the range found for the canisters presented on Table 4.1 , the correlation should give good results with twodimensional heat transfer computations. Situations where the cooling conditions are changed during cooldown can be accommodated by using judgment; examples are given in Section 4.0. For difficult situations, computer codes such as TEMPEST can be used to obtain the thermal conditions near the transition temperature. If the radial temperature drop in the transition region var.. ies significantly along the length of the canister, reasonable results can probably be obtained by summing weighted values of relative surface areas obtained as a function of axial location. (It should be remembered that end effects caused changes in the radial temperature difference in the canisters upon which the correlation was based.)

\section{APPLICATION OF CORRELATION TO HIGH-OECAY HEAT GLASSES}

The cracking correlation given in Figure 4.1 was based on data obtained for nonradioactive glasses; no temperature gradient existed once those canisters had cooled to ambient. Thus it was proper to use $\Delta T_{r}$ as the independent variable for the correlation. The appropriate independent variable for the more general case (which includes internal heat production) is to use the difference between the radial temperature difference at $500^{\circ} \mathrm{C}$ and the steady-state radial temperature difference. (a) If we call the steady-state temperature dif. ference $\Delta T_{r}^{\prime}$ then the proper independent variable for the correlation is the quantity $\Delta T_{r}-\Delta T_{r}^{\prime}$. The general equations for the correlation are, therefore,

$$
\begin{gathered}
R A=1.0 \text { for }\left(\Delta T_{r}-\Delta T_{r}^{\prime}\right)>30^{\circ} \mathrm{C} \\
R A=1.0+0.10\left(\Delta T_{r}-\Delta T_{r}^{\prime}\right) \text { for }\left(\Delta T_{r}-\Delta T_{r}^{\prime}\right)>30^{\circ} \mathrm{C}
\end{gathered}
$$

(a) See the discussion on stresses in radioactive glass in Section 2.0 . 
for the case of carbon steel canisters

$$
\begin{gathered}
R A=1.0\left(\Delta T_{r}-\Delta T_{r}^{\prime}\right)<30^{\circ} \mathrm{C} \\
R A=1.0+0.23\left(\Delta T_{r}-\Delta T_{r}^{\prime}\right)>30^{\circ} \mathrm{C}
\end{gathered}
$$

for the case of stainless steel canisters, where

RA = the relative surface area, dimensiontess

$\Delta T_{r}=$ the radial temperature difference when the canister centerline is at $500^{\circ} \mathrm{C}$

$\Delta T_{r}^{\prime}=$ the steady-state radial temperature difference.

As the radioactivity decays, $\Delta T_{r}^{\prime}$ will approach zero. Thus the use of the equations given above implies that the amount of cracking will increase as $\Delta T_{r}^{\prime}$ decreases. However, this may not be the case if significant relief of residual stresses occurs due to creep.

\section{FUTURE CRACKING STUDIES}

As mentioned in Section 4.0, the use of Fiberfrax liners in stainless steel canisters appears to greatly reduce the amount of fines. In the one case where the value of $\Delta T_{r}$ was sufficiently high that the stainless steel correlation predicted sufficiently more cracking than the carbon steel correlation, the Fiberfrax-lined canister exhibited about half of the relative surface expected for unlined stainless steel.

In addition to greatly reducing the number of small particles, computations conducted at PNL show that Fiberfrax significantly reduces the thermal shock associated with post-filling decontamination of the canister in aqueous solutions. Although these results are promising, further studies are needed where canisters with and without Fiberfrax or other candidate liners are filled under identical conditions at the same pour rates and the same external thermal resistances, in order to verify the advantages of such liners.

The thermal resistance of Fiberfrax results in slower canister cooldown and in higher steady-state glass temperatures. Thus, one possible disadvantage 
of using a liner for extremely high-heat canisters or for glasses that are prone to devitrification is that the liner may cause unacceptably slow cooling or unacceptably high steady-state temperatures. While such concerns must be addressed, the heat loadings of many proposed waste forms are such that use of Fiberfrax liners will have negligible effect. For example, in experiments with a relatively high-heat loading glass $(28 \mathrm{~W} / \mathrm{L})$ in canisters of $30-\mathrm{cm}$ diameter and $100-\mathrm{cm}$ length with $0.32-\mathrm{cm}$ liners, steady-state temperature drops of $110^{\circ} \mathrm{C}$ or less across the liner were observed $\left(70^{\circ} \mathrm{C}\right.$ at the top and bottom with a maximum of $110^{\circ} \mathrm{C}$ at the center). This temperature drop is acceptable because it is but a fraction of the total centerline-to-ambient temperature. The temperature drop across the liner was even a smaller fraction of the total temperature dros during the filling process because of the thermal resistances of the LFCM components surrounding the canister. This example implies that in most cases Fiberfrax would not adversely affect the glass properties; if an analysis for another case indicates that it would, then reducing the liner thickness to $0.16 \mathrm{~cm}$ should be considered.

Aside from the paucity of data there are a number of reasons for conducting additional studies on unlined canisters. First, there is a reasonable chance that much of the observed cracking, particularly with slow-cooled canisters, occurs as a result of the dismantling process a crack initiation point was found at the saw cut interface during a brief inspection of one of the Fiberfrax-lined canisters). Second, there is considerable uncertainty about the relative accuracy of the different methods of estimating surface areas. For example, it is entirely possible that the spherical bursts described in Section 3.0 could result, at least in part, from the change in the stress field caused by cutting. A radial cut will eliminate all axial (tensile or compressive) stresses and all shear stresses at the glass interface; a longitudinal cut will eliminate shear stresses and all hoop stresses at the interface. The resulting change in stress fields almost certainly creates additional cracking. These changes in stress fields could cause much of the cracking (particularly bulk cracking) that is observed in slow-cooled canisters.

Third, further investigation is needed to determine whether or not batch filling affects the amount of cracking. Finally, instrumentation of canisters 
to determine the time-temperature fields and to accurately determine the glass height as a function of filling time is necessary, not only for the purposes of obtaining information needed to determine cracking as a function of filling and cooling conditions, but also to validate computer codes used for thermal computations.

For the reasons outlined above, future cracking studies should include the following elements:

- estimation of crack area by redundant methods (such as by the fiduciary line-intersect method and by particle size analysis). This will provide a measure of the uncertainty in the area estimates and will permit the use of existing data

- nondestructive testing prior to dismantling, in order to determine the extent of glass cracking caused by sectioning and dismanting

- redundant and precise means of determining the height of glass within the canister during filling so that the effects of changes in the filling rate can be made

- instrumentation that will permit accurate mapping of the thermal field during filling and cooidown

- determination whether or not systematic studies are needed to ascertain the sensitivity of cracking to glass composition.

Computerized tomography (Reimers 1981; Reimers and Goebbels 1982) is a promising method for conducting nondestructive testing. Some limited studies of this technique are being carried out by Kah1 (1985). Unfortunately, the results obtained to date indicate that resolution is insufficient to locate fine cracks nondestructively. Further evaluation of this method is warranted; a worthwhile experiment would be to make up canisters with simulated cracks of various gap sizes and orientations. These would be examined to determine how well tomography identifies the cracks. 
EFFECTS OF CRACKING ON RADIONUCLIDE RELEASE

The computation of the radionuclide release from a waste glass canister to the biosphere is a complex subject that is beyond the scope of this study. However, because the use of crack surface area, per se, can lead to erroneously high estimates of radionuclide release, it is appropriate to discuss the topic here. There are many resistances to the transport of the radionuclides to the environment; the release from the glass is only one of many. Even without these other resistances to radionuclide transport, the use of surface area to estimate radionuclide release would still lead to erroneously high estimates. There are several reasons:

- Most of the surface area is associated with only a small fraction of the mass of the glass and therefore the mass of the radionuclides. For example, for stainless steel canister FCS-15-3, 50\% of the surface area was found on particles less than $3 \mathrm{~mm}$, which made up only $4 \%$ of the mass. For carbon steel canisters, $50 \%$ of the area was found on particles less than $8 \mathrm{~mm}$ in diameter, which again made up $4 \%$ of the mass. Once this fraction of the glass is dissolved, the relative surface area is significantly decreased.

- Some of the crack area is physically isolated from the outside of the canister by the surrounding glass and, therefore, would not be exposed to groundwater even after a significant fraction of the glass had been leached away. For example, the methods of area estimation in use today effectively treat casting voids as crack surface area. In other cases, crack areas exist that probably do not intersect any cracks that reach the surface.

- The mass transfer resistances resulting from the narrow, tortuous paths formed by the cracks could significantly reduce the release of radionuclides (Perez and Westsik 1981), compared to that from an exposed surface of the same area. 


\subsection{CONCLUSIONS AND RECOMMENDATIONS}

A correlation has been developed that predicts the surface area created by cracking to within the accuracy of the existing data. The correlation is a simple linear equation; the surface area can be computed from a knowledge of the steady-state radial temperature difference and the radial temperature difference when the glass centerline temperature was at $500^{\circ} \mathrm{C}$. This correlation should be easy to use for waste glass canister applications since, in many cases, a two-dimensional heat transfer analysis can be used to determine the radial temperature differences. Although the correlation is useful for scoping purposes, there is a need to validate the correlation against additional canister cracking data, particularly in the case of stainless steel canisters.

The use of Fiberfrax liners deserves serious consideration for use in stainless steel waste glass canisters. (a) The amount of cracking is reduced because the liner eliminates the metal-glass interactions that produce significant stresses in the glass. Another less obvious, but very important, advantage of using Fiberfrax is that thermal shocking during decontamination and post-fill operations is reduced because of the liner's insulating capacity. More extensive studies to verify these results are recommended; canisters should be produced, under identical cooling conditions, that differ only in the use of liners.

The data for any canister type are extremely sparse, and there is considerable uncertainty about the accuracy of the different methods that have used to obtain surface area estimates. The comparative roles played by batch and continuous filling of the canisters also need to be clarified.

(a) As mentioned in the previous section, one possible (though not likely) disadvantage for extremely high-heat canisters, or for glasses that are prone to devitrification, is that the liner may cause unacceptably slow cooling or unacceptably high steady-state temperatures. These concerns must be addressed on a case-by-case basis; in the event that the liner's thermal resistance is too high, use of a thinner liner than the $0.32-\mathrm{cm}-$ thick liners studied here should be considered. 
Furthermore, there is a need for accurate thermal data to validate computer codes for determining the temperature histories of canisters. Therefore, future cracking studies should include the following:

- estimation of crack area by redundant methods (such as by the fiduciary line-intersect method and by particle size analysis). This witl provide a measure of the uncertainty in the area estimates and will permit the use of existing data.

- nondestructive testing prior to dismantling to determine the extent of glass cracking caused by sectioning and dismantling

- redundant and precise means of determining the height of glass within the canister during filling so that the effects of changes in the filling rate can be made

- instrumentation that will permit accurate mapping of the thermal field during filling and cooldown. 


\subsection{REFERENCES}

Farnsworth, R. K., M. K. W. Chan, and S. C. Slate. 1984. "The Effects of Radial Temperature Gradients on Glass Fracture in Simulated High-Level Waste Canisters." Scientific Basis for Nuclear Waste Management VIII, pp. 831-838. Symposium proceedings, Materials Research Society, Pittsburgh, Pennsylvania.

Kahl, L. 1985. The Performance of Soljdified High-Level Waste Forms and Engineered Barriers Under Repository Conditions. International Atomic Energy Agency First Research Coordination Meeting, Japan Atomic Energy Research Institute, Tokyo.

Kamizono, $H_{.}$, and K. Niwa. 1984. "An Estimation of the Thermal Shock Resistance of Simulated Nuclear Waste Glass Inder Water Quenching Conditions." Journal of Materials Science Letters 3:588-590.

Kamizono, H., and M. Senoo. 1983. "Thermal Shock Resistance of a Simulated High-Level Waste Glass." Nuclear and Chemical Waste Management 4:329-333.

Kreith, F. 1973. Principles of Heat Transfer, 3rd Edition. Harper \& Row, New York.

Laude, F., F. Vernaz, and M. Saint-Gaudens. 1982. "Fracture Appraisal of Large-Scale Glass Blocks Inder Realistic Thermal Conditions." Scientific Basis for Nonradioactive Waste Management, Vol. 5, en. W. Lutze, ETsevier Science Publishing Co., Amsterdam.

Martin, D. M. 1985. Fracture in Glass/High Level Waste Canisters. NUREG/CR-4198, by Iowa State IIniversity for II.S. Nuclear Regulatory Commission, Washington D.C.

Perez, J. M., Jr., and J. H. Westsik, Jr. 1981. "Effects of Cracks on GilassLeaching." Nuclear and Chemical Waste Management 2:165-168.

Peters, R. D., and S. C. Slate. 1981. "Fracturing of Simulated High-Level Waste Glass in Canisters." Nuclear Engineering and Design 67:425-445.

Reimers, P., and J. Goebbels. 1983. "New Possibilities of Nondestructive Evaluation by X-ray Computed Tomography." Materials Evaluation 41:732.

Reimers, P., W. B. Gilboy, and J. Goebbels. 1984. "Recent Developments in the Industrial Application of Computerized Tomography with Ionizing Radiation." NDT Internationa1 17:199.

Simonen, F. A., and S. C. Slate. 1979. Stress Analysis of High-Level Waste Canisters: Methods, Applications, and Design Oata. PNL-3n36, Pacific Northwest Laboratory, Richland, Washington. 
Slate, S. C., L. R. Bunnell, W. A. Ross, F. A. Simonen, and J. H. Westsik, Jr. 1978. "Stress and Cracking in High-Level Waste Glass." In High-level Radioactive Solid Waste Forms, pp. 393-450 NUREG/CR-0005. U.S. NucTear Regulatory Commission, Washington, D.C.

Smith, P. K., and C. A. Baxter. 1981. Fracture During Cooling of Cast Borosilicate Glass Containing Nuclear Wastes. DP-1602, E. I. du Pont de Nemours \& Co., Savannah River Laboratory, Aiken, South Carolina.

Smith, P. K., and J. R. Wiley. 1980. "Thermal Fracturing in Glass Waste Forms." DP-MA-80-61, E. I. du Pont de Nemours \& Co., Savannah River Laboratory, Aiken, South Carolina.

Timoshenko, S., and D. H. Young. 1962. Elements of Strength of Materials. D. Van Nostrand Company, Inc., Princeton, New Jersey.

Tooley, F. V. 1974. The Handbook of Glass Manufacture. Books for Industry, Inc. New York. 
APPENDIX A

CANISTER DISMANTLING DATA 


\section{APPENDIX A}

\section{CANISTER DISMANTLING DATA}

In Tables A.l through A.4, the weights of each piece of glass that was taken from the canister is listed under WEIGHT. This list was divided into the following weight groups:

- greater than 5000 grams each

- between 1000 and 5000 grams each

- between 500 and 1000 grams each

- between 250 and 500 grams each

- between 100 and 250 grams each

- total of pieces between 50 and 100 grams each

- total of pieces less than 50 grams each.

The sum of each weight division is listed in the second column with the percentage of each being 1 isted under $\not$. The diameter of a sphere having the weight of the listed particle is given in the fourth column. The surface area of that sphere is given in the fifth column. The adjusted surface area was determined by multiplying the sphere surface by the factor listed for each weight group. 
TABLE A.1. Canister 2, Top Quarter (2/1) Glass Particle Distribution

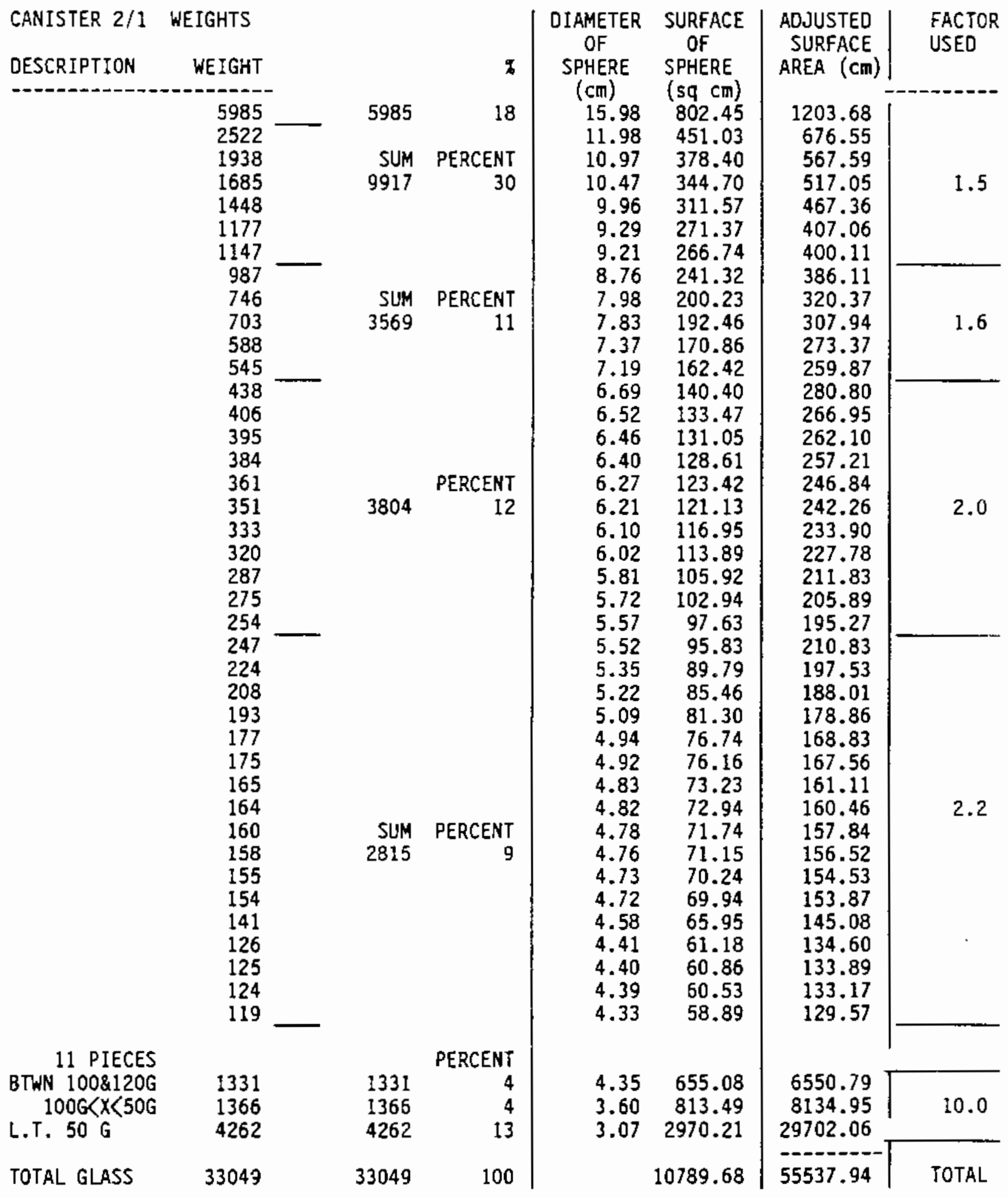

\footnotetext{
(a) Assumed glass density of $2.8 \mathrm{~g} / \mathrm{cc}$. This is the diameter of a sphere of glass weighing what the piece weighed.

(b) Surface area of the sphere multiplied by the factor given to give a better
estimate of surface area.
} 
TABLE A.2. Canister 2, Bottom Quarter (2/4) Glass Particle Distribution CANISTER $2 / 4$ WEIGHTS

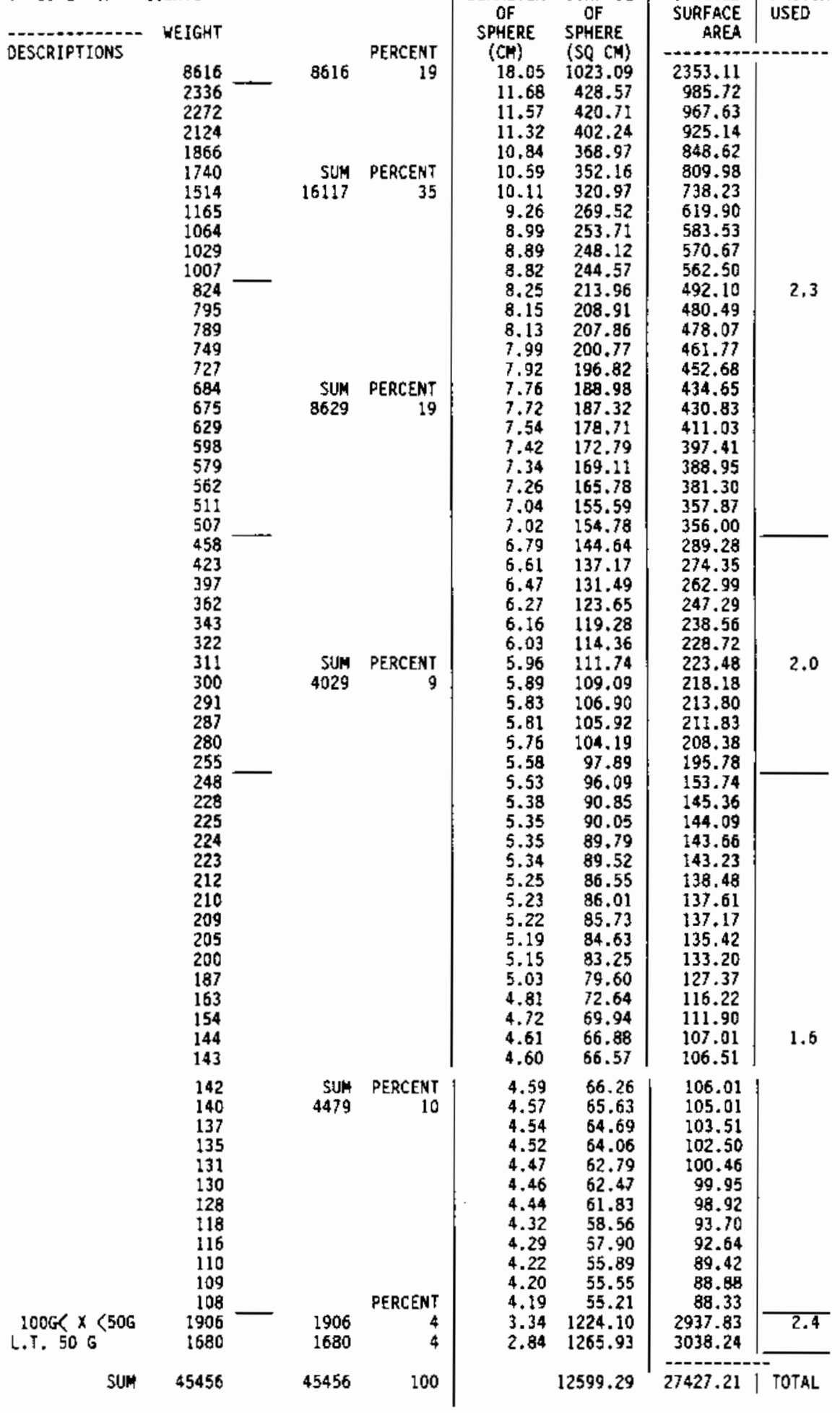

(a) Assumed glass density of $2.8 \mathrm{~g} / \mathrm{cc}$. Th1s is the diameter of a sphere of glass weighing what the piece weighed.

(b) Surface area of the sphere multiplied by the factor given to give better estimate of surface area. 
TABLE A.3. Canister 7, Top Quarter (7/1) Glass Particle Distribution

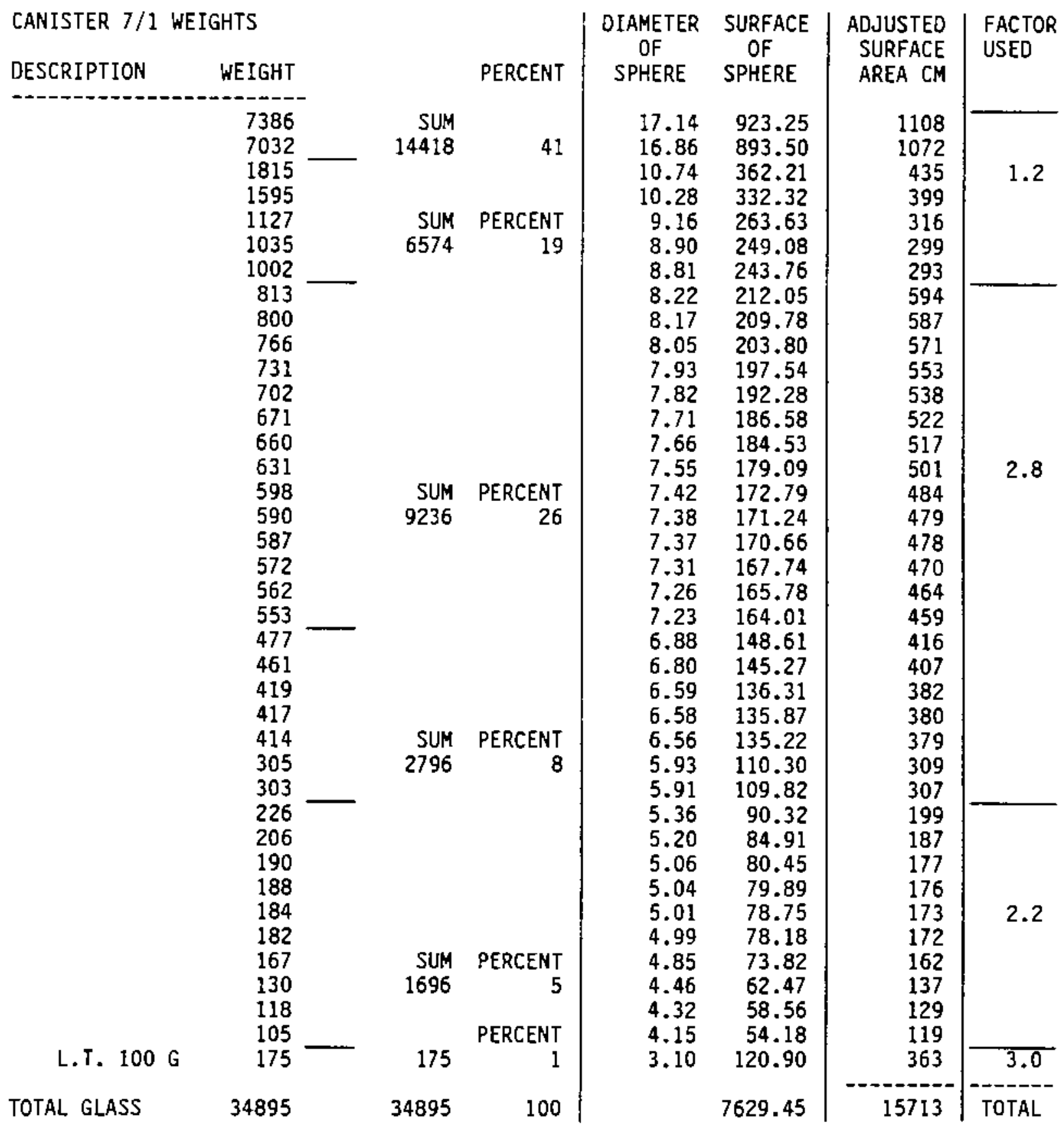


TABLE A.4. Canister 7, Bottom Quarter (7/3) Glass Particle Distribution

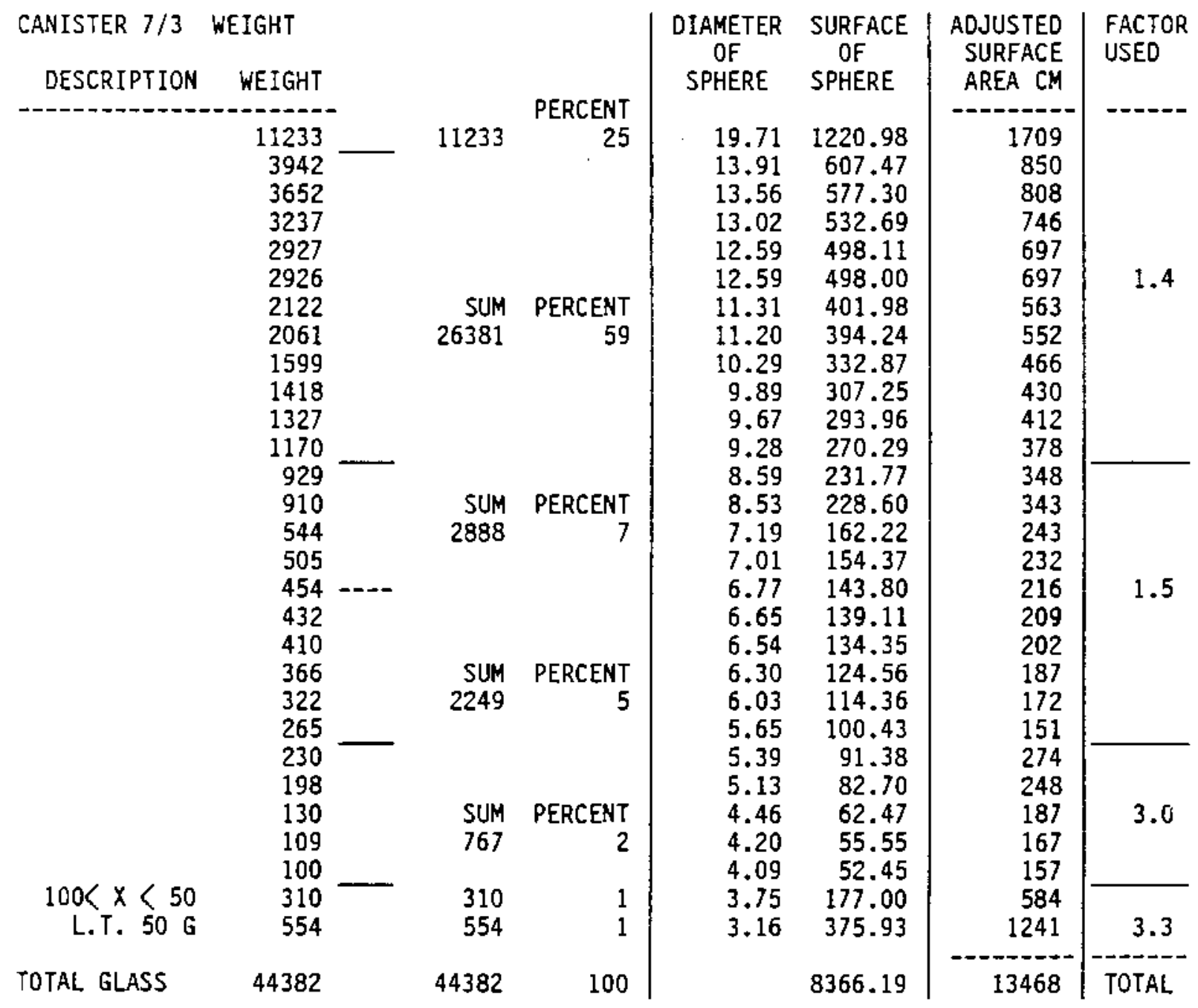

(a) Assumed glass density of $2.8 \mathrm{~g} / \mathrm{cc}$. This is the diameter of a sphere of glass weighing what the piece weighed.

(b) Surface area of the sphere multipilied by the factor given to give a better estimate of surface area. 
$\because$ 
APPENDIX B

PHOTOGRAPHS OF CANISTERS 
TABLE B.1. Canister Descriptions

\begin{tabular}{|c|c|c|c|c|}
\hline $\begin{array}{c}\text { Canister } \\
\text { Number }\end{array}$ & $\begin{array}{c}\text { Number of } \\
\text { Pours }\end{array}$ & Instrumentation & $\begin{array}{c}\text { External } \\
\text { Insulation } \\
\end{array}$ & Comments \\
\hline 1 & 3 & $\begin{array}{l}30 \text { external } \\
\text { thermocouples } \\
\text { (TCS) }\end{array}$ & None & $\begin{array}{l}\text { Filled within } \\
\text { turntable } \\
\text { simulant }\end{array}$ \\
\hline 2 & 3 & $\begin{array}{l}8 \text { external TCs } \\
22 \text { internal TCs }\end{array}$ & $1 / 4$ inch & \\
\hline 3 & 6 & $\begin{array}{l}7 \text { external TCs } \\
23 \text { internal TCs }\end{array}$ & $1 / 4$ inch & \\
\hline 4 & $\begin{array}{l}3 \\
\text { interrupted }\end{array}$ & $\begin{array}{l}8 \text { external TCs } \\
22 \text { internal TCs }\end{array}$ & 3 inches & \\
\hline 5 & 3 & 30 external TCs & None & $\begin{array}{l}\text { Filled within } \\
\text { turntable } \\
\text { simulant }\end{array}$ \\
\hline 6 & 3 & None & 3 inches & \\
\hline 7 & 6 & $\begin{array}{l}7 \text { external TCs } \\
23 \text { internal TCs }\end{array}$ & 3 inches & \\
\hline 8 & 3 & None & $1 / 4$ inch & \\
\hline
\end{tabular}




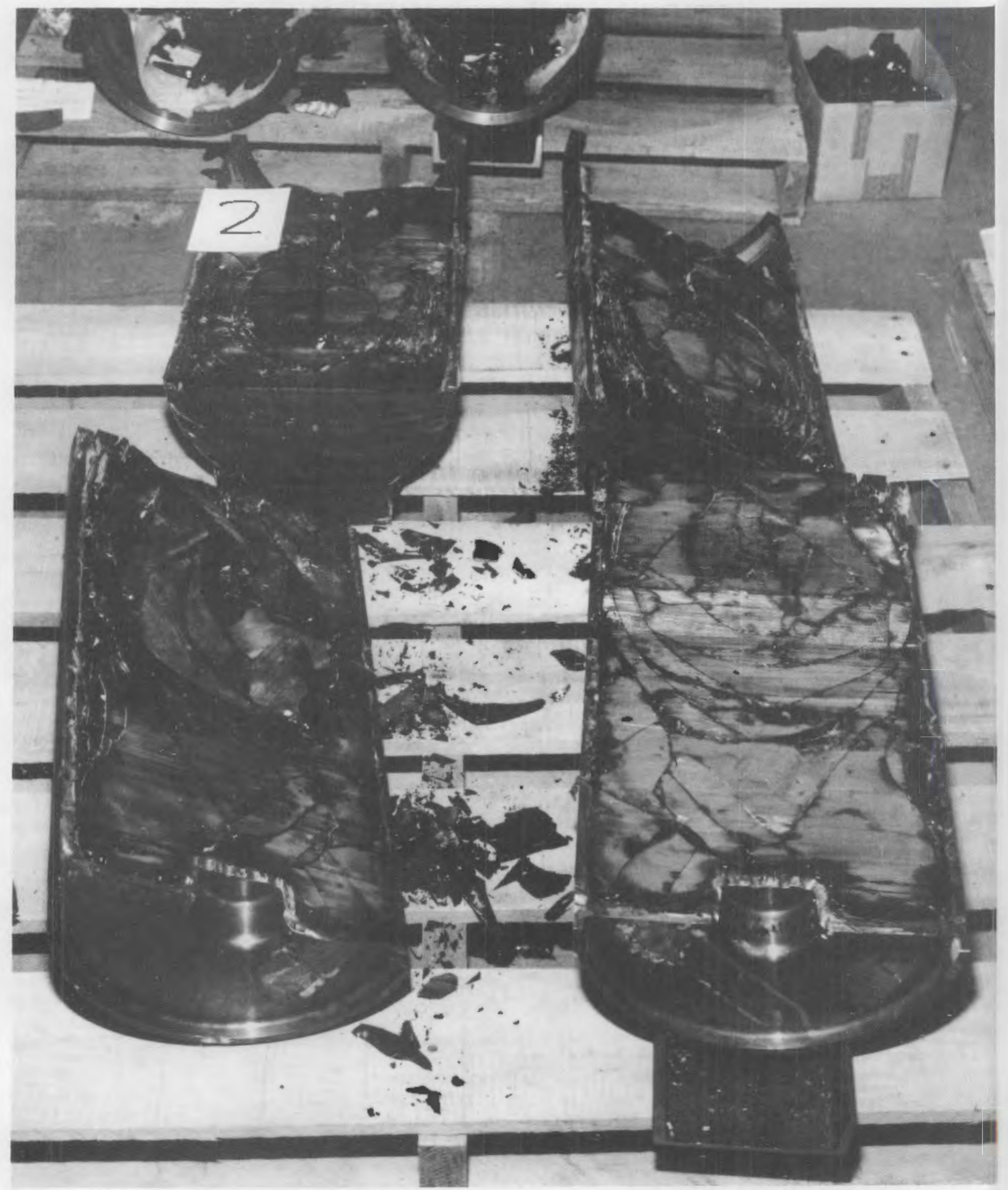

FIGURE B.1. Canister \#2 


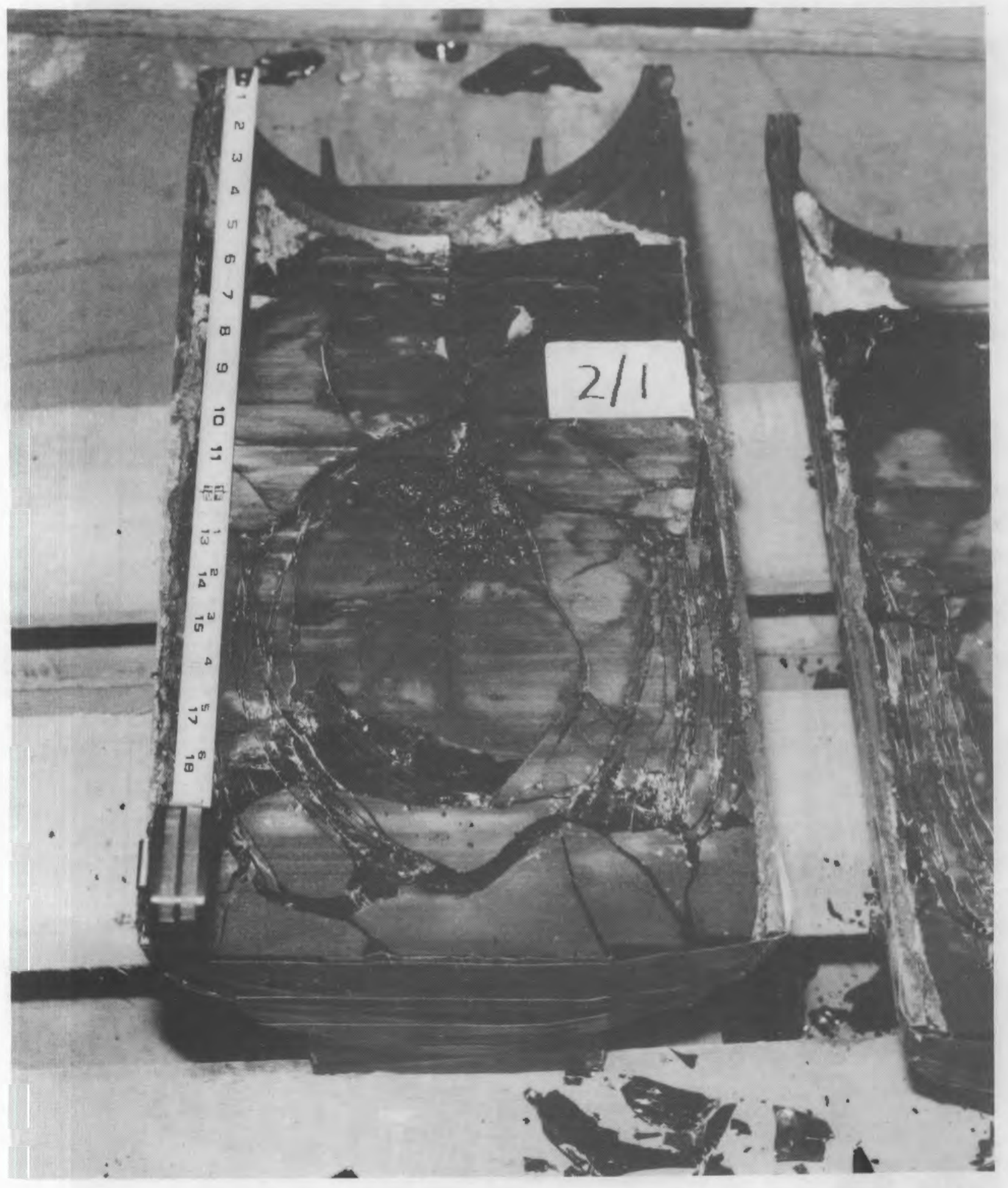

FIGURE B.2. Canister \#2, Part $1(2 / 1)$ 


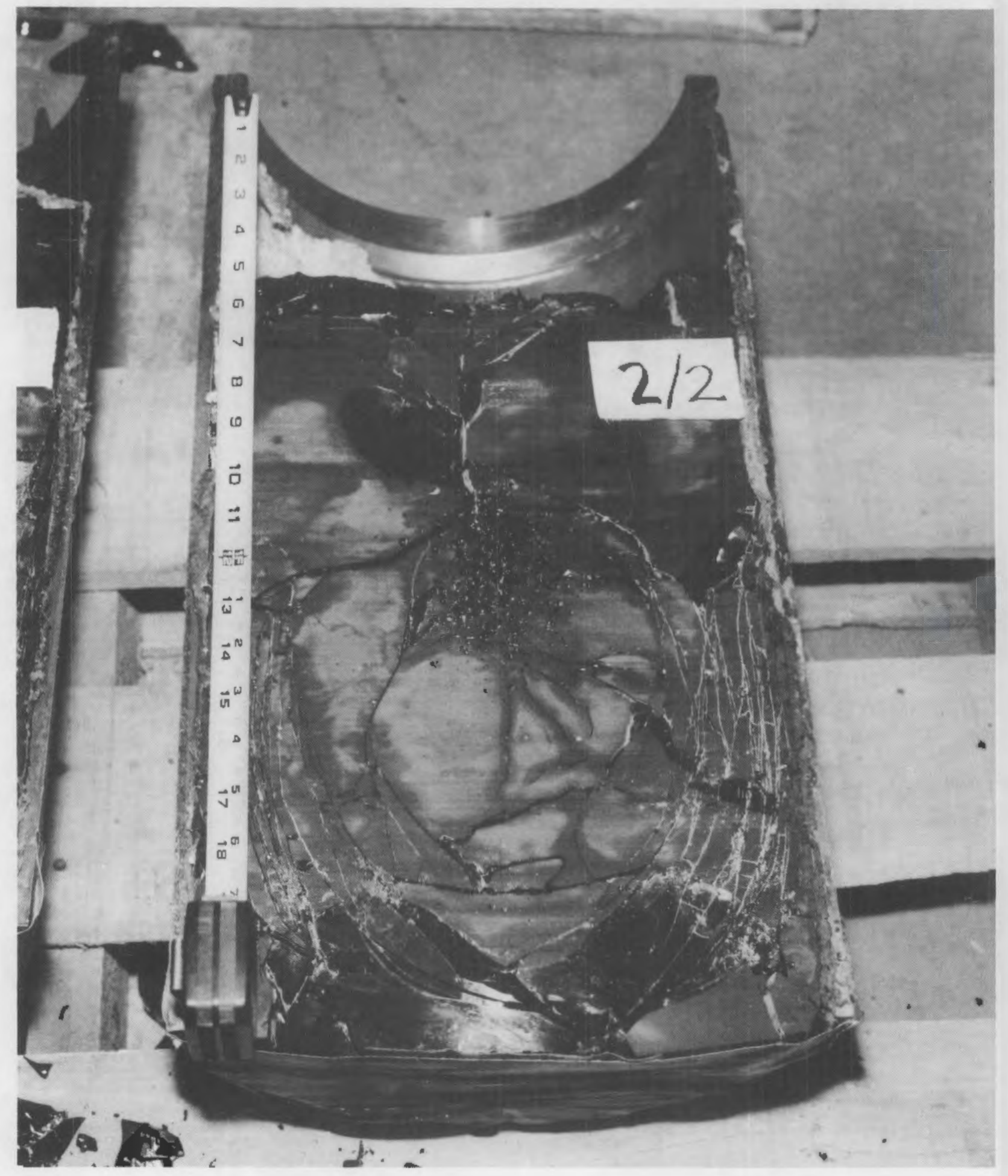

FIGURE B.3. Canister \#2, Part 2 (2/2) 


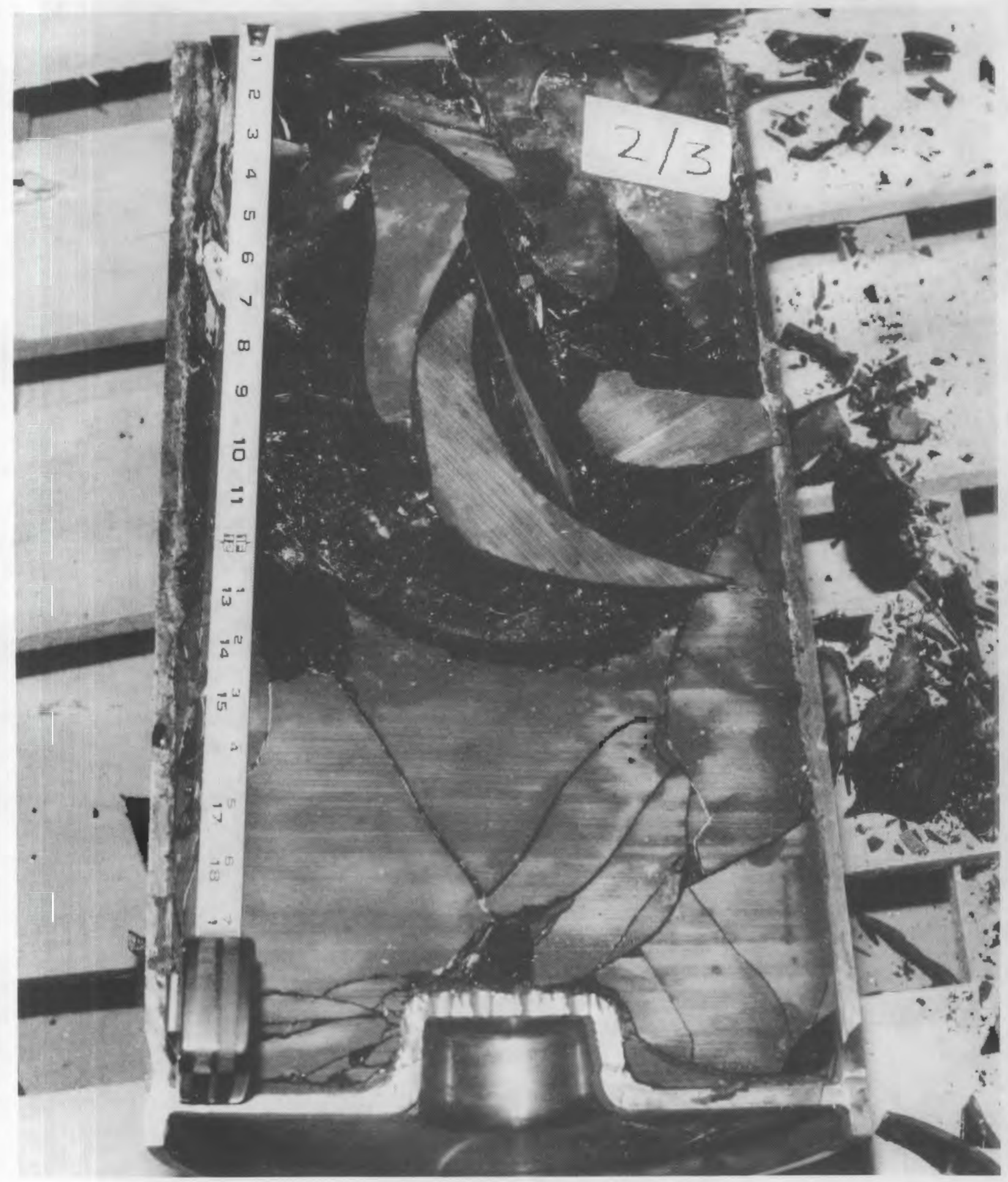

FIGURE B.4. Canister \#2, Part $3(2 / 3)$ 


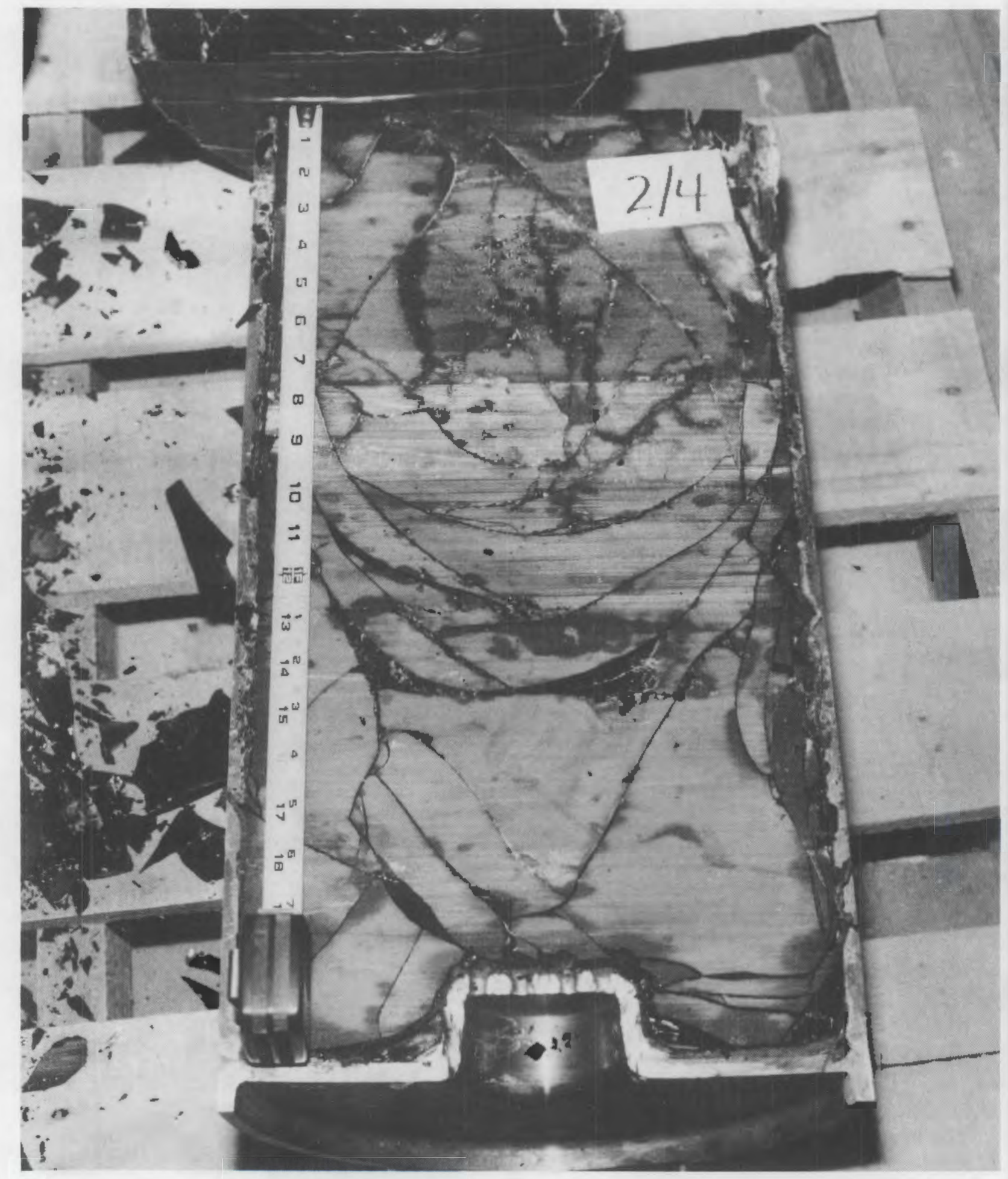

FIGURE B.5. Canister \#2, Part $4(2 / 4)$ 


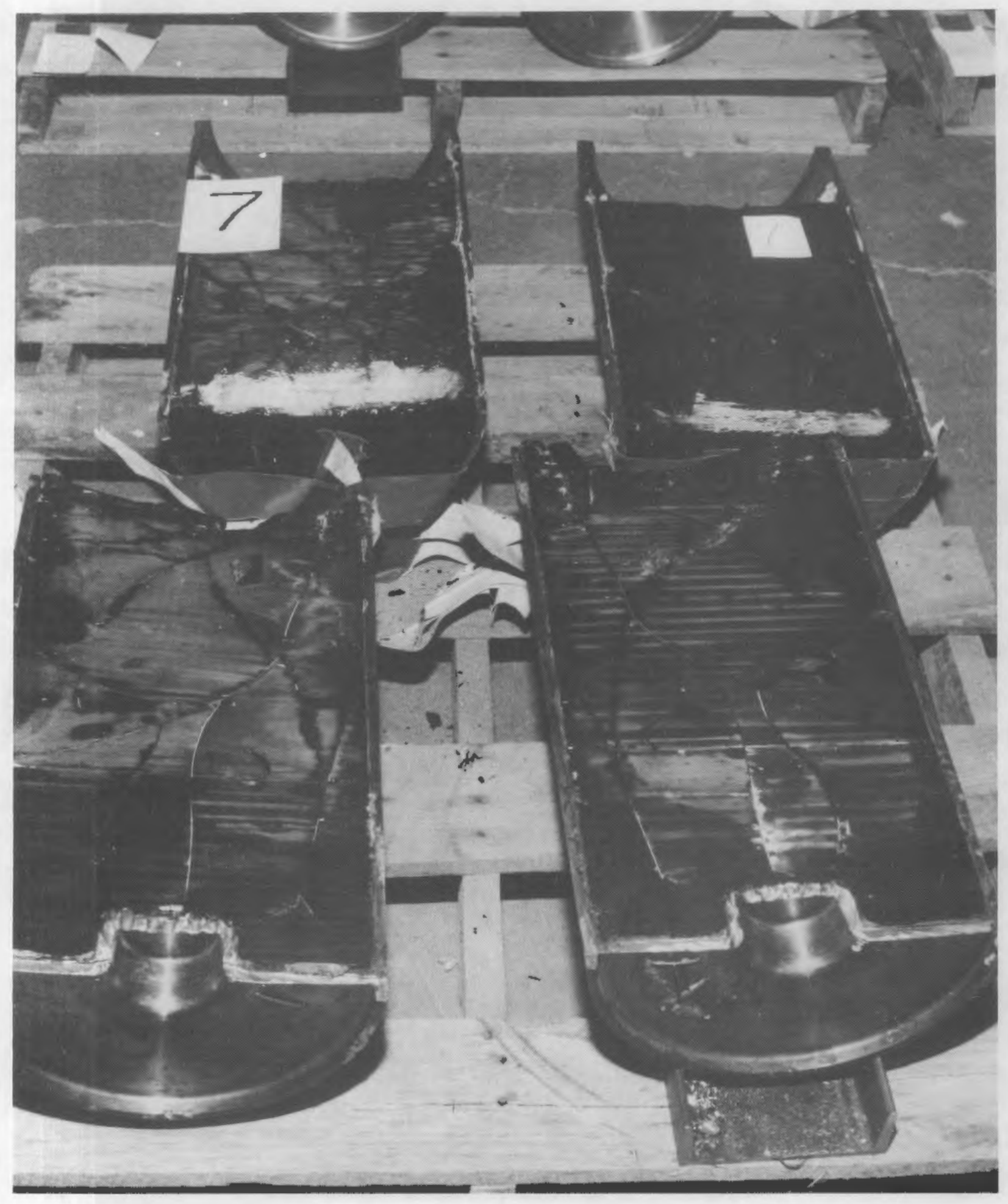

FIGURE B.6. Canister \#7 


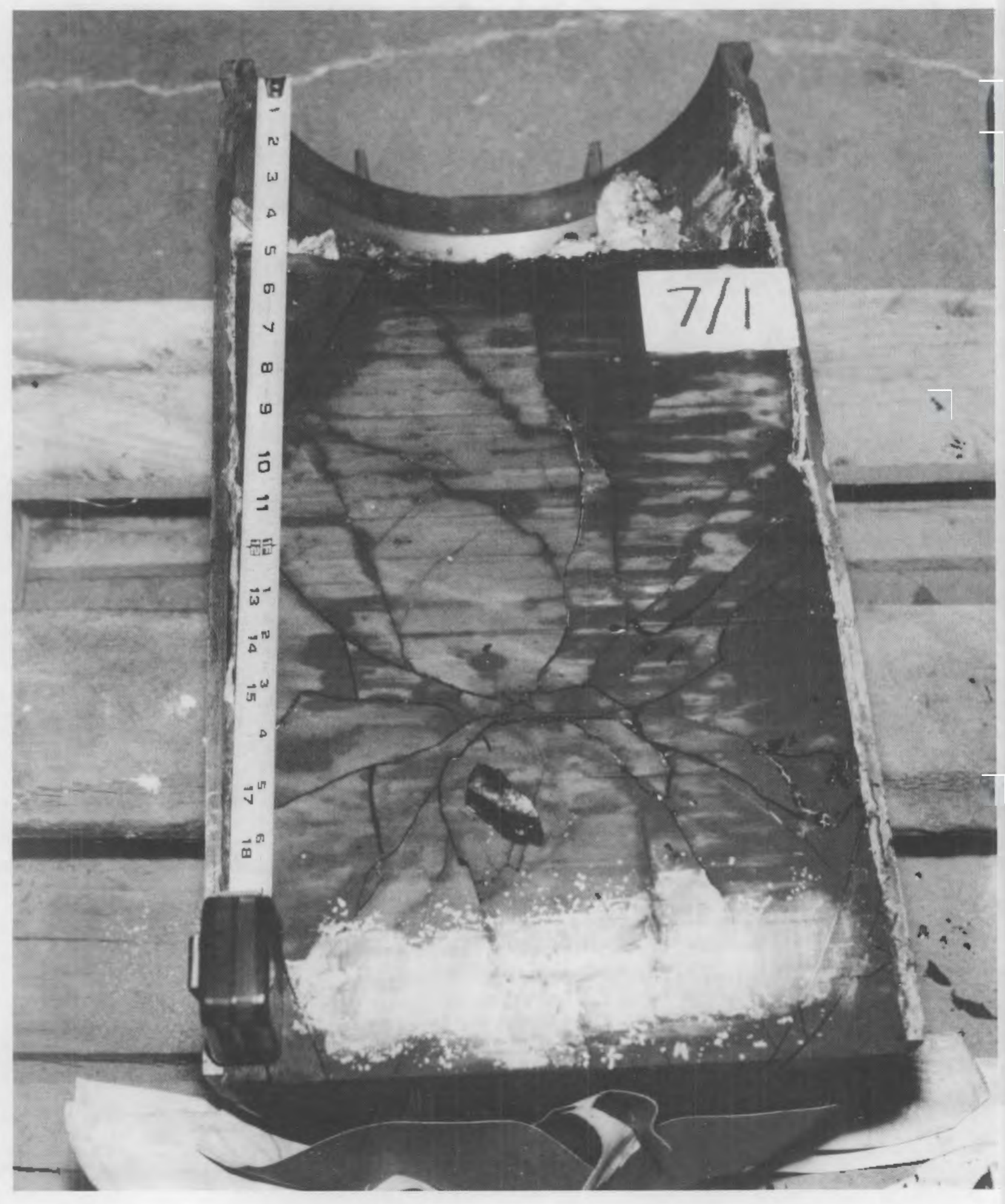

FIGURE B.7. Canister \#7, Part $1(7 / 1)$ 


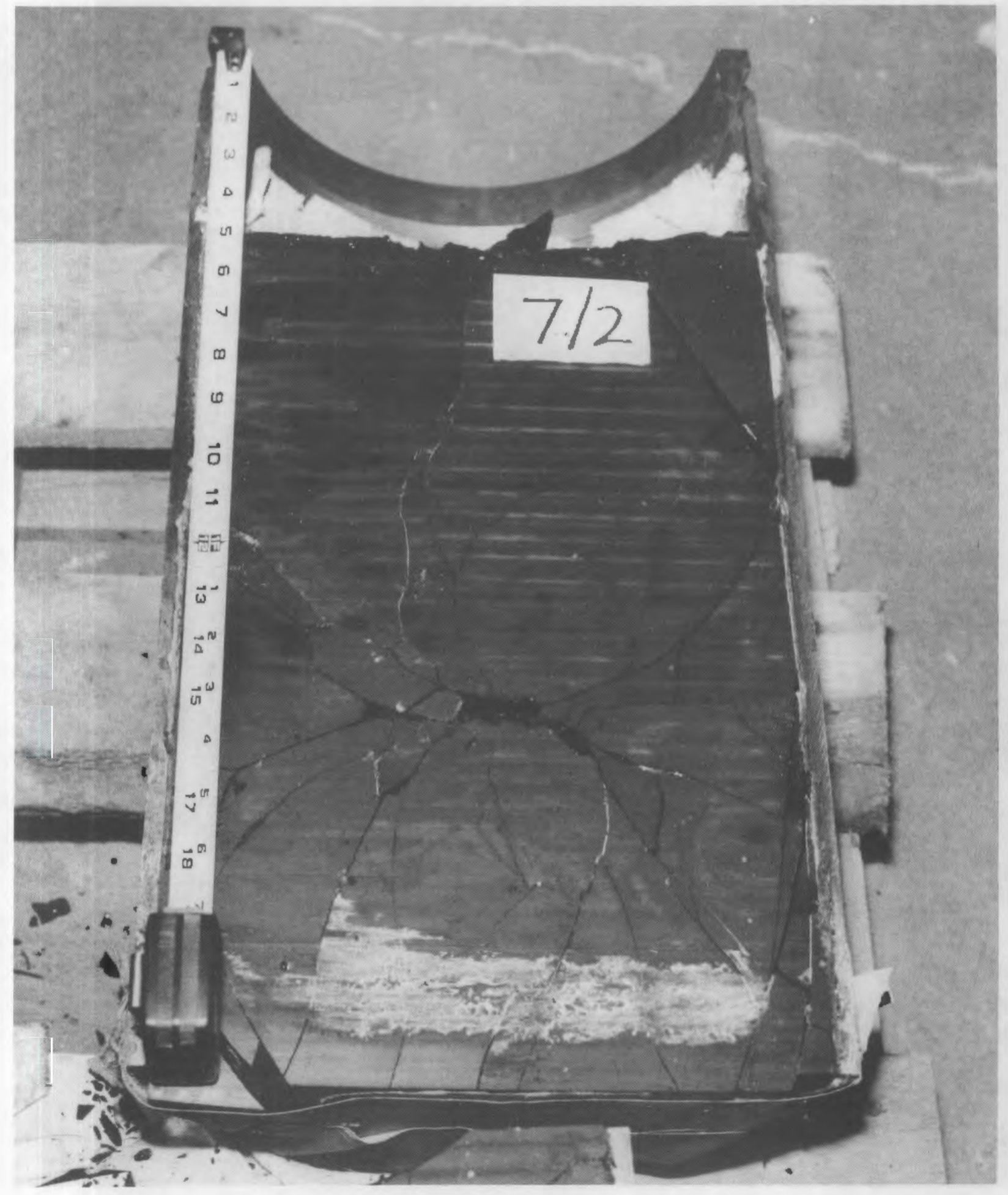

FIGURE 8.8. Canister \#7, Part $2(7 / 2)$ 


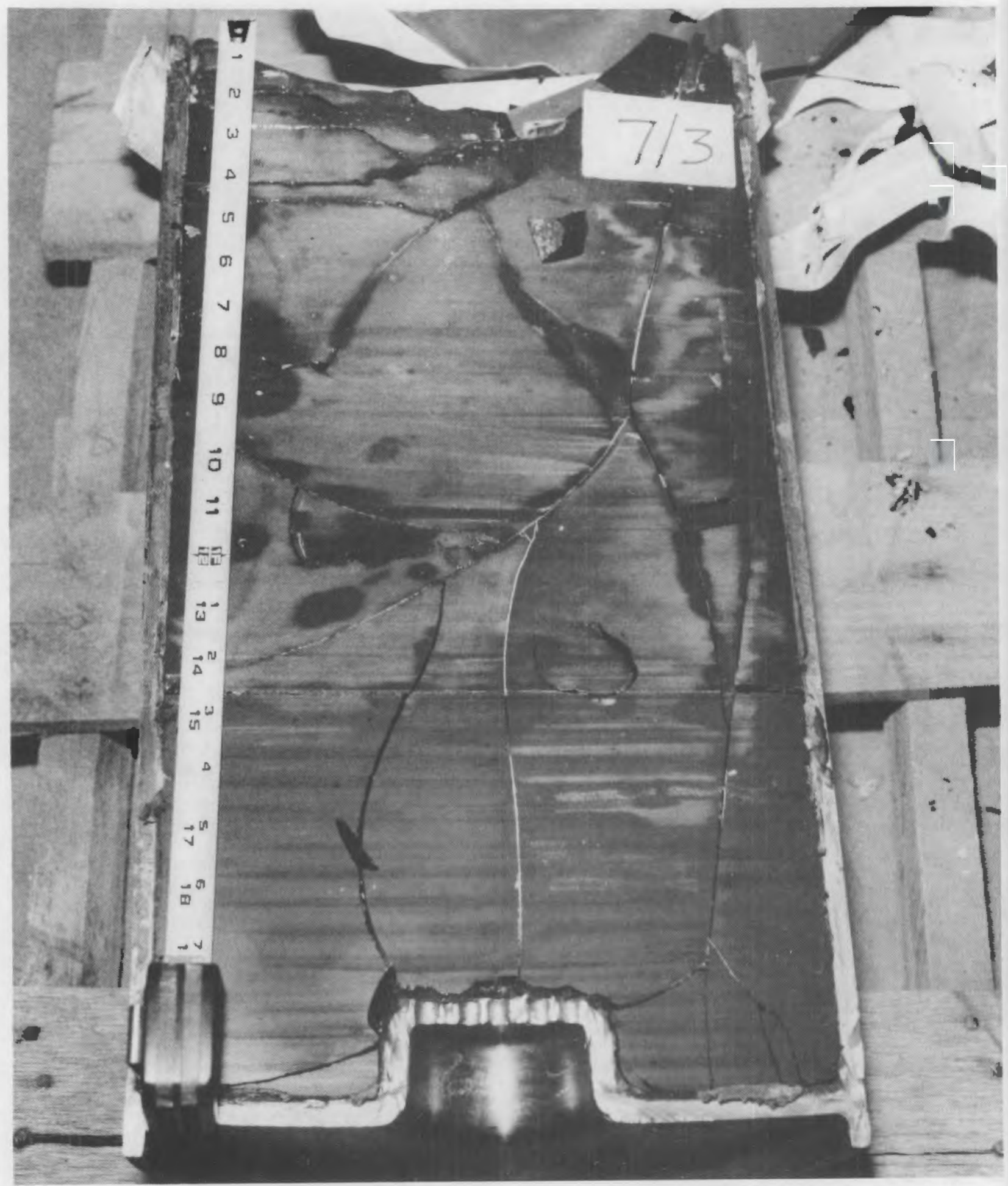

FIGURE B.9. Canister $\# 7$, Part $3(7 / 3)$ 


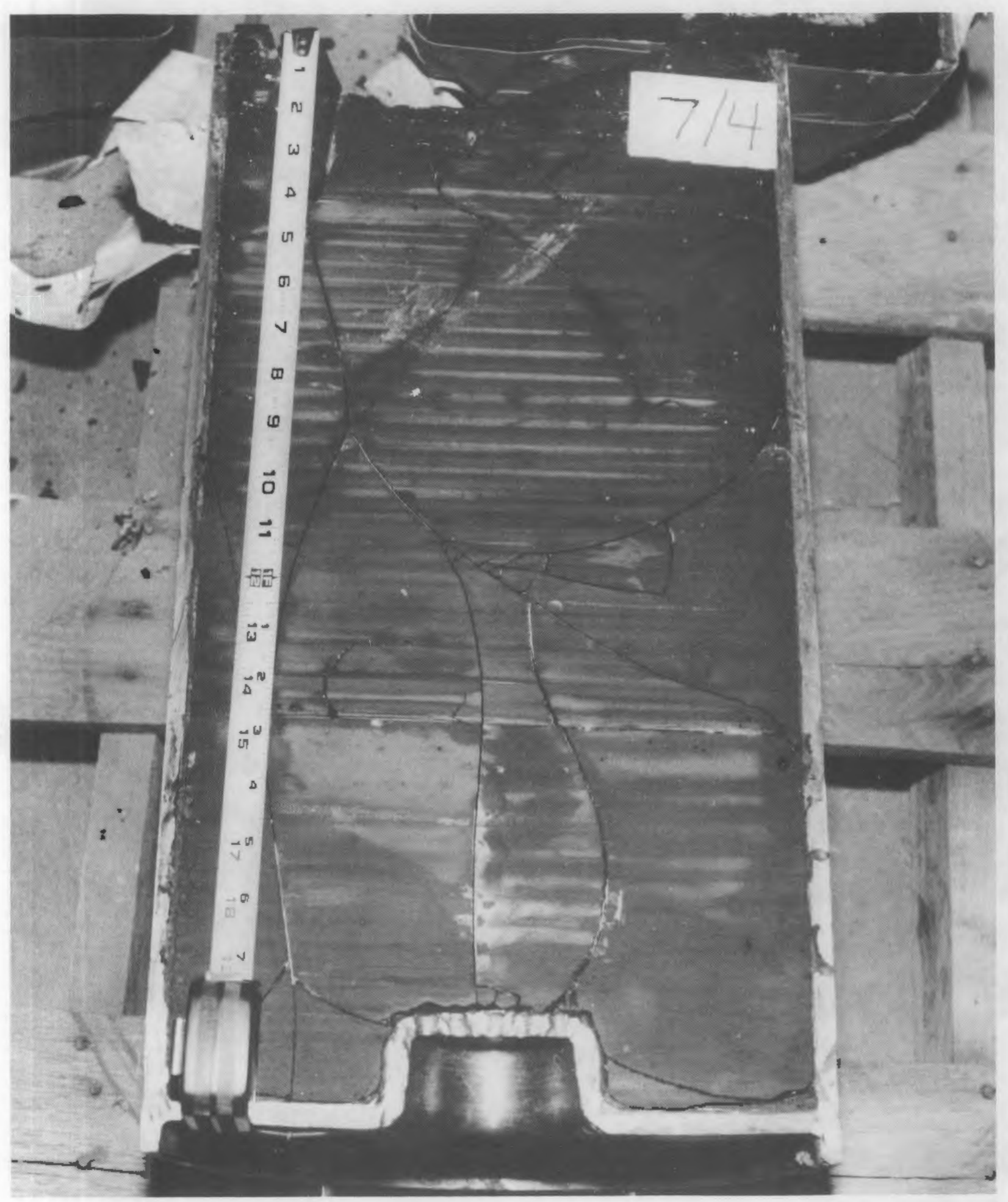

FIGURE B.10. Canister \#7, Part $4(7 / 4)$ 


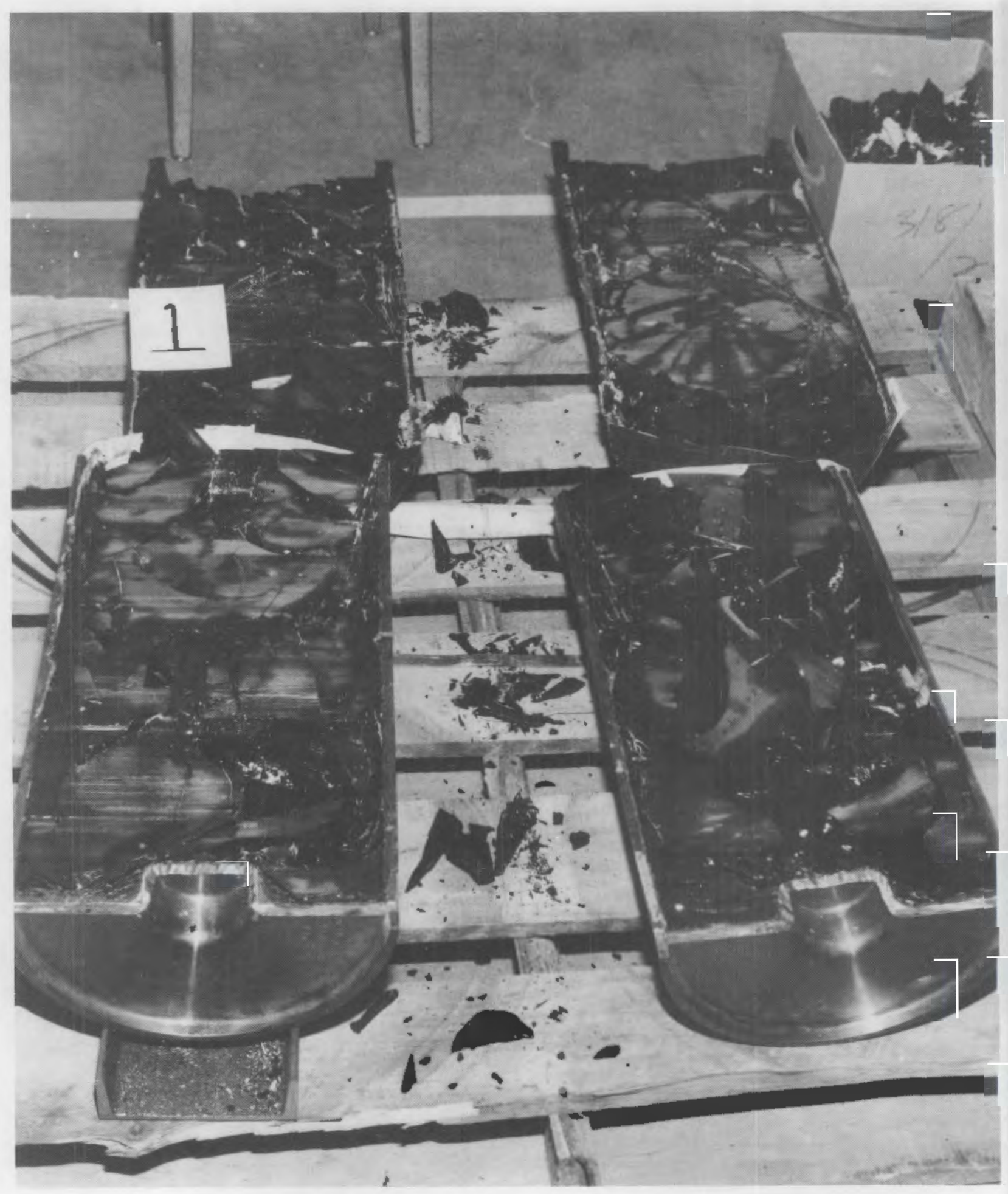

FIGURE B.11. Canister \#1 


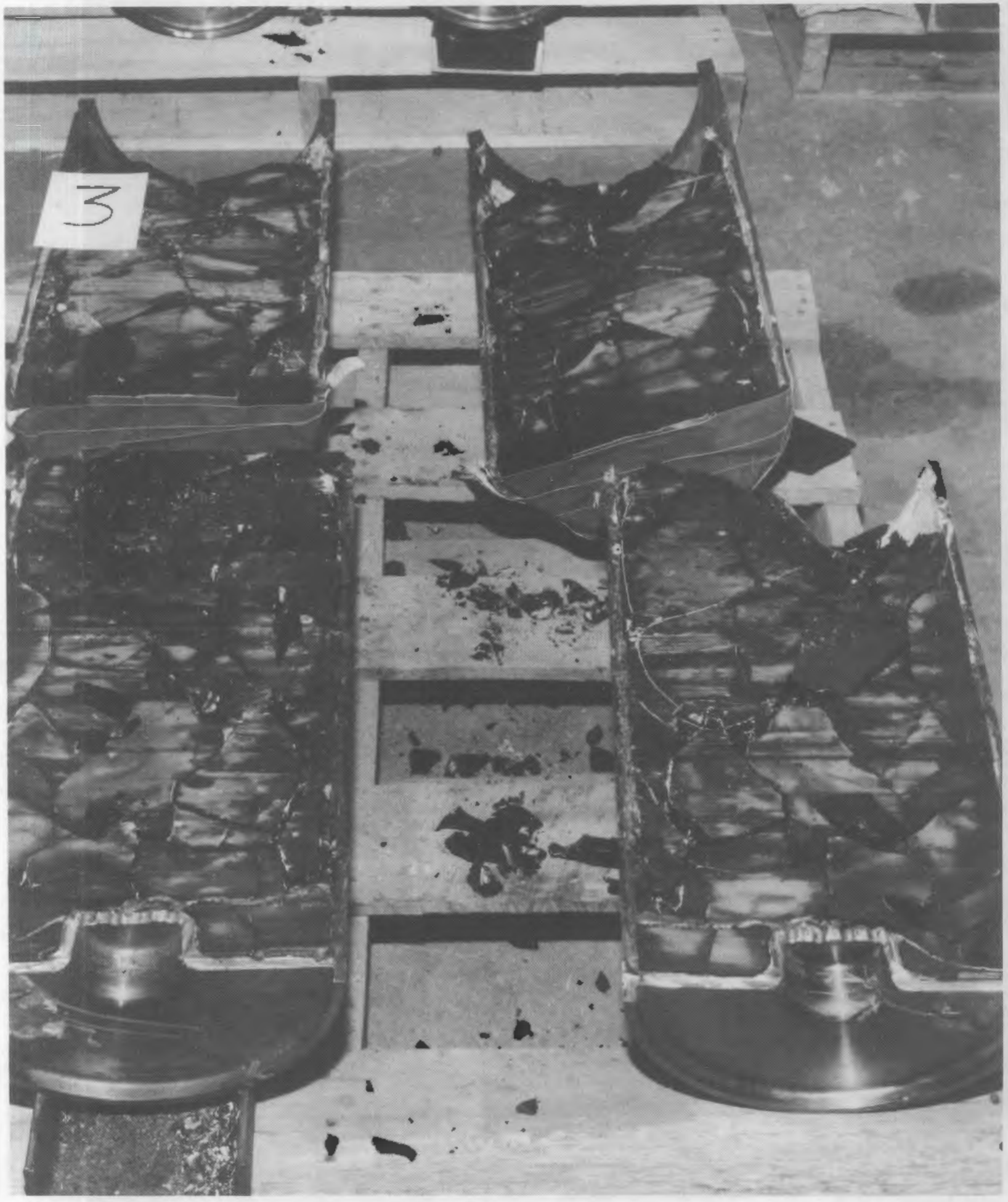

FIGURE B.12. Canister \#3 


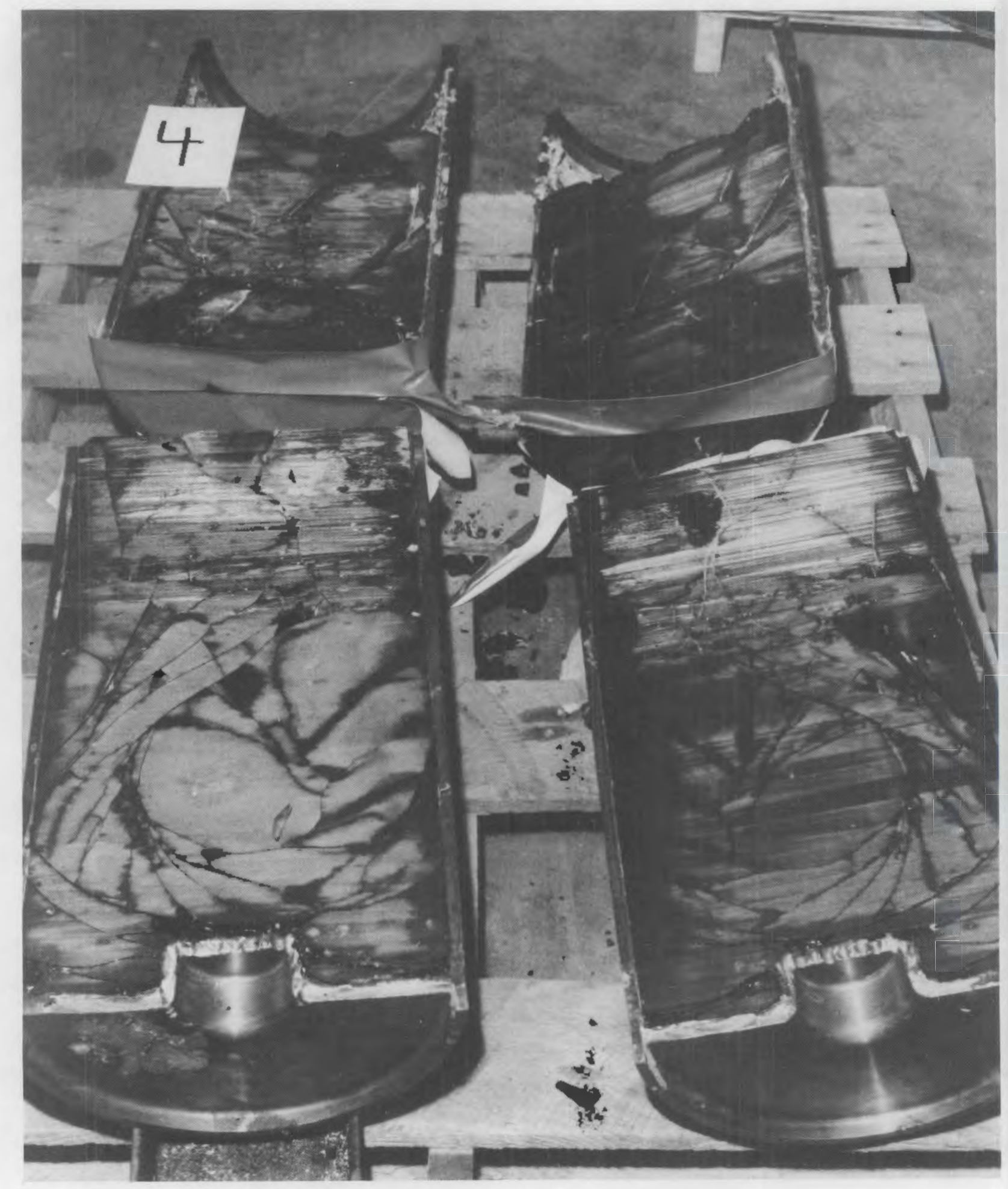

FIGURE B.13. Canister \#4 


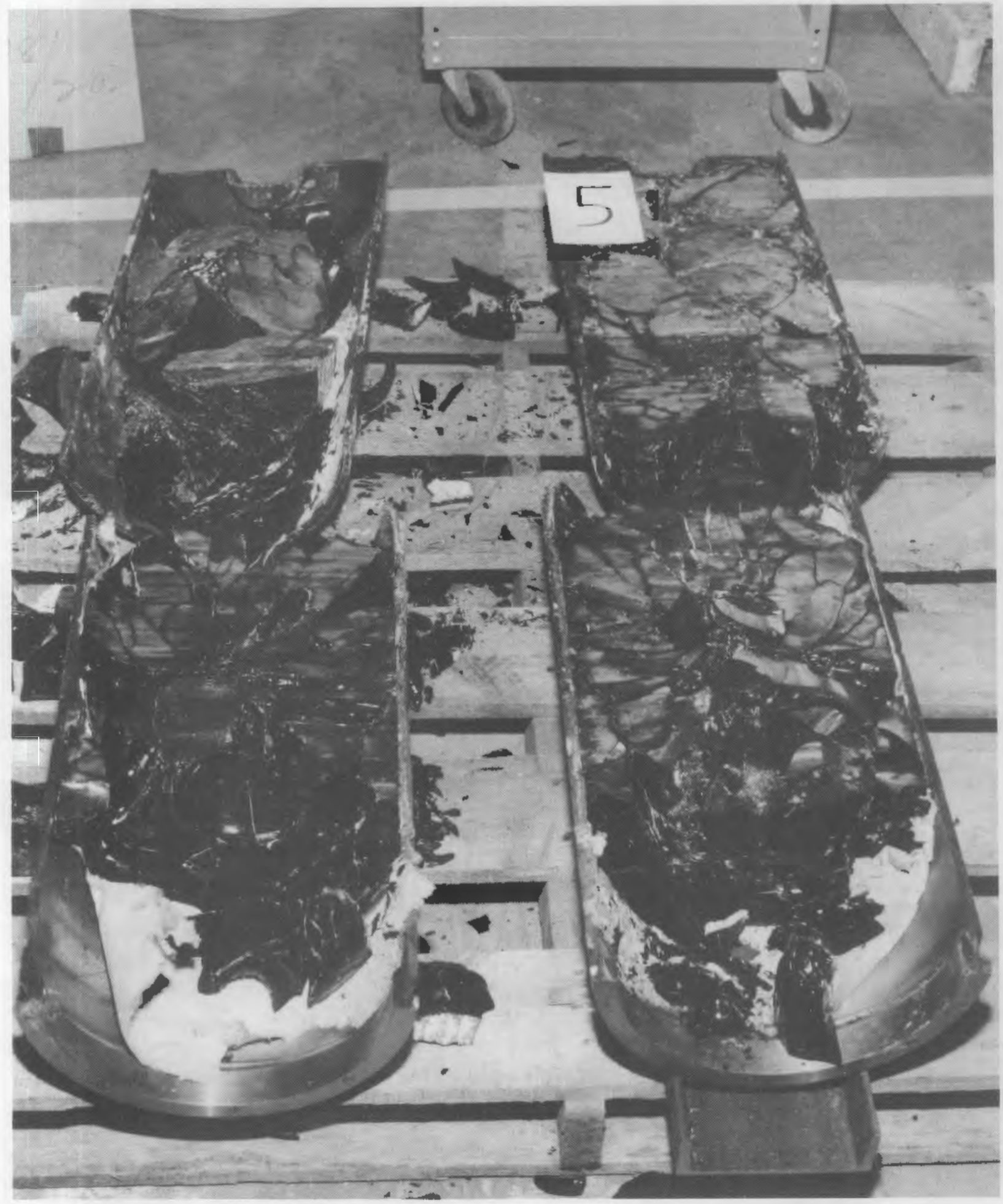

FIGURE B.14. Canister \#5 


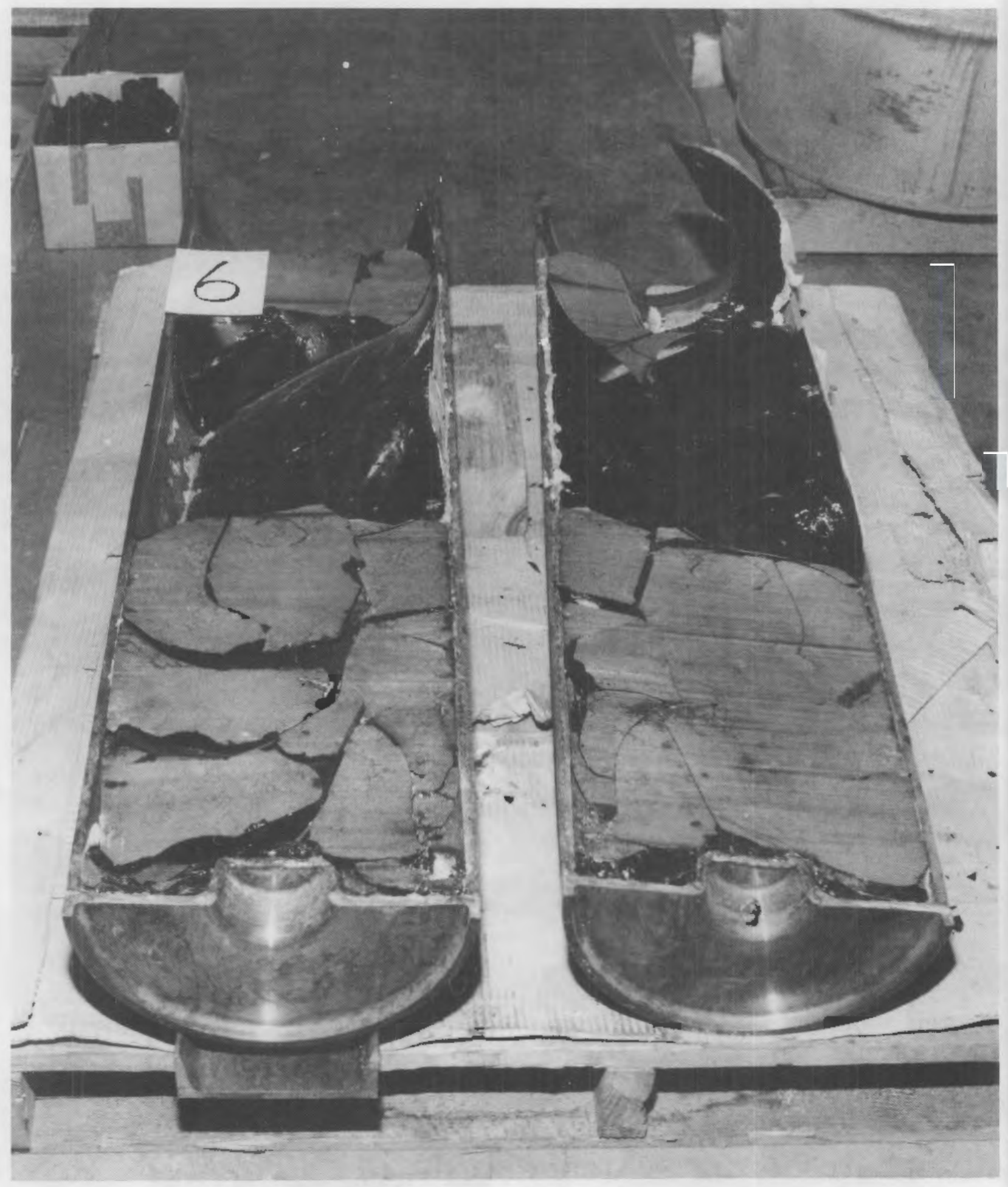

FIGURE B.15. Canister \#6 


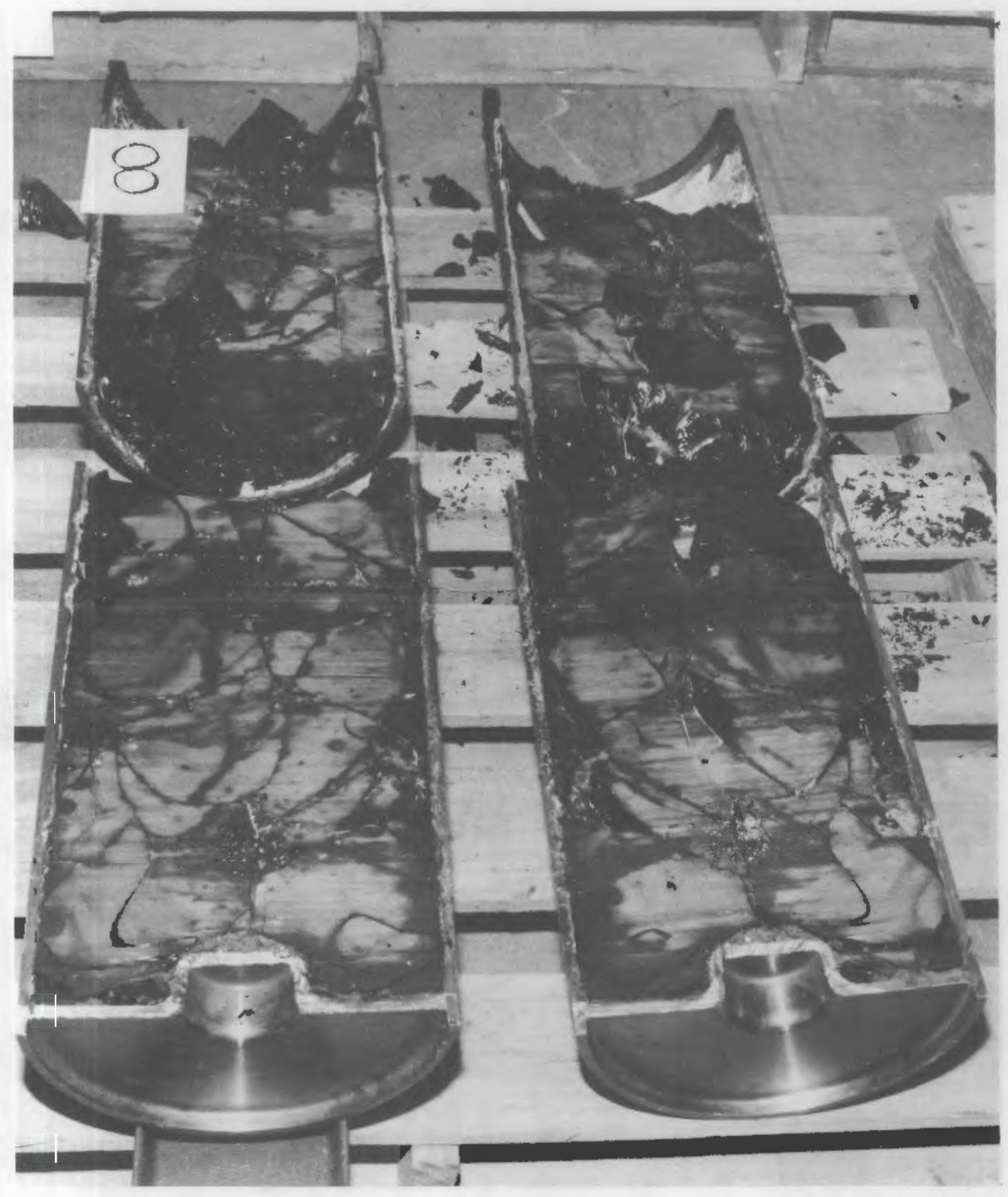

FIGURE B.16. Canister \#8 


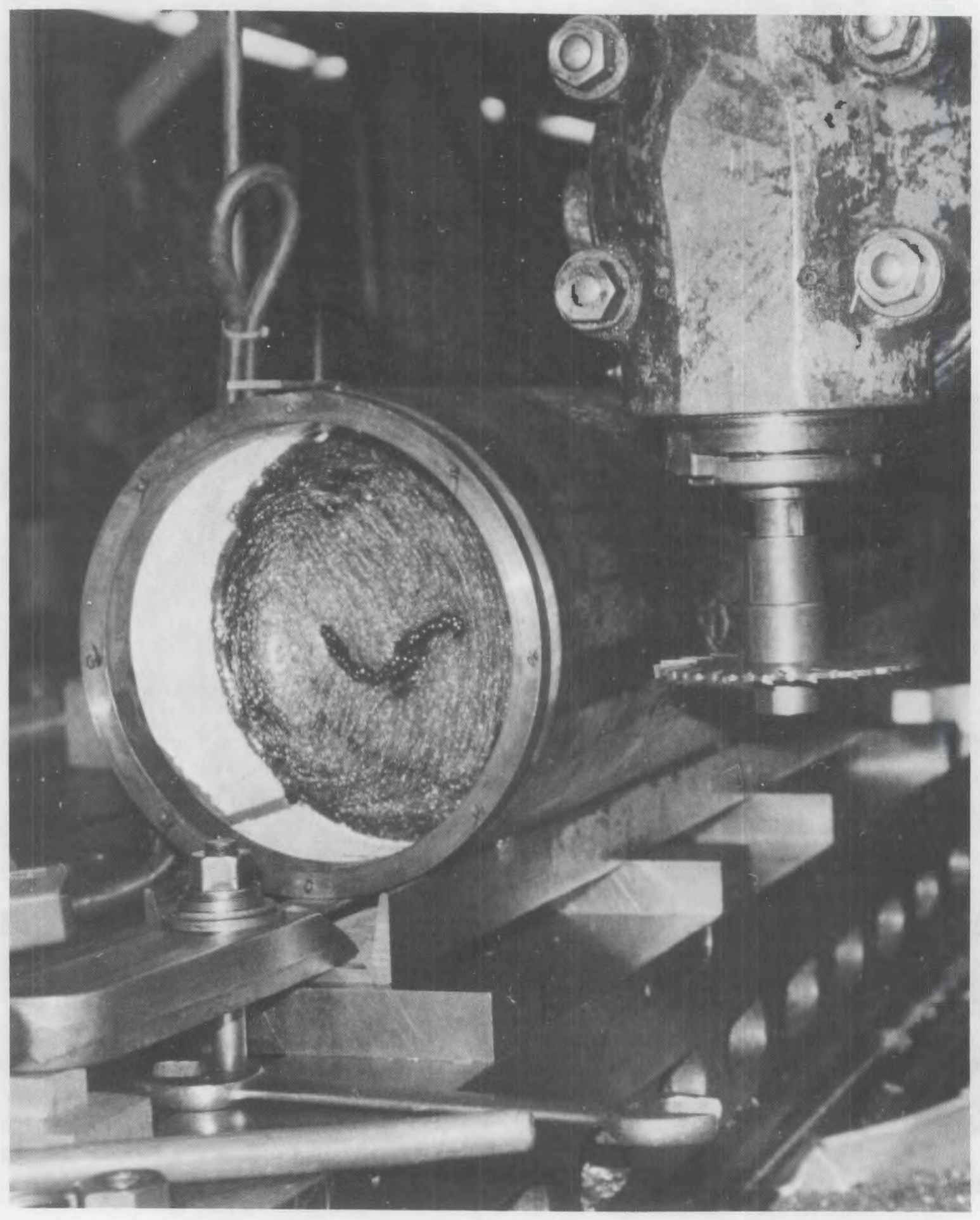

FIGURE B.17. Canister Cutting 


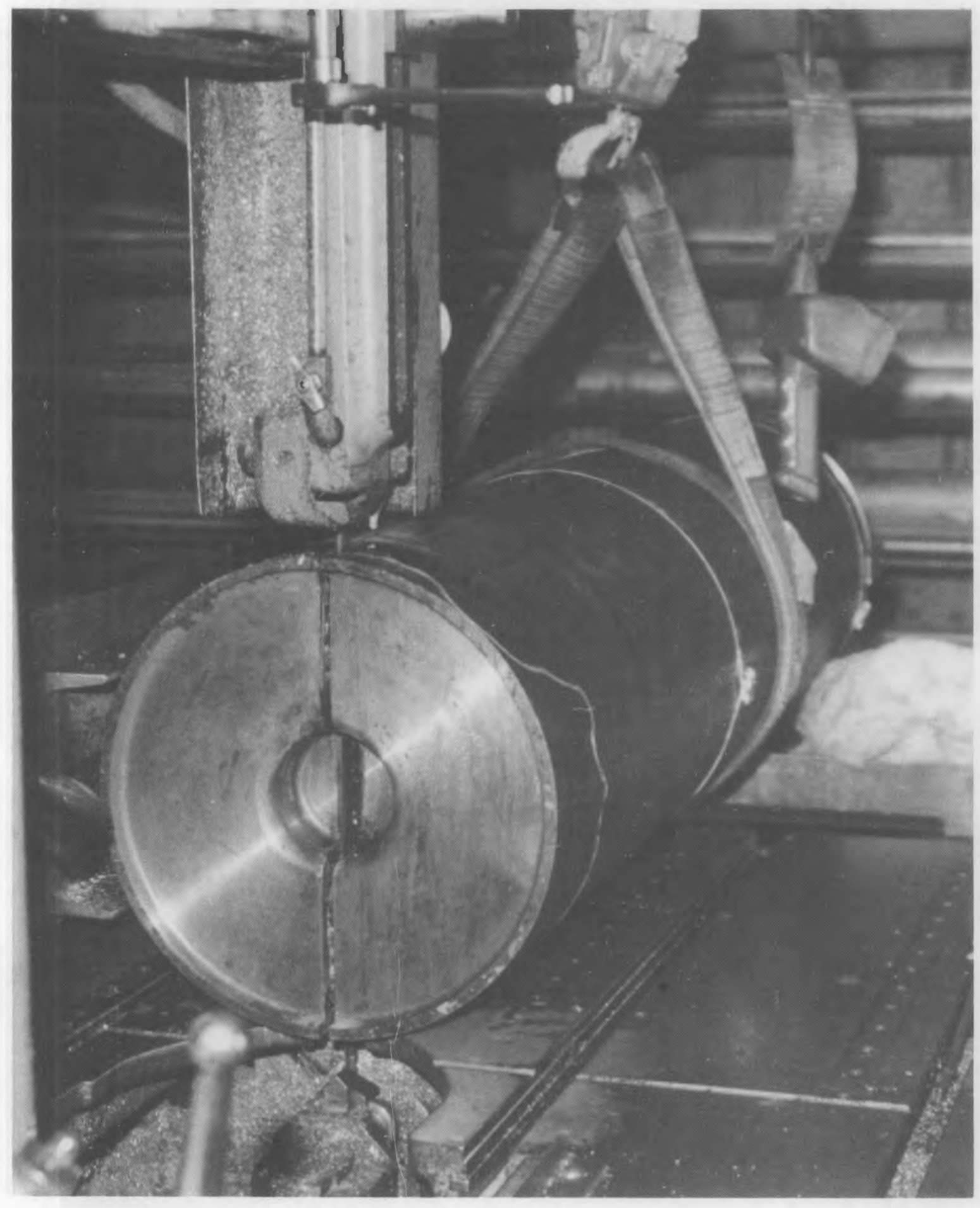

FIGURE B.18. Glass Cutting 


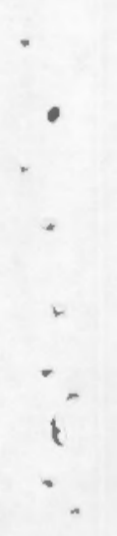




\section{DISTRIBUTION}

No. of

Copies

OFFSITE

30

\section{DOE Technical Information Center}

6 Geologic Repository Division DOE Office of Civilian Radioactive Waste Management Forrestal Building Washington, DC 20585

ATTN: C. R. Cooley, RW-4

J. R. Hilley

W. J. Purcel1, RW-20

B. C. Rusche, RW-1

D. E. Shelor

R. Stein, RW-23

3 DOE Office of Defense Waste \& Byproducts Management GTN

Washington, OC 20545

ATTN: R. K. Heusser

J. E. Lyt le, DP-12

R. D. Walton, $\mathrm{Jr}$., DP -123

6 DOE Office of Terminal Waste Disposal \& Remedial Action GTN

Washington, DC 20545

ATTN: J. A. Coleman, NE-25

T. W. MCIntosh, NE-25

H. Stelling, NE-25

W. R. Voigt, NE-20

H. F. Walter, $N E-25$

J. B. Zorn, NE-25

A. T. Clark

Division of Fuel Material Safety

Nuclear Regulatory Comnission Washington, DC 20555
No. of

Copies

G. L. Sjoblom

Environmental Protection Agency Office of Radiation Programs

401 M Street, S.W.

Washington, DC 20460

J. M. McGough

DOE Albuquerque Operations Office

P.0. Box 5400

Albuquerque, NM 87185

P. G. Hagen

Joint Integration office

Bidg. 3, 2nd Floor

2201 San Pedro N.E.

Albuquerque, NM 87110

E. Maestas

DOE West Valley Operations Office

P.0. Box 191

West Valley, NY 14171

2 DOE Idaho Dperations Office

550 Second Street

Idaho Falls, ID 83401

ATTN: M. J. Barainca

J. P. Hamric

F. T. Fong

DOE San Francisco Operations

1333 Broadway

0akland, CA 94612

M. R. Jugan

DOE Oak Ridge Dperations Office P.0. Box E

Oak Ridge, TN 37830

W. J. Brumley

DOE Savannah River Operations Office

P.0. Box A

Aiken, SC 29801 
No. of

Copies

V. Stello

Office of the Executive

Director for Operations

Mail Station 6209

Nuclear Regulatory Commission

Washington, DC 20555

4 Sandia Laboratories

P.0. Box 5800

Albuquerque, NM 87185

ATTN: D. R. Anderson

R. W. Lynch

W. Weart

Technical Library

B. D. Shipp

Battelle Memorial Institute

Office of Crystalline

Repository Development

9800 South Cass Avenue

Argonne, IL 60439

3 Battelle Memorial Institute Project Management Division 505 King Avenue

Columbus, $\mathrm{OH} \quad 43201$

ATTN: W. A. Carbeiner

W. S. Madia

B. Rawless

F. Holzer

Lawrence Livermore National Laboratory

University of California

P. 0 . Box 808

Livermore, CA 94550

D. T. 0akley, MS 671

Los Alamos Scientific Laboratory

P.0. Box 1663

Los Alamos, NM 87544

4 Oak Ridge National Laboratory

P.0. Box $Y$

Oak Ridge, TN 37830

ATTN: J. 0. Blomeke

W. D. Burch
No. of

Copies

Oak Ridge National Laboratory

(contd)

ATTN: R. T. Jubin

L. J. Mezga

M. J. Steindler

Argonne National Laboratory

9700 South Cass Avenue

Argonne, IL 60439

C. S. Abrams

Argonne National Laboratory

P.0. Box 2528

Idaho Falls, ID 83401

J. R. Berreth

Westinghouse Idaho Nuclear Co., Inc.

P. 0 . Box 4000

Idaho Falls, ID 83401

7 E. I. du Pont de Nemours Company

Savannah River Laboratory

Aiken, SC 29801

ATTN: M. D. Boersma

J. G. Glasscock

E. J. Hennelly

C. M. Jantzen

J. R. Knight

M. J. Plodinec

C. T. Randall

E. A. Jennrich

EG\&G Idaho

P.0. Box 1625

Idaho Falls, ID 83415

R. Williams

Electric Power Research

Institute

3412 Hillview Avenue

P.0. Box 10412

Palo Alto, CA 94304 
No. of

Copies

7 West Valley Nuclear Services Company

P.0. Box 191

West Valley, NY 14171

ATTN: C. C. Chapman

J. C. Cwynar

J. E. Krauss

S. J. Marchette

J. M. Pope

L. R. Eisenstatt

S. M. Barnes

J. L. Larocca, Chairman

Energy Research \& Development Authority

Empire State Plaza

Albany, NY 12223

ONSITE

9 DOE Richland Operations Office

J. H. Ant tonen

E. A. Bracken

G. J. Bracken

C. R. DeLannoy

R. D. Izatt

N. T. Karagianes

J. L. Rhoades

M. W. Shupe

J. D. White

14 Rockwell Hanford Operations

R. N. Gurley

J. M. Henderson

T. H. May

H. E. McGuire

J. L. Nelson

R. D. Prosser

I. E. Reep

G. L. Scott

D. A. Turner

T. B. Venziano

D. D. Wodrich

R. D. Wojtasek

B. A. Wolfe

File Copy
No. of

Copies

UNC United Nuclear Industries

T. E. Dabrowski/W. J. Kyriazis

2 Westinghouse Hanford Company.

R. E. Lerch

J. D. Watrous

113 Pacific Northwest Laboratory

C. R. Allen

R. P. Allen

W. W. Ballard, Jr.

S. D. Bates

H. T. Blair

W. F. Bonner

R. A. Brouns (2)

G. H. Bryant (2)

J. L. Buelt

H. C. Burkholder (10)

J. R. Carrell (2)

D. G. Coles

L. J. Ethridge (1D)

D. W. Faletti (25)

R. K. Farnsworth

V. F. Fitzpatrick

H. A. Haerer

M. S. Hanson

L. K. Holton

J. H. Jarrett

D. E. Knowlton

S. S. Koegler

M. R. Kreiter

W. L. Kuhn

W. W. Laity

L. T. Lakey (2)

D. E. Larson

J. M. Latkovich

S. F. Liebetrau

E. E. McClanahan

J. L. MCEl roy

G. B. Mellinger

J. E. Mendel

J. E. Minor (2)

S. T. Mitchell

R. N. Nakaoka

J. M. Perez, Jr. 
No. of

Copies

R. D. Peters (3)

M. E. Peterson

A. M. Platt

J. A. Powell

B. A. Pulsipher

M. A. Reimus

P. W. Reimus

J. T. A. Roberts

W. A. Ross (2)

K. J. Schneider
No. of

Copies

P. A. Scott

G. J. Sevigny

D. H. Siemens

R. L. Skaggs

S. C. Slate (3)

J. L. Straalsund

J. H. Westsik, Jr.

Publishing Coordination (2)

Technical Information (5) 